U.S. Department of Energy

Energy Efficiency

and Renewable Energy

Bringing you a prosperous future where energy

is clean, abundant, reliable, and affordable

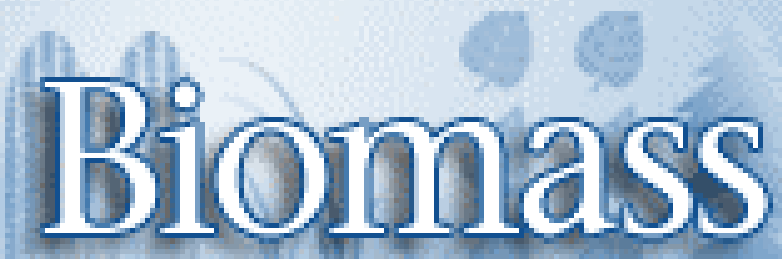

\title{
Top Value Added Chemicals from Biomass Volume I-Results of Screening for Potential Candidates from Sugars and Synthesis Gas
}

Produced by the Staff at

Pacific Northwest National Laboratory (PNNL) National Renewable Energy Laboratory (NREL) Office of Biomass Program (EERE) For the Office of the Biomass Program

T. Werpy and G. Petersen, Editors 


\section{Top Value Added Chemicals From Biomass}

\section{Volume I: Results of Screening for Potential Candidates from Sugars and Synthesis Gas}

Produced by Staff at the Pacific Northwest National Laboratory (PNNL) and the National Renewable Energy Laboratory (NREL)

T. Werpy and G. Petersen, Principal Investigators

Contributing authors: A. Aden and J. Bozell (NREL); J. Holladay and J. White (PNNL); and Amy Manheim (DOE-HQ)

Other Contributions (research, models, databases, editing): D. Elliot, L. Lasure, S. Jones and M. Gerber (PNNL); K. Ibsen, L. Lumberg and S. Kelley (NREL) 


\begin{abstract}
Acknowledgement: The authors gratefully acknowledge the support and assistance from NREL staff members S. Bower, E. Jarvis, M. Ruth, and A. Singh and review by Paul Stone and Mehmet Gencer, independent consultants from the chemical industry as well as specific input and reviews on portions of the report by T. Eggeman of Neoterics International and Brian Davison of Oak Ridge National Laboratory.
\end{abstract}

\begin{abstract}
NOTICE
This report was prepared as an account of work sponsored by an agency of the United States government. Neither the United States government nor any agency thereof, nor any of their employees, makes any warranty, express or implied, or assumes any legal liability or responsibility for the accuracy, completeness, or usefulness of any information, apparatus, product, or process disclosed, or represents that its use would not infringe privately owned rights. Reference herein to any specific commercial product, process, or service by trade name, trademark, manufacturer, or otherwise does not necessarily constitute or imply its endorsement, recommendation, or favoring by the United States government or any agency thereof. The views and opinions of authors expressed herein do not necessarily state or reflect those of the United States government or any agency thereof.
\end{abstract}

Available electronically at http://www.osti.gov/bridge

Available for a processing fee to U.S. Department of Energy and its contractors, in paper, from:

U.S. Department of Energy

Office of Scientific and Technical Information

P.O. Box 62

Oak Ridge, TN 37831-0062

phone: 865.576.8401

fax: 865.576.5728

email: mailto:reports@adonis.osti.gov

Available for sale to the public, in paper, from:

U.S. Department of Commerce

National Technical Information Service

5285 Port Royal Road

Springfield, VA 22161

phone: 800.553 .6847

fax: 703.605 .6900

email: orders@ntis.fedworld.gov

online ordering: http://www.ntis.gov/ordering.htm 


\section{Table of Contents}

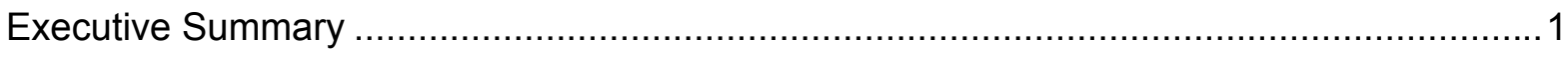

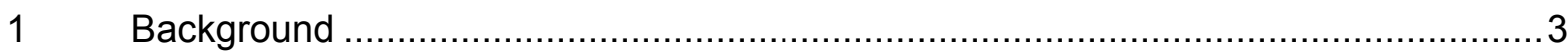

2 Objective

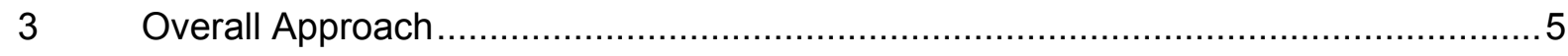

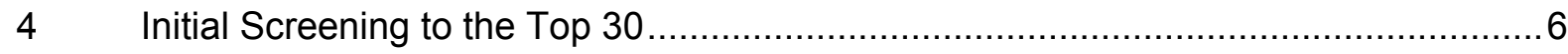

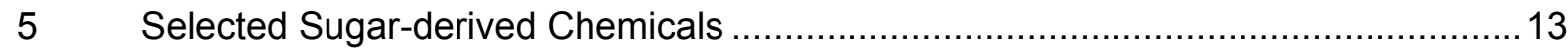

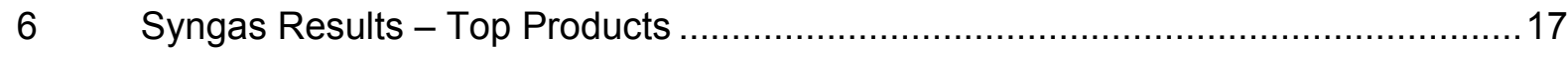

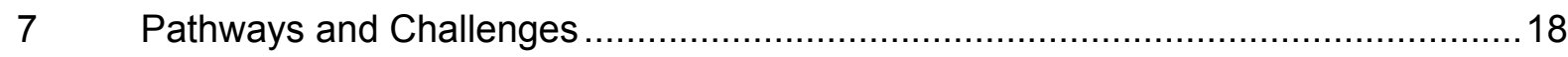

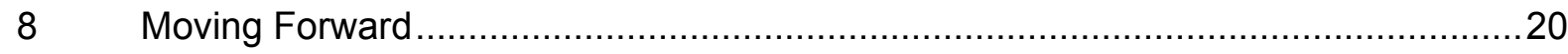

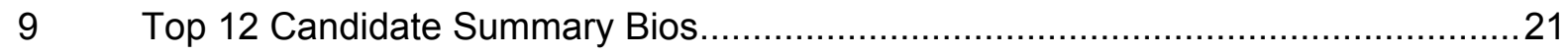

9.1 Four Carbon 1,4-Diacids (Succinic, Fumaric, and Malic) ……………............22

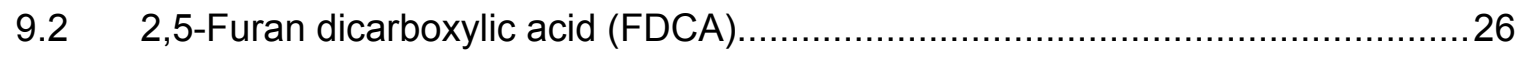

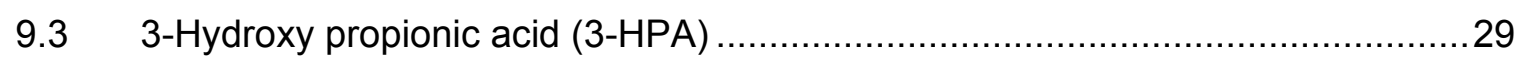

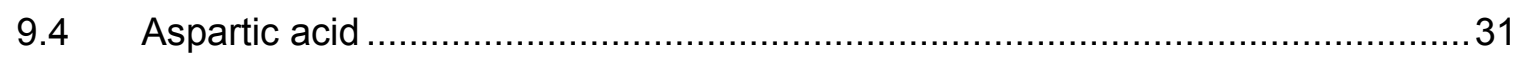

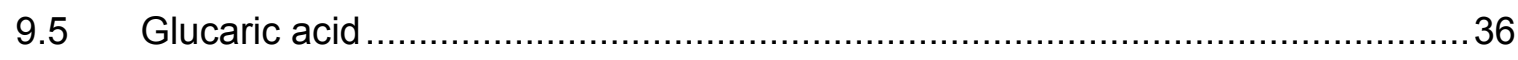

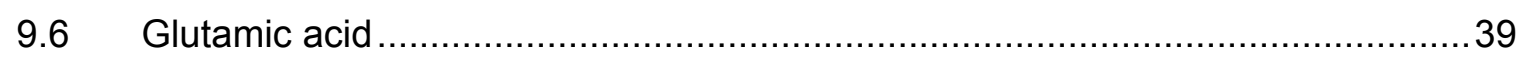

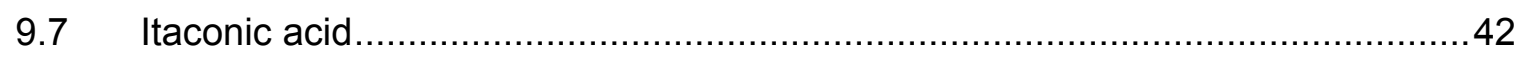

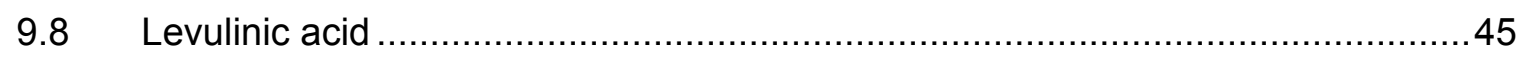

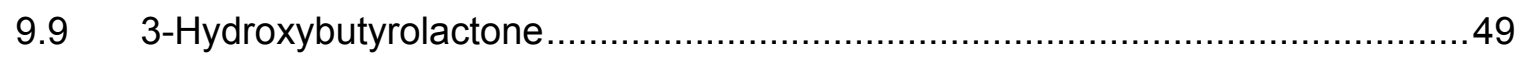

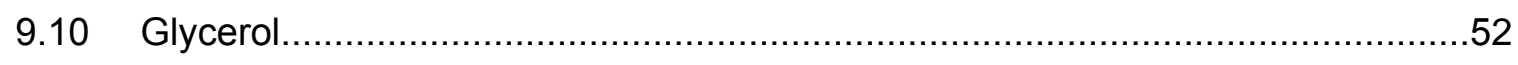

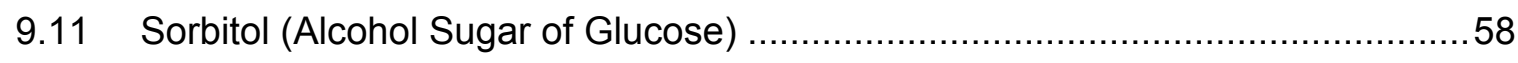

9.12 Xylitol/arabinitol (Sugar alcohols from xylose and arabinose) ..........................61

10 Catalog of Potential Chemicals and Materials from Biomass ..................................65 


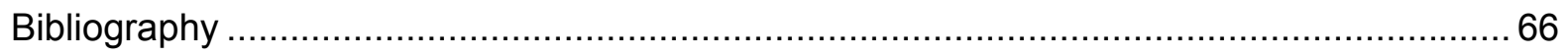

References Used to Develop Catalog for Potential Biobased Products ........................66

References for Assigning Chemical and Biochemical Pathways ..................................66

\section{Tables}

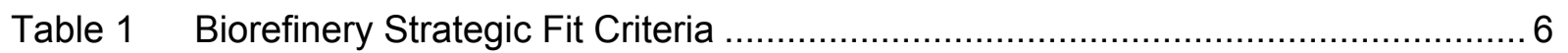

Table 2 Top Candidates from the First Screen ………........................................... 8

Table 3 Down Selection - Top 30 Results ............................................................. 12

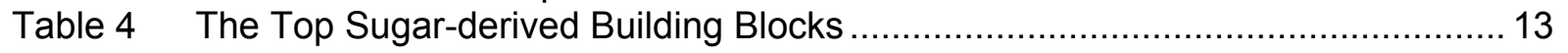

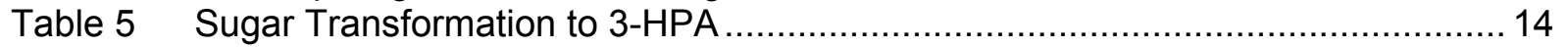

Table 6 Reductive Transformation - 3HP to 1,3 PDO via catalytic dehydrogenation ........ 14

Table 7 Dehydrative Transformation - 3-HPA to acrylic acid via catalytic dehydration .... 14

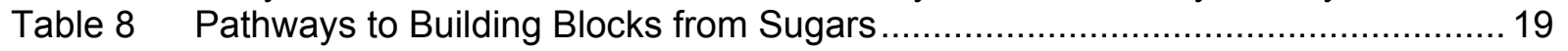

Table 9 Pathways to Building Block From Sugars [Four Carbon 1,4 Diacids

(Succinic, Fumaric, and Malic] ............................................................... 22

Table 10 Family 1: Reductions [Primary Transformation Pathway(s) to Derivatives Four

Carbon 1,4-Diacids (Succinic, Fumaric, and Malic)] ....................................... 22

Table 11 Family 2: Reductive Aminations [Primary Transformation Pathway(s) to

Derivatives - Four Carbon 1,4-Diacids (Succinic, Fumaric, and Malic)] .............. 22

Table 12 Family 3: Direct Polymerization [Primary Transformation Pathway(s) to

Derivatives - Four Carbon 1,4-Diacids (Succinic, Fumaric, and Malic] ...............2 23

Table 13 Pathways to Building Block From Sugars [ 2,5-Furan dicarboxylic Acid (FDCA)] 26

Table 14 Family 1: Reduction [Primary Transformation Pathway(s) to Derivatives:

2,5-Furan dicarboxylic Acid (FDCA)] ..................................................... 26

Table 15 Family 2: Direct Polymerization [Primary Transformation Pathway(s) to Derivatives: 2,5-Furan dicarboxylic Acid (FDCA)] ……………………….... 27

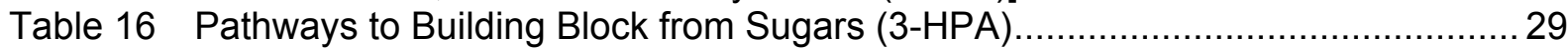

Table 17 Family 1: Reductions [Primary Transformation Pathway(s) to

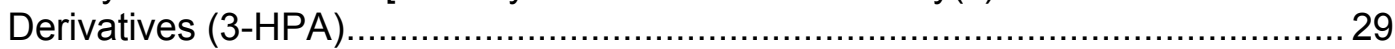

Table 18 Family 2: Dehydration [Primary Transformation Pathway(s) to

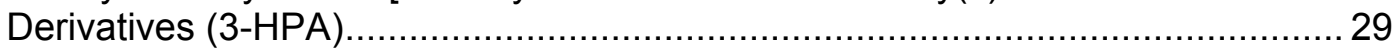

Table 19 Pathways to Building Block - Aspartic Acid ................................................... 31

Table 20 Family 1: Reductions [Primary Tansformation Pathway(s) to Derivatives Aspartic Acid ................................................................................ 32

Table 21 Family 2: Dehydration - [Primary Tansformation Pathway(s) to Derivatives Aspartic Acid] ................................................................................. 32

Table 22 Family 3: Direct Polymerization [Primary Tansformation Pathway(s) to Derivatives - Aspartic Acid...................................................................... 32

Table 23 Pathway to Building Block From Sugars [Glucaric Acid] .................................. 36

Table 24 Family 1 - Dehydration [Primary Transformation Pathway(s) to Derivatives -

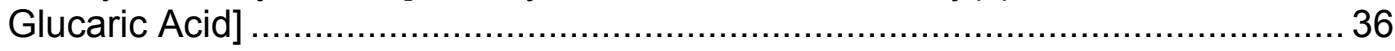

Table 25 Amination and Direct Polymeriation [Primary Transformation Pathway(s) to Derivatives - Glucaric Acid] 
Table 26 Pathways to Building Block From Sugars [Glutamic Acid]....

Table 27 Family 1: Reductions [Primary Transformation Pathway(s) to Derivatives -

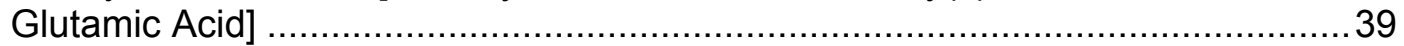

Table 28 Pathways to Building Block from Sugars [Itaconic Acid] .................................42

Table 29 Family 1: Reductions [ Primary Transformation Pathway(s) to Derivatives Itaconic Acid] ....................................................................................... 42

Table 30 Family 2: Direct Polymerization [ Primary Transformation Pathway(s) to Derivatives - Itaconic Acid] ................................................................... 42

Table 31 Pathways to Building Block From Sugars [Levulinic Acid] ...............................45

Table 32 Family 1: Reductions [Primary Transformation Pathways(s) to Derivatives -

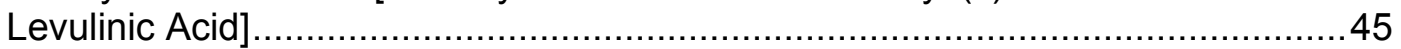

Table 33 Family 2: Oxidations [Primary Transformation Pathways(s) to Derivatives Levulinic Acid] ...................................................................................... 45

Table 34 Family 3: Condensation [Primary Transformation Pathways(s) to Derivatives Levulinic Acid] ................................................................................ 46

Table 35 Pathways to Building Block from Sugars [Pathways to Building Block From Sugars - 3-Hydroxybutyrolactone] .............................................................. 49

Table 36 Family 1: Reductions [Primary Transformation Pathway(s) to Derivatives 3-Hydroxybutyrolactone] ............................................................................ 49

Table 37 Family 2: Direct Polymerization [Pimary Transformation Pathway(s) to

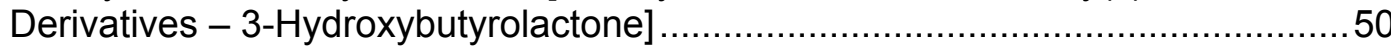

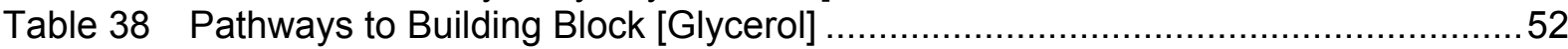

Table 39 Family 1: Oxidation [Primary Transformation Pathway(s) to

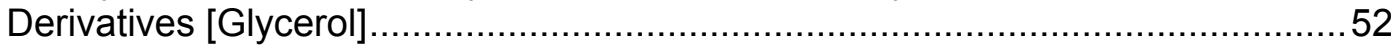

Table 40 Family 2: Bond Breaking (Hydrogenolysis) [Primary Transformation Pathway(s) to Derivatives [Glycerol].

Table 41 Family 3: Direct Polymerization [Primary Transformation Pathway(s) to

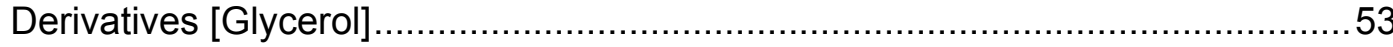

Table 42 Preliminary Economic Screening of the Glycerol Potential...............................56

Table 43 Preliminary Economic Screening of the Glycerol Potential (Continued) ...............57

Table 44 Pathways to Building Block [Sorbitol] ........................................................58

Table 45 Family 1: Dehydration [Primary Transformation Pathway(s) to Derivatives -

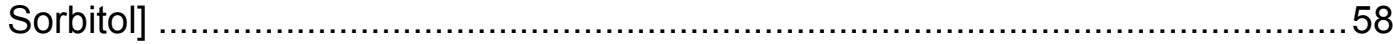

Table 46 Family 2: Bond Cleavage (hydrogenolysis) [Primary Transformation Pathway(s)

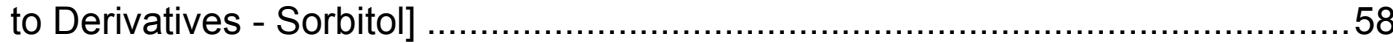

Table 47 Family 3: Direct Polymerization [Primary Transformation Pathway(s) to

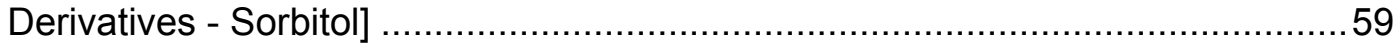

Table 48 Pathways to Building Block From Sugars [ Xylitol/arabinitol]...........................61

Table 49 Family 1: Oxidations [Primary Transformation Pathway(s) to Derivatives Xylitol/arabinitol] ..................................................................................... 61

Table 50 Family 2: Bond Cleavage (hydrogenolysis) [Primary Transformation Pathway(s)

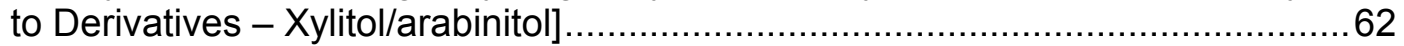

Table 51 Family 2: Direct Polymerization [Primary Transformation Pathway(s) to Derivatives - Xylitol/arabinitol].... 


\section{Figures}

Figure 1 Visual Representation of Overall Selection Strategy...................................... 5

Figure 2 An Example of a Flow-Chart for Products from Petroleum-based Feedstocks .... 10

Figure 3 Analogous Model of a Biobased Product Flow-chart for Biomass Feedstocks .... 11

Figure 4 Star Diagram of 3-Hydroxypropionic Acid ................................................ 15

Figure 5 Succinic Acid Chemistry to Derivatives ...................................................... 23

Figure 6 Simplified PFD of Glucose Fermentation to Succinic Acid ............................. 24

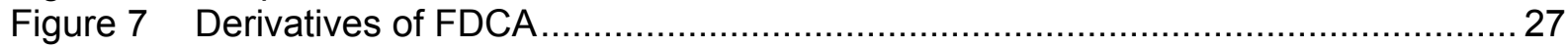

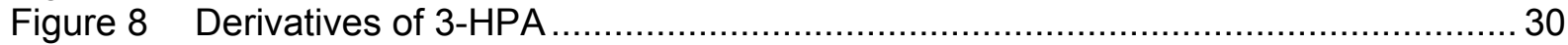

Figure 9 Aspartic Acid Chemistry to Derivatives ........................................................ 33

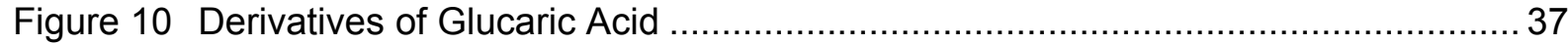

Figure 11 Glutamic Acid and its Derivatives .............................................................. 40

Figure 12 Itaconic Acid Chemistry to Derivatives ...................................................... 43

Figure 13 Derivatives of Levulinic Aid ................................................................... 47

Figure 14 3-HBL Chemistry to Derivatives ............................................................... 51

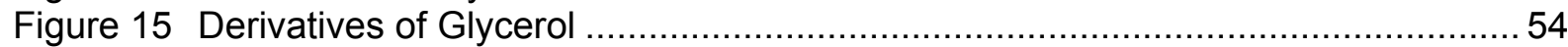

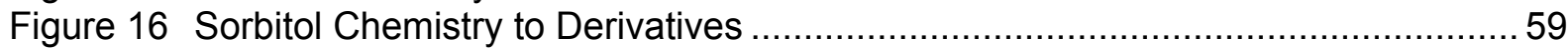

Figure 17 Chemistry to Derivatives of Xylitol and Arabinitol .......................................... 63 


\section{Executive Summary}

This report identifies twelve building block chemicals that can be produced from sugars via biological or chemical conversions. The twelve building blocks can be subsequently converted to a number of high-value bio-based chemicals or materials. Building block chemicals, as considered for this analysis, are molecules with multiple functional groups that possess the potential to be transformed into new families of useful molecules. The twelve sugar-based building blocks are 1,4-diacids (succinic, fumaric and malic), 2,5-furan dicarboxylic acid, 3-hydroxy propionic acid, aspartic acid, glucaric acid, glutamic acid, itaconic acid, levulinic acid, 3-hydroxybutyrolactone, glycerol, sorbitol, and xylitol/arabinitol.

\begin{tabular}{|c|}
\hline Butlding Blocks \\
\hline 1,4 succinic, fumaric and malic acids \\
\hline 2,5 furan dicarboxylic acid \\
\hline 3 hydroxy propionic acid \\
\hline aspartic acid \\
\hline glucaric acid \\
\hline glutamic acid \\
\hline itaconic acid \\
\hline levulinic acid \\
\hline 3-hydroxybutyrolactone \\
\hline glycerol \\
\hline sorbitol \\
\hline xylitol/arabinitol \\
\hline
\end{tabular}

The synthesis for each of the top building blocks and their derivatives was examined as a two-part pathway. The first part is the transformation of sugars to the building blocks. The second part is the conversion of the building blocks to secondary chemicals or families of derivatives. Biological transformations account for the majority of routes from plant feedstocks to building blocks, but chemical transformations predominate in the conversion of building blocks to molecular derivatives and intermediates. The challenges and complexity of these pathways, as they relate to the use of biomass derived sugars and chemicals, were briefly examined in order to highlight R\&D needs that could help improve the economics of producing these building blocks and derivatives. Not surprisingly, many of the transformations and barriers revealed in this analysis are common to the existing biological and chemical processing of sugars.

The final selection of 12 building blocks began with a list of more than 300 candidates. The shorter list of 30 potential candidates was selected using an iterative review process based on the petrochemical model of building blocks, chemical data, known market data, properties, performance of the potential candidates and the prior industry experience of the team at PNNL and NREL. This list of 30 was ultimately reduced to 12 by examining the potential markets for the building blocks and their derivatives and the technical complexity of 
the synthesis pathways. A second-tier group of building blocks was also identified as viable candidates. These include gluconic acid, lactic acid, malonic acid, propionic acid, the triacids, citric and aconitic; xylonic acid, acetoin, furfural, levoglucosan, lysine, serine and threonine. Recommendations for moving forward include examining top value products from biomass components such as aromatics, polysaccharides, and oils; evaluating technical challenges in more detail related to chemical and biological conversions; and increasing the suites of potential pathways to these candidates. 


\section{Background}

America is fortunate to possess abundant and diverse agricultural and forest resources, unused cropland and favorable climates. Together with a remarkable talent to develop new technologies, we have a tremendous opportunity to use domestic, sustainable resources from plants and plant-derived resources to augment our domestic energy supply.

The Biomass Program, in the Energy Efficiency and Renewable Energy Office in the Department of Energy directly supports the goals of The President's National Energy Policy, the Biomass R\&D Act of 2000 and the Farm Security and Rural Investment Act of 2002. To accomplish these goals, the Program supports the integrated biorefinery, a processing facility that extracts carbohydrates, oils, lignin, and other materials from biomass, converts them into multiple products including fuels and high value chemicals and materials. Already today, corn wet and dry mills, and pulp and paper mills are examples of biorefinery facilities that produce some combination of food, feed, power and industrial and consumer products.

This report, the first of several envisioned to examine value-added products from all biomass components, identifies a group of promising sugar-derived chemicals and materials that could serve as an economic driver for a biorefinery. By integrating the production of higher value bioproducts into the biorefinery's fuel and power output, the overall profitability and productivity of all energy related products will be improved. Increased profitability makes it more attractive for new biobased companies to contribute to our domestic fuel and power supply by reinvesting in new biorefineries. Increased productivity and efficiency can also be achieved through operations that lower the overall energy intensity of the biorefinery's unit operations, maximize the use of all feedstock components, byproducts and waste streams, and use economies of scale, common processing operations, materials, and equipment to drive down all production costs. 


\section{Objective}

In 2002, The US DOE Office of Energy Efficiency and Renewable Energy reorganized to combine previously separate biofuels, biopower, and biobased products programs into a single Biomass Program. Promotion of biorefineries producing multiple products, including higher-value chemicals as well as fuels and power, is a main objective of the consolidated program. The Office of the Biomass Program asked research staff at the National Renewable Energy Laboratory (NREL) and Pacific Northwest National Laboratory (PNNL) to identify the top ten opportunities for the production of value-added chemicals from biomass that would economically and technically support the production of fuels and power in an integrated biorefinery and identify the common challenges and barriers of associated production technologies. This report is a companion study to ongoing program planning reports for the Biomass Office including a Multiyear Program Plan, a Multiyear Technical Plan, an Analysis Plan, a Communications Plan, and an Annual Operating Plan. 


\section{Overall Approach}

The separate steps in the overall consideration for this analysis are depicted in the following flow diagram (Figure 1).

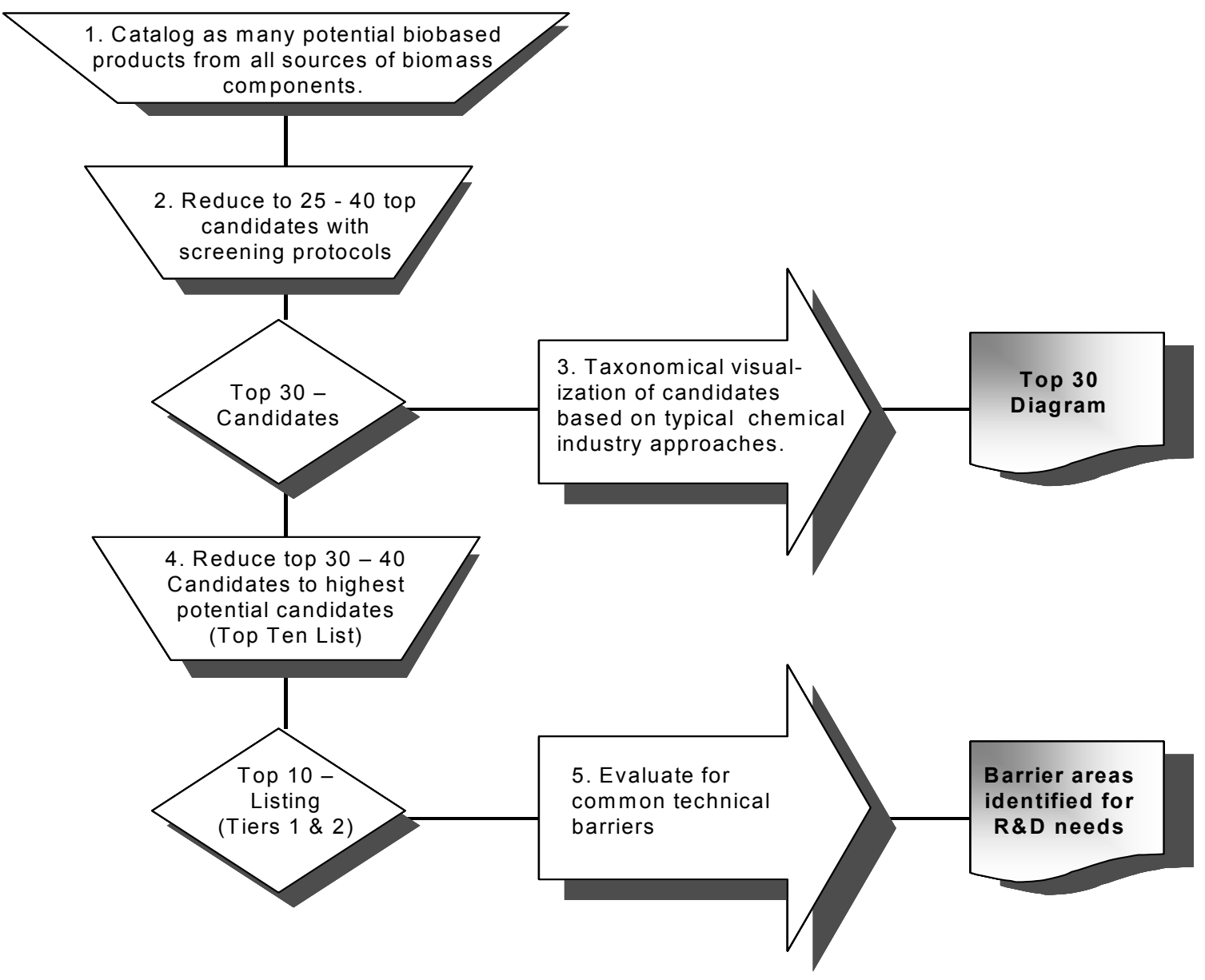

Figure 1 - Visual Representation of Overall Selection Strategy

A group of over 300 possible building block chemicals was assembled from a variety of resources and compiled in an Access database. The source materials included previous DOE and National Laboratory reports and industry and academic studies listed in the Bibliography. The database includes a chemical name, structure, sources for the biomass feedstock, the current and potential production processes, a designation as a commodity, specialty, polymer or food/ag chemical, and pertinent citation information. The initial screening criteria included the cost of feedstock, estimated processing costs, current market volumes and prices, and relevance to current or future biorefinery operations. Interestingly, this first criteria set did not provide sufficient differentiation among the sugar based candidates within the database to produce the smaller number of candidates desired in step 2 of Figure 1. A different approach was needed and developed as described in the next section. 


\section{Initial Screening to the Top 30}

A more effective screening tool was found using the concepts employed in traditional petrochemical industry flow-charts as shown in the representative example in Figure 2 . All of the products from the petrochemical industry are derived from 8-9 foundation chemicals. An iterative review process was established which used chemical and market production data, estimates of the material and performance properties of the potential candidates and over 75 years of cumulative industry experience of the research team as the basis for the down selection. Figure 3 gives a graphical representation of the top 30 building blocks analogous to the example of the petrochemical industry flow chart shown in Figure 2. This figure depicts the value chain approach used in the downselection process.

From the initial list of over 300 , the team systematically down selected to a smaller list using factors that are important components of the strategic criteria shown in Table 1. The screening criteria for this first round included the raw material and estimated processing costs, estimated selling price, the technical complexity associated with the best available processing pathway and the market potential for each of the candidate building blocks.

Table 1 - Biorefinery Strategic Fit Criteria

\begin{tabular}{|c|c|c|c|}
\hline & $\begin{array}{l}\text { Direct Product } \\
\text { Replacement }\end{array}$ & Novel Products & $\begin{array}{l}\text { Buflding Block } \\
\text { Intermediates }\end{array}$ \\
\hline Characteristic & $\begin{array}{l}\text { Competes directly against } \\
\text { existing products and } \\
\text { chemicals derived from } \\
\text { petroleum }\end{array}$ & $\begin{array}{l}\text { Possesses new and improved } \\
\text { properties for replacement of } \\
\text { existing functionality or new } \\
\text { applications }\end{array}$ & $\begin{array}{c}\text { Provide basis of a } \\
\text { diverse portfolio of } \\
\text { products from a single } \\
\text { intermediate }\end{array}$ \\
\hline Examples & $\begin{array}{c}\text { Acrylic acid obtained from } \\
\text { either propylene or lactic } \\
\text { acid }\end{array}$ & $\begin{array}{c}\text { Polylactic acid (glucose via } \\
\text { lactic acid is sole viable } \\
\text { source) }\end{array}$ & $\begin{array}{c}\text { Succinic, levulinic, } \\
\text { glutamic acids, glycerol, } \\
\text { syngas } \\
\end{array}$ \\
\hline Upside & $\begin{array}{l}\text { Markets already exist } \\
\text { Understand cost structures } \\
\text { and growth potential } \\
\text { Substantial reduction in } \\
\text { market risk }\end{array}$ & $\begin{array}{c}\text { Novel products with unique } \\
\text { properties hence cost issues } \\
\text { less important } \\
\text { No competitive petrochemical } \\
\text { routes } \\
\text { Differentiation usually based } \\
\text { on desired performance } \\
\text { New market opportunities } \\
\text { Most effective use of } \\
\text { properties inherent in } \\
\text { biomass }\end{array}$ & $\begin{array}{c}\text { Product swing } \\
\text { strategies can be } \\
\text { employed to reduce } \\
\text { market risks } \\
\text { Market potential is } \\
\text { expanded } \\
\text { Capital investments can } \\
\text { be spread across wider } \\
\text { number of unit } \\
\text { operations } \\
\text { Incorporates } \\
\text { advantages of both } \\
\text { replacement and novel } \\
\text { products }\end{array}$ \\
\hline Downside & $\begin{array}{l}\text { Strictly competing on cost } \\
\text { Competing against } \\
\text { depreciated capital }\end{array}$ & $\begin{array}{l}\text { Market not clearly defined } \\
\text { Capital risk is high } \\
\text { Time to commercialization }\end{array}$ & $\begin{array}{l}\text { Identifying where to } \\
\text { focus R\&D }\end{array}$ \\
\hline
\end{tabular}




\begin{tabular}{|l|l|l|l|}
\hline & $\begin{array}{l}\text { Direct Product } \\
\text { Replacement }\end{array}$ & Novel Products & $\begin{array}{l}\text { Building Block } \\
\text { Intermediates }\end{array}$ \\
\hline \hline & $\begin{array}{c}\text { Limited (green label) } \\
\text { market differentiation" for } \\
\text { biobased vs. } \\
\text { petrochemical based } \\
\text { sources }\end{array}$ & may be long & \\
\hline
\end{tabular}

Almost 50 potential building block candidates resulted from this initial screening.

Continuing to use the strategic fit criteria (direct replacement, novel properties, and potential utility as a building block intermediate) shown in Table 1 above, the team organized the 50 candidates using a carbon number classification framework of one to six carbon compounds (C1 to $\mathrm{C} 6)$.

Next the team reviewed the candidate group for chemical functionality and potential use. Chemical functionality can be based on the number of potential derivatives that can be synthesized in chemical and biological transformations. Simply, a candidate with one functional group will have a limited potential for derivatives where candidate molecules with multiple functional groups will have a much larger potential for derivatives and new families of useful molecules.

Each candidate molecule was then classified for its current utility to serve as a simple intermediate in traditional chemical processing, as a reagent molecule for adding functionality to hydrocarbons, or as byproducts from petrochemical syntheses. Examples of candidates that fell into this category included acetic acid, acetic anhydride, or acetone.

The team then reviewed the candidate group for potential status as a super commodity chemical. Super commodity chemicals are derived from building block chemicals or are coproducts in petrochemical refining. Although the ability of biomass to serve as a source of these compounds is real, the economic hurdles of large capital investments and low market price competitors would be difficult to overcome. Table 2 shows the results of this first screen classified by the carbon number taxonomy C1-C6. 
Table 2 - Top Candidates from the First Screen

\begin{tabular}{|c|c|c|c|c|}
\hline C \# & Name & $\begin{array}{l}\text { Projected or } \\
\text { Known Use } \\
\text { (Building block, } \\
\text { reagent, } \\
\text { intermediate) }\end{array}$ & $\begin{array}{l}\text { Selected } \\
\text { for top } 30\end{array}$ & Rationale \\
\hline 1 & Formic Acid & Reagent & $\mathrm{N}$ & $\begin{array}{l}\text { Very limited BB, use mostly } \\
\text { for adding } C 1\end{array}$ \\
\hline 1 & Methanol & BB- limited & $\mathrm{N}$ & $\begin{array}{c}\text { Super commodity from } \\
\text { syngas }\end{array}$ \\
\hline 1 & $\begin{array}{l}\text { Carbon Monoxide }\left(+\mathrm{H}_{2}\right. \\
\text { gives syngas) }\end{array}$ & BB & $\mathrm{Y}$ & \\
\hline 1 & Carbon dioxide & Reagent & $\mathrm{N}$ & Thermodynamics barrier \\
\hline 2 & Acetaldehyde & Intermediate & $\mathrm{N}$ & V. limited BB. \\
\hline 2 & Acetic acid \& anhydride & $\begin{array}{l}\text { Reagents and } \\
\text { Intermediates }\end{array}$ & $\mathrm{N}$ & $\begin{array}{l}\text { Limited BB, large } \\
\text { commodity scale today } \\
\text { from syngas. Adds C2 }\end{array}$ \\
\hline 2 & Ethanol & Fuel & $\mathrm{N}$ & $\begin{array}{l}\text { Major use envisioned as } \\
\text { fuel. Limited BB. Will } \\
\text { become supercommodity }\end{array}$ \\
\hline 2 & Glycine & Reagent & $\mathrm{N}$ & $\begin{array}{c}\text { V. limited BB. Few uses } \\
\text { envisioned }\end{array}$ \\
\hline 2 & Oxalic acid & Reagent & $\mathrm{N}$ & $\begin{array}{l}\text { Used primarily as chelator } \\
\text { and reagent }\end{array}$ \\
\hline 2 & Ethylene glycol & BB \& Product & $\mathrm{N}$ & Super commodity \\
\hline 2 & Ethylene oxide & BB \& Reagent & $\mathrm{N}$ & Super commodity \\
\hline 3 & Alanine & Intermediate & $\mathrm{N}$ & $\begin{array}{c}\text { V. limited BB. Few uses } \\
\text { envisioned }\end{array}$ \\
\hline 3 & Glycerol & $\mathrm{BB}$ & $\mathrm{Y}$ & \\
\hline 3 & 3-Hydroxypropionic acid & $\mathrm{BB}$ & $\mathrm{Y}$ & \\
\hline 3 & Lactic acid & $\mathrm{BB}$ & $\mathrm{Y}$ & \\
\hline 3 & Malonic acid & BB \& reagent & $\mathrm{Y}$ & \\
\hline 3 & Serine & BB & $Y$ & \\
\hline 3 & Propionic acid & BB \& reagent & $\mathrm{Y}$ & \\
\hline 3 & Acetone & Intermediate & $\mathrm{N}$ & $\begin{array}{l}\text { Super commodity, by- } \\
\text { product from cumene to } \\
\text { phenol synthesis }\end{array}$ \\
\hline 4 & Acetoin & BB & $Y$ & \\
\hline 4 & Aspartic acid & $\mathrm{BB}$ & $Y$ & \\
\hline 4 & Butanol & Intermediate & $\mathrm{N}$ & $\begin{array}{c}\text { Large commodity chemical, } \\
\text { Not a good BB, but large } \\
\text { intermediates market. No } \\
\text { competitive advantage from } \\
\text { biomass }\end{array}$ \\
\hline 4 & Fumaric acid & BB & $Y$ & \\
\hline
\end{tabular}




\begin{tabular}{|c|c|c|c|c|}
\hline C \# & Name & $\begin{array}{l}\text { Projected or } \\
\text { Known Use } \\
\text { (Building block, } \\
\text { reagent, } \\
\text { intermediate) }\end{array}$ & $\begin{array}{l}\text { Selected } \\
\text { for top } 30\end{array}$ & Rationale \\
\hline 4 & 3-Hydroxybutryolactone & BB & $\mathrm{Y}$ & \\
\hline 4 & Malic acid & $\mathrm{BB}$ & $\mathrm{Y}$ & \\
\hline 4 & Succinic acid & BB & $\mathrm{Y}$ & \\
\hline 4 & Threonine & BB & $\mathrm{Y}$ & \\
\hline 5 & Arabinitol & $\mathrm{BB}$ & $\mathrm{Y}$ & \\
\hline 5 & Furfural & $\mathrm{BB}$ & $\mathrm{Y}$ & \\
\hline 5 & Glutamic acid & BB & $\mathrm{Y}$ & \\
\hline 5 & Glutaric acid & $\mathrm{BB}$ & $\mathrm{N}$ & $\begin{array}{l}\text { V. limited market. } \\
\text { Indeterminate set of } \\
\text { derivatives }\end{array}$ \\
\hline 5 & Itaconic acid & $\mathrm{BB}$ & $\mathrm{Y}$ & \\
\hline 5 & Levulinic acid & $\mathrm{BB}$ & $Y$ & \\
\hline 5 & Proline & $\mathrm{BB}$ & $\mathrm{N}$ & $\begin{array}{c}\text { Limited market. } \\
\text { Indeterminate set of } \\
\text { derivatives }\end{array}$ \\
\hline 5 & Xylitol & $\mathrm{BB}$ & $\mathrm{Y}$ & \\
\hline 5 & Xylonic acid & $\mathrm{BB}$ & $Y$ & \\
\hline 6 & Aconitic acid & $\mathrm{BB}$ & $Y$ & \\
\hline 6 & Adipic acid & Intermediate & $\mathrm{N}$ & $\begin{array}{c}\text { Super commodity. } \\
\text { Examined previously by } \\
\text { DOE/industry with little } \\
\text { success }\end{array}$ \\
\hline 6 & Ascorbic acid & BB & $\mathrm{N}$ & $\begin{array}{c}\text { Limited market. } \\
\text { Indeterminate set of } \\
\text { derivatives. Subject of } \\
\text { successful NIST ATP work }\end{array}$ \\
\hline 6 & Citric acid & $\mathrm{BB}$ & $\mathrm{Y}$ & \\
\hline 6 & Fructose & BB & $\mathrm{N}$ & $\begin{array}{c}\text { Other routes to the } \\
\text { derivatives would be easier } \\
\text { than from fructose }\end{array}$ \\
\hline 6 & $\begin{array}{c}\text { 2,5 Furan dicarboxylic } \\
\text { acid }\end{array}$ & BB & $\mathrm{Y}$ & \\
\hline 6 & Glucaric acid & $\mathrm{BB}$ & $Y$ & \\
\hline 6 & Gluconic acid & $\mathrm{BB}$ & $Y$ & \\
\hline 6 & Kojic \& Comeric acid & $\mathrm{BB}$ & $\mathrm{N}$ & $\begin{array}{l}\text { V. limited market. } \\
\text { Indeterminate set of } \\
\text { derivatives }\end{array}$ \\
\hline 6 & Lysine & $\mathrm{BB}$ & $\mathrm{Y}$ & \\
\hline 6 & Sorbitol & BB & $Y$ & \\
\hline
\end{tabular}




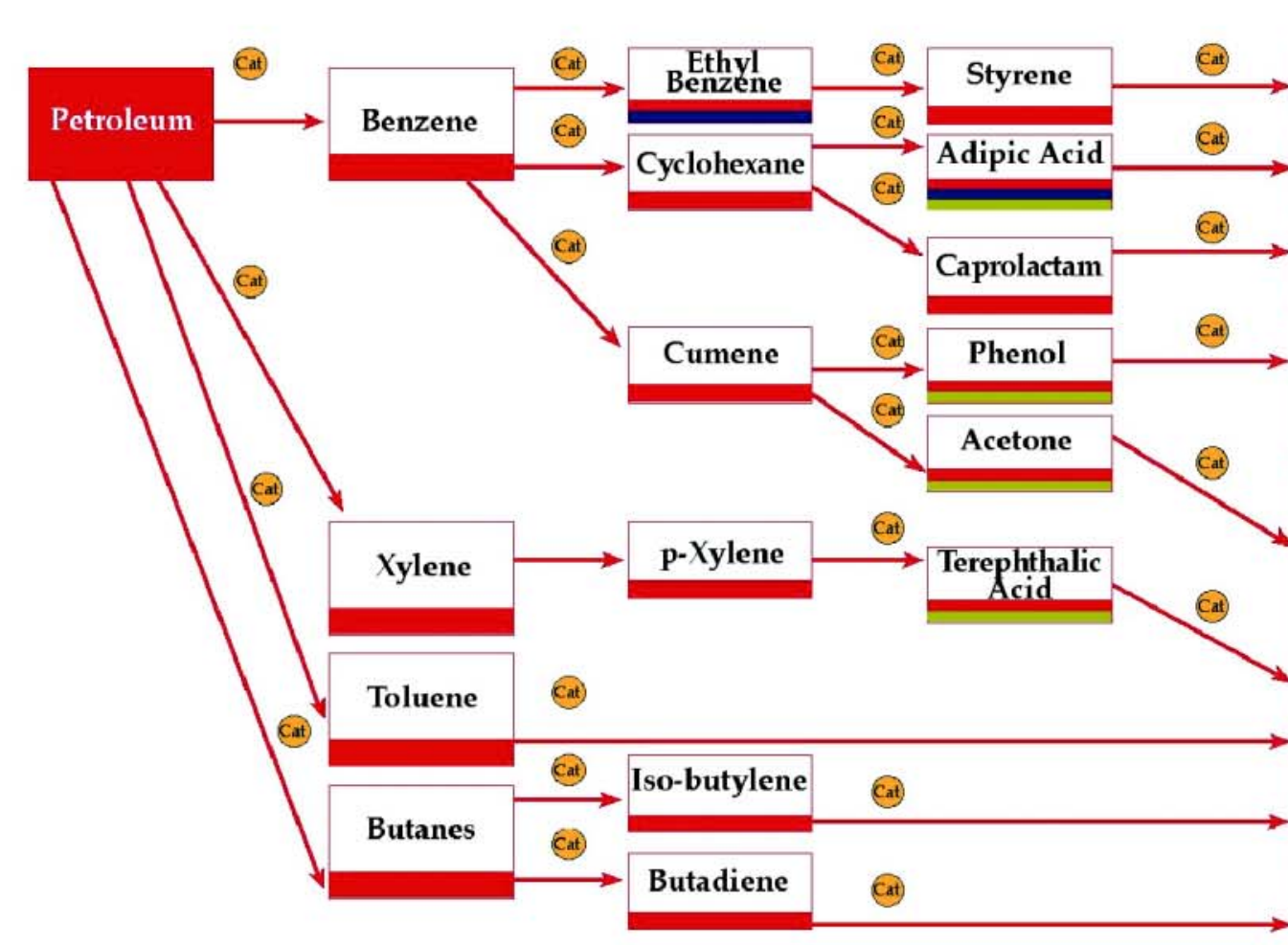

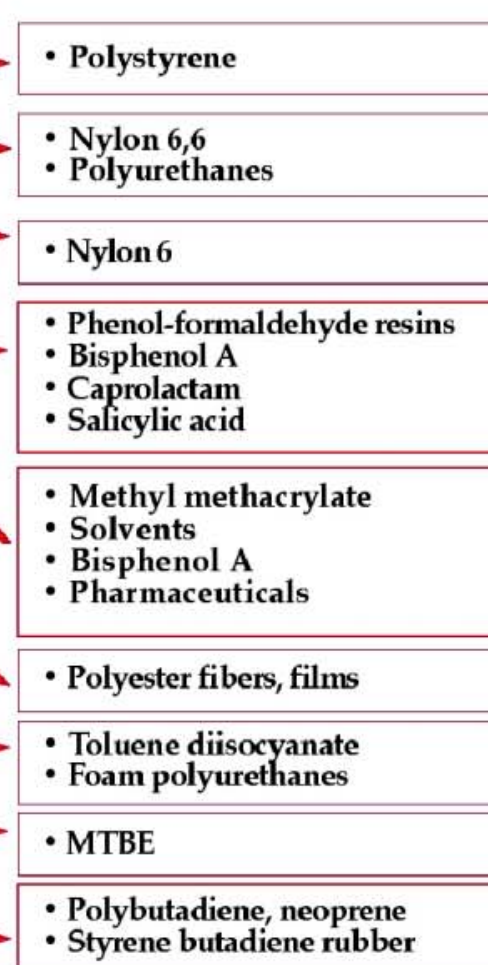
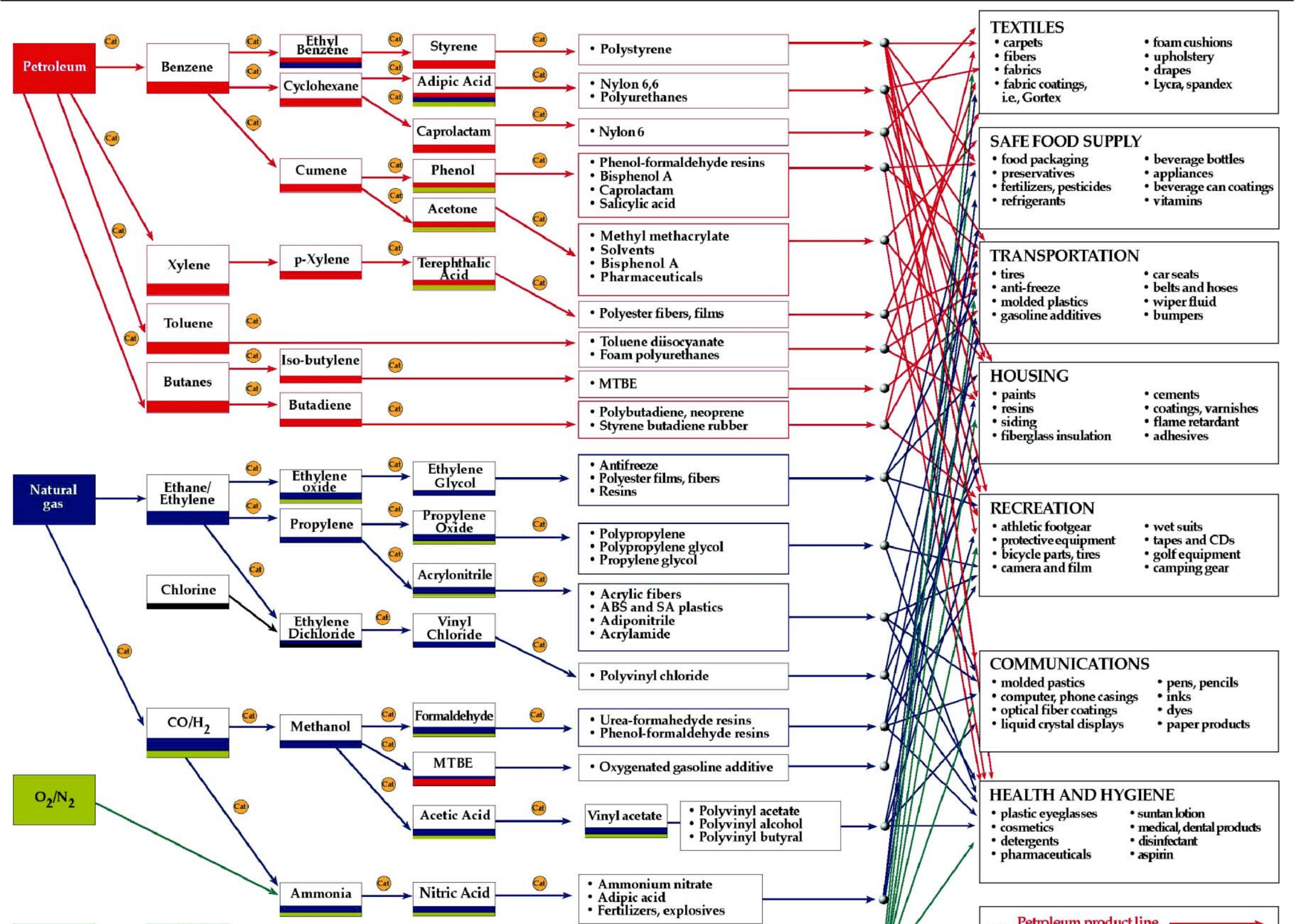

\section{: Antifreeze}

: Polypropylene
Polypropylene glyco - Propylene glycol

: Acrylic fibers - Adiponitrile - Acrylamide

- Polyvinyl chloride
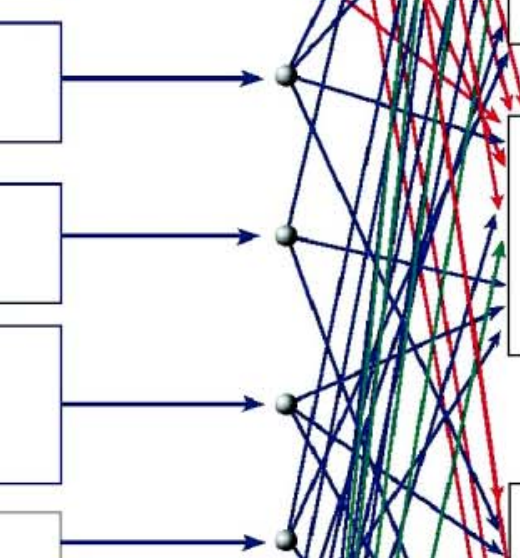

- fiberglass insulation $\cdot$ adh

\section{RECREATION}

$\begin{array}{ll}: \text { athletic footgear } & :_{\text {pret suits }} \\ \text { protective equipment } & \text { tapes and } \mathrm{CDs}\end{array}$

: bicycle parts, tires $\quad$ : golf equipmen

- Urea-formahedyde resins - Phenol-formaldehyde resins - Oxygenated gasoline additive

Vinyl acetate - : Polyvinyl acetate

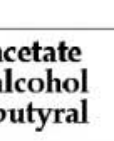

: Ammonium nitrate - Fertilizers, explosives

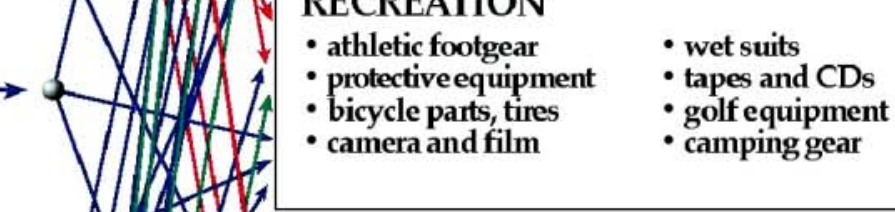

COMMUNICATIONS

- molded pastics $\quad \cdot$ pens, pencils

:computer, phonecasings $\begin{aligned} & \text { : pens } \\ & \text { : inks } \\ & \text { optical }\end{aligned}$

$\begin{array}{ll}\text { optical fiber coatings } & \text { : dyes } \\ \text { - liqustal displays products } & \end{array}$

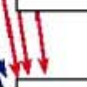

HEALTH AND HYGIENE

$\begin{array}{ll}\text { - plastic eyeglasses } & \text { - suntan lotion } \\ \text { cosmetics } & \text {-medical, dental products }\end{array}$ - detergents $\quad$ pharmaceuticals ${ }_{\text {aspinin }}$

Petroleum product line

E SO ${ }_{2}$ productline

Catalytic Process

Figure 2 - An Example of a Flow-Chart for Products from Petroleum-based Feedstocks 


\section{Biomass \\ Feedstocks \\ Intermediate Platforms \\ Building Blocks \\ Secondary Chemicals}

\section{Products/Uses}

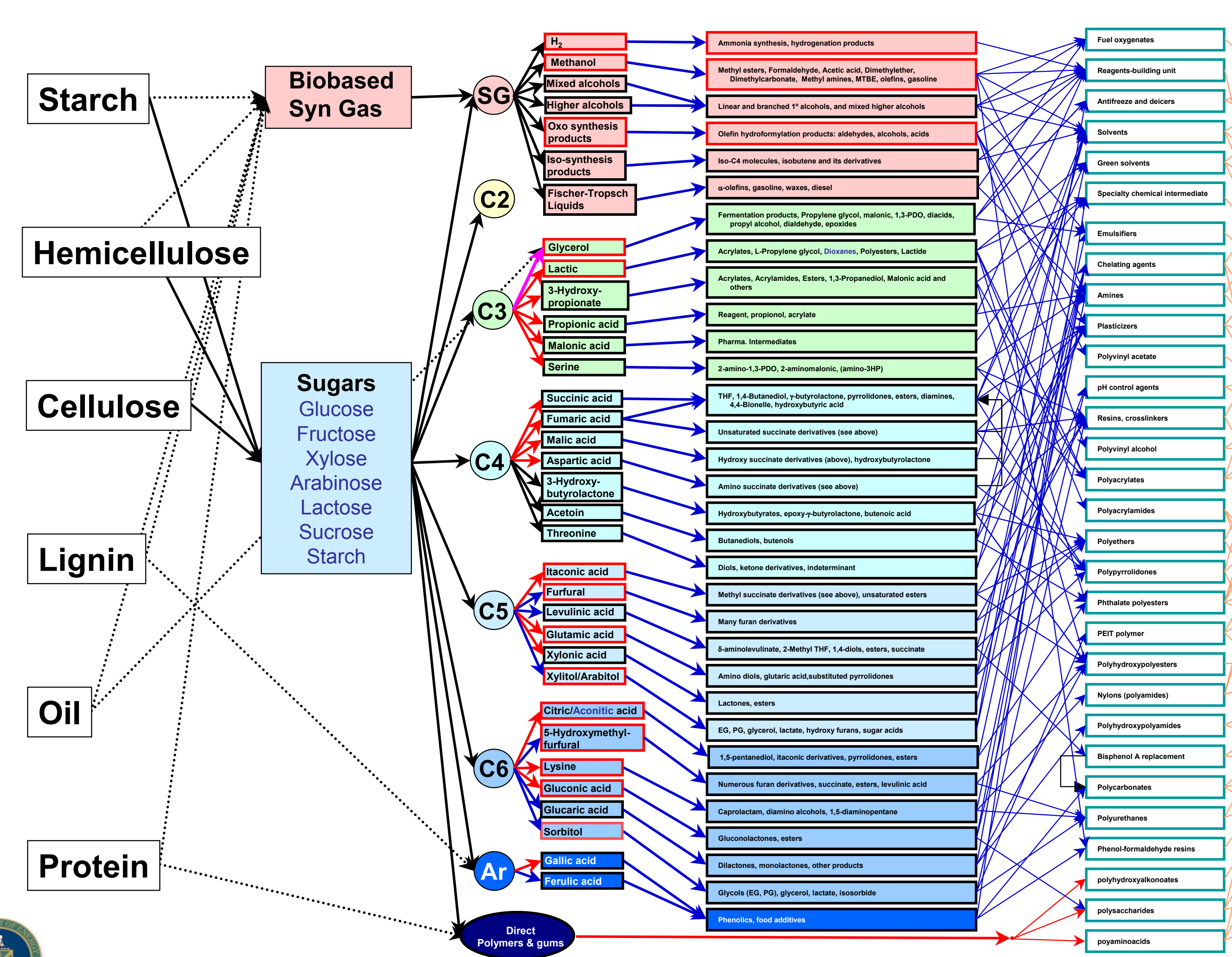

Industrial

Corrosion inhibitors, dust control boiler water treatment, gas

purification, emission abatement, specialty lubricants, hoses, seals

\section{Transportation}

Fuels, oxygenates, anti-freeze, wiper fluids molded plastics, car seats, belts hoses, bumpers, corrosion inhibitors

Textiles

Carpets, Fibers, fabrics, fabric

coatings, foam cushions, upholstery, drapes, lycra, spandex

Safe Food Supply

Food packaging, preservatives,

fertilizers, pesticides, beverage

bottles, appliances, beverage can

coatings, vitamins

Environment

Water chemicals, flocculants,

chelators, cleaners and detergents

\section{Communication}

Molded plastics, computer casings, optical fiber coatings, liquid crysta displays, pens, pencils, inks, dyes, paper products

Housing

Paints, resins, siding, insulation, cements, coatings, varnishes, flame retardents, adhesives, carpeting

\section{Recreation}

Footgear, protective equipment, camera and film, bicycle parts \& tires,

wet suits, tapes-CD's-DVD's, golf

equipment, camping gear, boats

\section{Health and Hygiene}

Plastic eyeglasses, cosmetics,

detergents, pharmaceuticals, suntan

lotion, medical-dental products

disinfectants, aspirin

Figure 3 - Analogous Model of a Biobased Product Flow-chart for Biomass Feedstocks 
By eliminating those that did not meet the criteria, a list of top 30 building block candidates was produced that 1) exhibited multiple functionalities suitable for further conversion as derivatives or molecular families, 2) could be produced from both lignocellulosics and starch, 3) were C1-C6 monomers, 4) were not aromatics derived from lignin, and 5) were not already supercommodity chemicals. These are shown in Table 3.

Table 3 - Down Selection - Top 30 Results

\begin{tabular}{|c|c|}
\hline $\begin{array}{l}\text { Carbon } \\
\text { Number }\end{array}$ & Potential Top 30 candidates \\
\hline 1 & Carbon monoxide \& hydrogen (syngas) \\
\hline 2 & None \\
\hline 3 & $\begin{array}{c}\text { Glycerol, } 3 \text { hydroxypropionic acid, lactic acid, malonic acid, propionic acid, } \\
\text { serine }\end{array}$ \\
\hline 4 & $\begin{array}{l}\text { Acetoin, aspartic acid, fumaric acid, 3-hydroxybutyrolactone, malic acid, } \\
\text { succinic acid, threonine }\end{array}$ \\
\hline 5 & $\begin{array}{l}\text { Arabinitol, furfural, glutamic acid, itaconic acid, levulinic acid, proline, } \\
\text { xylitol, xylonic acid }\end{array}$ \\
\hline 6 & $\begin{array}{c}\text { Aconitic acid, citric acid, } 2,5 \text { furan dicarboxylic acid, glucaric acid, lysine, } \\
\text { levoglucosan, sorbitol }\end{array}$ \\
\hline
\end{tabular}

Of note, C2 compounds such as acetic acid and acetic anhydride, were considered to have lower potential and C3 compounds such as acetone which is already a petrochemical byproduct were not included.

In addition, commercial scale conversion of syngas to hydrogen, ammonia, methanol, alcohols and aldehydes, (oxosyntheses), and Fischer-Tropsch products already exist. 


\section{Selected Sugar-derived Chemicals}

The second round of down selection from the top 30 building block candidates identified twelve sugar derived building blocks shown in Table 4.

Table 4 - The Top Sugar-derived Building Blocks

\begin{tabular}{|c|}
\hline Building Blocks \\
\hline 1,4 diacids (succinic, fumaric and malic) \\
\hline 2,5 furan dicarboxylic acid \\
\hline 3 hydroxy propionic acid \\
\hline aspartic acid \\
\hline glucaric acid \\
\hline glutamic acid \\
\hline itaconic acid \\
\hline levulinic acid \\
\hline 3-hydroxybutyrolactone \\
\hline glycerol \\
\hline sorbitol \\
\hline xylitol/arabinitol \\
\hline
\end{tabular}

In some cases molecules have been grouped together because of the potential synergy related to their structures. These molecules can be 1) isomers, 2) interconverted to afford the same molecule, and/or 3) the derivatives pathway leading to essentially the same family of products. These candidate groups are xylitol/arbinitol and the 1,4-dicarboxylic acids, succinic, malic and fumaric acid.

Summary information about each building block is presented in two different formats. First, a table, or "bio" of qualitative properties was compiled characterizing each building block and derivative. For example, Table 5 shows the bio for the 3-HPA building block. Tables 6 and 7 show families of 3-HPA transformations that in these cases involve reduction and dehydration to the corresponding derivatives. The remaining building block and derivative pathway bios and further discussion appear in Section 9. 
Table 5 - Sugar Transformation to 3-HPA

\begin{tabular}{|c|c|c|}
\hline $\begin{array}{l}\text { Buflding Block } \\
\text { Pathway }\end{array}$ & Technical Barriers & $\begin{array}{l}\text { Direct Uses of } \\
\text { Bullding Block }\end{array}$ \\
\hline \multicolumn{3}{|l|}{$\begin{array}{l}\text { Chemical - Unknown } \\
\text { or multistep, costly } \\
\text { process }\end{array}$} \\
\hline $\begin{array}{l}\text { Biotransformation- } \\
\text { Fermentation }\end{array}$ & $\begin{array}{c}\text { Being done by industry. Fermentation } \\
\text { pathway not known } \\
\text { General needs in fermentation } \\
\text { Improving microbial biocatalyst to 1) reduce } \\
\text { other acid coproducts, 2) increase yields and } \\
\text { productivities } \\
\text { Lower costs of recovery process to reduce } \\
\text { unwanted salts } \\
\text { Scale-up and system integration issues }\end{array}$ & None \\
\hline
\end{tabular}

Table 6 - Reductive Transformation - 3HP to 1,3 PDO via catalytic dehydrogenation

\begin{tabular}{|c|c|c|}
\hline $\begin{array}{c}\text { Derivative or } \\
\text { Derivative Family }\end{array}$ & Technical barriers & $\begin{array}{l}\text { Potential use of } \\
\text { derivatives }\end{array}$ \\
\hline 1, 3-propanediol & $\begin{array}{c}\text { Direct reduction of carboxylic acid with high } \\
\text { selectivity } \\
\text { Reduction at mild conditions - moderate } \\
\text { hydrogen pressure, low T } \\
\text { Tolerance to inhibitory elements or } \\
\text { material) } \\
\text { components of biomass based feedstocks } \\
\text { Robust catalysts and catalyst lifetimes }\end{array}$ & $\begin{array}{c}\text { Sorona fiber } \\
\text { mater }\end{array}$ \\
\hline
\end{tabular}

Table 7 - Dehydrative Transformation - 3-HPA to acrylic acid via catalytic dehydration

\begin{tabular}{|c|c|c|}
\hline $\begin{array}{c}\text { Derivative or } \\
\text { Derivative family }\end{array}$ & Technical barriers & $\begin{array}{l}\text { Potential use of } \\
\text { derivatives }\end{array}$ \\
\hline Acrylate family & $\begin{array}{c}\text { Selective dehydration without side reactions } \\
\text { (high value need for biomass) } \\
\text { New heterogeneous catalysts (i.e. solid acid } \\
\text { catalysts) to replace liquid catalysts and to } \\
\text { improve existing catalyst based systems }\end{array}$ & $\begin{array}{c}\text { Contact lenses, } \\
\text { diapers (Super } \\
\text { Absorbent Polymers } \\
\text { SAPs) }\end{array}$ \\
\hline
\end{tabular}


In addition to each bio summary a visual representation, or "star" diagram, was created for each building block. These diagrams use the star's projections to represent the different pathways for converting building blocks to derivatives or secondary chemicals. The number and nature of each derivative pathway represents each building block's potential value as a starting material for a variety of end uses. Unlike the building blocks, the derivatives can be categorized into two types. One type of derivative could be used as current replacements for industrial petrochemicals or biochemicals. The second type of derivative could serve as novel material with new performance characteristics that would allow new applications or create a new market segment.

Each transformation pathway was assessed for 4 characteristics including 1) current industrial use, 2) a transformation analogous to a currently known technology, 3) moderate process development requirement and 4) significant process development requirement.

The 3-hydroxypropionic acid star diagram is shown below in 2. The building block star diagrams for all the top 12 appear in Section 9. Derivatives are grouped by families as a function of chemical transformations.

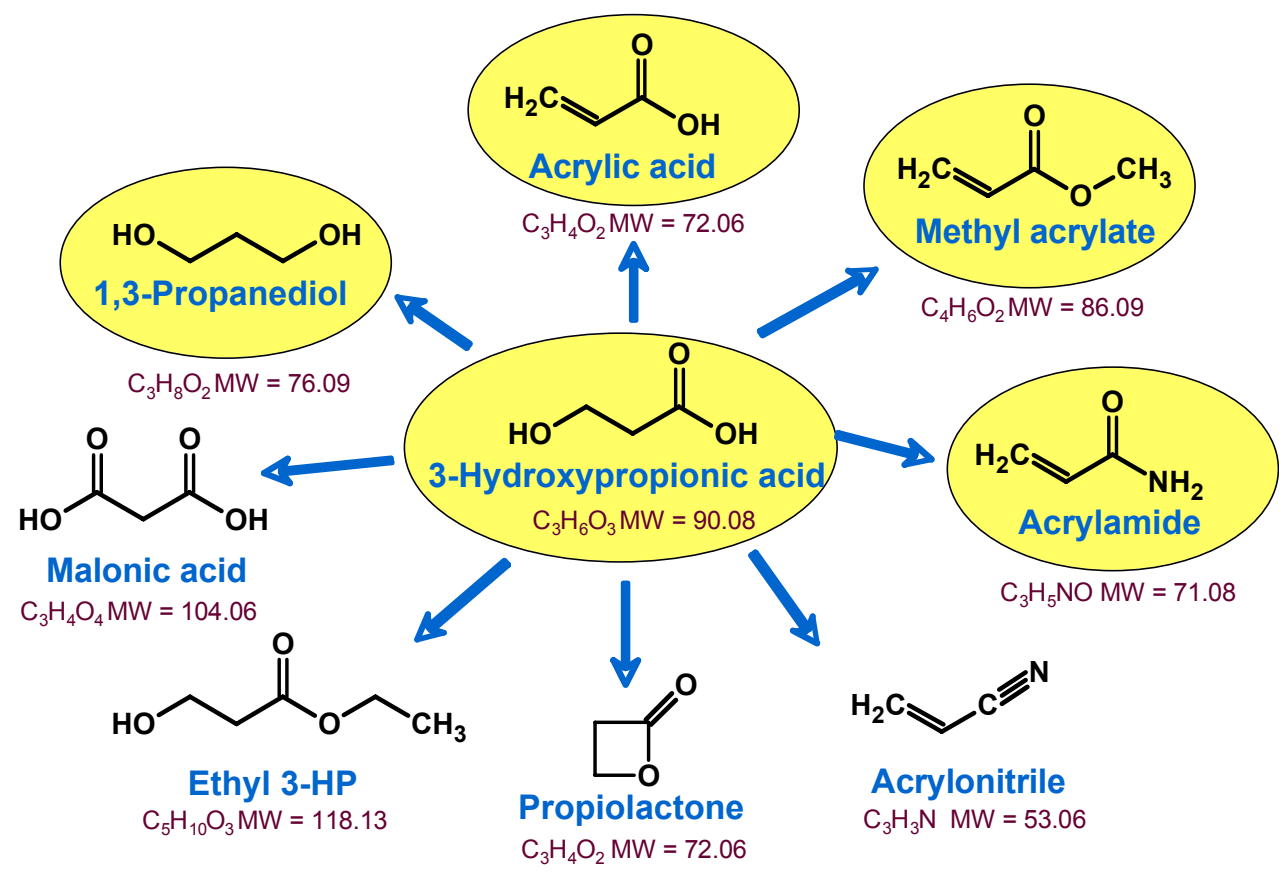

Figure 4 - Star Diagram of 3-Hydroxypropionic Acid

The circled derivatives are those in commercial use and produced in commodity-scale volume today. A dashed line indicates a lack of knowledge about how to undertake the proposed pathway. The team attempted to identify most of the derivative pathways that could be replacements for petrochemically-derived compounds and for novel compounds that have growth potential. Taken together the number of potential pathways and associated technical barriers for each star are an indication of the value of the candidate as a building block. 
As part of the screening criteria the team used standard reference documents (listed in the Bibliography) and industrial chemistry experience to identify the potential transformation pathways. Four criteria were used to rank the potential building block candidates: 1) strategic fit for lignocellulosic and starch biomass within the biorefinery, 2) value of the building block and its derivatives as a replacement or novel chemical, 3) the technical complexity of each part of the pathway transformation (sugars to building blocks and building blocks to derivatives), and 4) the building block's potential to produce families or groups of similar derivatives. Each building block candidate was given a consensus score. From a statistical analysis 12 candidates ranked above average, three were at the mean (lactic, levoglucosan and lysine) with the remaining falling below the average. Tier one building blocks or those whose score was above average are listed in Table 4 above. Tier two candidates, gluconic acid, lactic acid, malonic acid, propionic acid, the triacids (citric and aconitic) xylonic acid, acetoin, furfural, levoglucosan, lysine, serine and threonine were judged to have somewhat lower potential. 


\section{Syngas Results - Top Products}

For the purposes of this study hydrogen and methanol comprise the best near-term prospects for biobased commodity chemical production because obtaining simple alcohols, aldehydes, mixed alcohols and Fischer-Tropsch liquids from biomass are not economically viable and require additional development Therefore no further down select from syngasderived products was undertaken. This determination was based on a review of the literature and a progress review of the OBP Thermochemical Platform R\&D at NREL in August 2003. The review identified gas cleanliness as a key barrier to economic production of syngas from biomass. A comprehensive report including economic analysis, technical challenges and energy impacts of syngas to liquid processes is available. ${ }^{1}$

1P. Spath and D. Dayton_Preliminary Screening - Technical and Economic Assessment of Synthesis Gas to Fuels and Chemicals with Emphasis on the Potential for Biomass-derived Syngas, NREL Technical Report NREL/TP-510-34929, December 2003) 


\section{Pathways and Challenges}

Before common technical barriers can be listed and described, the team identified the most viable biological and chemical transformation pathways from sugars to building blocks. A large number of sugar to building block transformations can be done by aerobic fermentation employing fungi, yeast or bacteria. Chemical and enzymatic transformations are also important process options. It should be noted however, that pathways with more challenges and barriers are less likely be considered as viable industrial processes. Currently known sugars to building blocks that are commercially available are listed in Table 8.

Similarly, the team examined the most common transformations involved in converting building blocks to derivatives. Chemical reduction, oxidation, dehydration, bond cleavage, and direct polymerization predominated. Here enzymatic biotransformations comprised the largest group of biological conversions. Additionally some biological conversions can be accomplished without the need for an intermediate building block. 1,3-propanediol is a case in point where a set of successive biological processes convert sugar directly to an end product.

Each pathway has its own set of advantages and disadvantages. Biological conversions, of course, can be tailored to result in a specific molecular structure but the operating conditions must be relatively mild. Chemical transformations can operate at high throughput but less conversion specificity is achieved.

Prioritizing the technical barrier categories for chemicals is less clear. For example, biomass is already highly oxidized (contains significant fractions of oxygen) so the numbers of transformations requiring oxidation are relatively low. On the other hand those requiring hydrogenation and dehydration (adding hydrogen or removing oxygen) were much higher. This belies the fact that oxidation is still a difficult thing to do and possesses significant benefits not only for sugars but also oils, lignin, and other biomass components. 
Table 8 - Pathways to Building Blocks from Sugars

\begin{tabular}{|c|c|c|c|c|c|c|}
\hline \multicolumn{7}{|c|}{ Identification of Actual and Potential Pathways to Building Blocks from Sugars } \\
\hline Building Blocks & $\begin{array}{c}\text { Yeast or } \\
\text { Fungal }\end{array}$ & Bacterial & $\begin{array}{c}\text { Yeast or } \\
\text { Fungal }\end{array}$ & Bacterial & $\begin{array}{c}\text { Chemical \& I } \\
\text { Catalytic } \\
\text { Processes I }\end{array}$ & $\begin{array}{l}\text { Biotrans- } \\
\text { formation }\end{array}$ \\
\hline & \multicolumn{2}{|c|}{ AEROBIC FERMENTATIONS } & \multicolumn{2}{|c|}{ ANAEROBIC FERMENTATIONS } & \multicolumn{2}{|c|}{ CHEM-Enzyme TRANSFORMATIONS } \\
\hline 3 Carbon & $\begin{array}{l}\text { Commercial } \\
\text { Product - C }\end{array}$ & $\begin{array}{l}\text { Commercial } \\
\text { Product - C }\end{array}$ & $\begin{array}{l}\text { Commercial } \\
\text { Product - C }\end{array}$ & $\begin{array}{l}\text { Commercial } \\
\text { Product -C }\end{array}$ & $\begin{array}{l}\text { Commercial } \\
\text { Product - C }\end{array}$ & $\begin{array}{l}\text { Commercial } \\
\text { Product - C }\end{array}$ \\
\hline $\begin{array}{l}\text { 3-Hydroxy propionic } \\
\text { acid }\end{array}$ & $\mathbf{X}$ & $\mathbf{X}$ & & & & \\
\hline Glycerol & $-\bar{x}$ & $\underline{X}$ & $-\bar{x}$ & $-\bar{x}$ & C. & \\
\hline Lactic acid & $\mathbf{x}$ & & - & -- & & \\
\hline Malonic acid & $\mathbf{x}$ & & & & $\mathbf{x}$ & \\
\hline Propionic acid & & & & $\mathbf{x}$ & & \\
\hline Serine & $x$ & c. & & & & C \\
\hline \multicolumn{7}{|l|}{ 4 Carbon } \\
\hline $\begin{array}{l}\text { 3-Hydroxy } \\
\text { butyrolactone }\end{array}$ & & & & & $\mathbf{x}$ & \\
\hline Acetoin & $\mathbf{x}$ & $-\bar{x}$ & & X & & \\
\hline Aspartic Acid & $\bar{x}$ & $\bar{x}$ & & & & $\mathbf{x}$ \\
\hline Fumaric Acid & $\mathrm{x}$ & 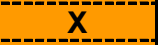 & & & $\mathbf{x}$ & \\
\hline Malic acid & $x$ & $x$ & & & & \\
\hline Succinic acid & $x$ & $-\bar{x}$ & & $\mathrm{X}$ & & $\mathbf{x}$ \\
\hline Threonine & $\mathrm{x}$ & $\mathrm{C}$ & & & & \\
\hline \multicolumn{7}{|l|}{5 Carbon } \\
\hline Arabitol & $x$ & & $x$ & & C & $\mathbf{x}$ \\
\hline Furfural & & & & & C & \\
\hline Glutamic & $x$ & C & & & & \\
\hline Itaconic Acid & C & & & & & \\
\hline Levulinic acid & & & & & $\mathbf{x}$ & \\
\hline Xylitol & $\mathrm{x}$ & & $\mathrm{x}$ & $\mathbf{x}$ & & C \\
\hline \multicolumn{7}{|l|}{\begin{tabular}{|c|}
6 Carbon \\
\end{tabular}} \\
\hline $\begin{array}{l}\text { 2,5 Furan } \\
\text { dicarboxylic acid }\end{array}$ & & & & & $x$ & \\
\hline Aconitic acid & $x$ & & & & & \\
\hline Citric acid & c & & & & & \\
\hline Glucaric acid & $\mathbf{x}$ & X & & & $\mathbf{x}$ & \\
\hline Gluconic acid & C. & $x$ & & & & $\underline{x}$ \\
\hline Levoglucosan & & & & & $\mathbf{x}$ & \\
\hline Lysine & $\mathbf{x}$ & C & & & & \\
\hline Sorbitol & $\mathrm{x}$ & $\mathrm{x}$ & & & $\mathrm{c}$ & $\mathrm{x}$ \\
\hline $\begin{array}{l}\text { Number in each } \\
\text { Pathway category* }\end{array}$ & 21 & 14 & 4 & 6 & 11 & 7 \\
\hline $\begin{array}{l}\text { Commercial } \\
\text { processes }\end{array}$ & 3 & 4 & 0 & 1 & 4 & 2 \\
\hline
\end{tabular}




\section{Moving Forward}

In reality, the first screen choices should not be viewed as an elimination but as generic guidance using criteria that allowed the selection of a top twelve list. Clearly, the sugar focus of this analysis limited the number of opportunities for value-added chemicals beyond C6 compounds. For example, aromatics comprise a very large commodity market for polymers and surfactants. Polysaccharides are a growing market segment because of their potentially valuable properties in various applications such as enhanced oil recovery and paper/metal finishing. Oils, although produced in an established industry, have a broad range of opportunities for diverse market applications. Lignin can afford the entire family of aromatic compounds that are difficult to produce via sugars or oils. It would be worthwhile to assess the potential value of products derived from both oils and lignin as has been done here for sugars and syngas.

We also know that new knowledge and better technologies are needed in dealing with chemical transformations that involve milder oxidations, selective reductions and dehydrations, better control of bond cleavage, and improvements to direct polymerization of multifunctional monomers. For biological transformations, we need better pathway engineering of industrial hosts, better understanding of metabolic pathways and cell biology, lower downstream recovery costs, increased utility of mixed sugar streams, improved molecular thermal stability; and better understanding of enzyme functionality. While it is possible to prepare a very large number of molecular structures from the top building blocks, we have almost no publicly available information about these molecules' behavior, material performance or industrial processing properties. Hence, a comprehensive database on biopolymer performance characteristics would prove extremely useful to both the public and private sector.

It is highly likely we will need to expand the suites of potential pathways and increase our understanding of all the technical barriers beyond the ones summarized here. This knowledge would also lead to a better definition of which biobased feedstock materials hold the most promise as economic drivers for an integrated biorefinery. 
9 Top 12 Candidate Summary Bios 


\subsection{Four Carbon 1,4-Diacids (Succinic, Fumaric, and Malic)}

\subsubsection{Pathways to Building Block From Sugars}

Table 9 - Pathways to Building Block From Sugars [Four Carbon 1,4 Diacids (Succinic, Fumaric, and Malic]

\begin{tabular}{|c|c|c|}
\hline Type of pathway & Technical Barriers & $\begin{array}{c}\text { Direct Uses of } \\
\text { Building Block }\end{array}$ \\
\hline Chemical - None & & \\
\hline $\begin{array}{c}\text { Biotransformation - } \\
\text { Fermentation to } \\
\text { overproduce C4 } \\
\text { diacids from Krebs } \\
\text { cycle pathways }\end{array}$ & $\begin{array}{c}\text { Improving microbial biocatalyst to 1) reduce acetic } \\
\text { acid coproducts, 2) increase yields and } \\
\text { productivities }\end{array}$ & $\begin{array}{c}\text { Lower costs of recovery process to reduce } \\
\text { unwanted salts }\end{array}$ \\
Scale-up and system integration issues
\end{tabular}

9.1.2 Primary Transformation Pathway(s) to Derivatives

Table 10 - Family 1: Reductions [Primary Transformation Pathway(s) to Derivatives Four Carbon 1,4-Diacids (Succinic, Fumaric, and Malic)]

\begin{tabular}{|c|c|c|}
\hline $\begin{array}{c}\text { Derivative or } \\
\text { Derivative Family }\end{array}$ & Technical barriers & $\begin{array}{l}\text { Potential use of } \\
\text { derivatives }\end{array}$ \\
\hline $\begin{array}{c}\text { THF, BDO, GBL } \\
\text { Family }\end{array}$ & $\begin{array}{c}\text { Selective reductions: controlling reduction of } \\
\text { acids to alcohols, lactones and furans } \\
\text { Operation at mild conditions (pressure, T, etc.) } \\
\text { Catalyst tolerance to inhibitory compounds and } \\
\text { catalyst lifetime }\end{array}$ & $\begin{array}{c}\text { Solvents, fibers such } \\
\text { as lycra }\end{array}$ \\
\hline
\end{tabular}

Table 11 - Family 2: Reductive Aminations [Primary Transformation Pathway(s) to Derivatives - Four Carbon 1,4-Diacids (Succinic, Fumaric, and Malic)]

\begin{tabular}{|c|c|c|}
\hline $\begin{array}{l}\text { Derivative or } \\
\text { Derivative Family }\end{array}$ & Technical barriers & $\begin{array}{l}\text { Potential use of } \\
\text { derivatives }\end{array}$ \\
\hline Pyrrolidinone Family & $\begin{array}{c}\text { Selective reductions of acid salts } \\
\text { Operation at mild conditions (pressure, T, etc.) } \\
\text { Catalyst tolerance to inhibitory compounds } \\
\text { Catalyst lifetime in continuous processes }\end{array}$ & $\begin{array}{c}\text { Green solvents, } \\
\text { water soluble } \\
\text { polymers (water } \\
\text { treatment) }\end{array}$ \\
\hline
\end{tabular}


Table 12 - Family 3: Direct Polymerization [Primary Transformation Pathway(s) to Derivatives - Four Carbon 1,4-Diacids (Succinic, Fumaric, and Malic]

\begin{tabular}{|c|c|l|}
\hline $\begin{array}{c}\text { Derivative or } \\
\text { Derivative Family }\end{array}$ & Technical barriers & $\begin{array}{l}\text { Potential use of } \\
\text { derivative } \\
\text { product }\end{array}$ \\
\hline $\begin{array}{c}\text { Straight chain } \\
\text { polymers }\end{array}$ & Commercial polymer processes & Fibers (lycra, others) \\
\hline Branched polymers & $\begin{array}{c}\text { Selective esterifications to control branching } \\
\text { Control of molecular weight \& properties }\end{array}$ & TBD \\
\hline
\end{tabular}

Building Block: Four Carbon Diacids (Succinic, Fumaric, and Malic)

Primary Derivatives:

Family 1: Reductions

Family 2: Reductive Aminations

Family 3: Direct Polymerization

\subsubsection{Building Block Considerations}

The family of 4-carbon diacids is best grouped together, since their production arises from very similar biochemical paths. For the purposes of this summary, succinic acid will be used as a prototypical example, but the concepts described herein apply equally well to fumaric and malic acid. Star diagrams for fumaric and malic acid are found elsewhere in this report. Four carbon dicarboxylic acids have the potential to be a key building blocks for deriving both commodity and specialty chemicals. The basic chemistry of succinic acid is similar to that of the petrochemically derived maleic acid/anhydride. Succinic acid is produced biochemically from glucose using an engineered form of the organism $A$. succiniciproducens and most recently via an engineered Eschericia coli strain developed by DOE laboratories and licensed to a small business. The chemistry of succinic acid to the primary families of derivatives is shown in Figure 5.

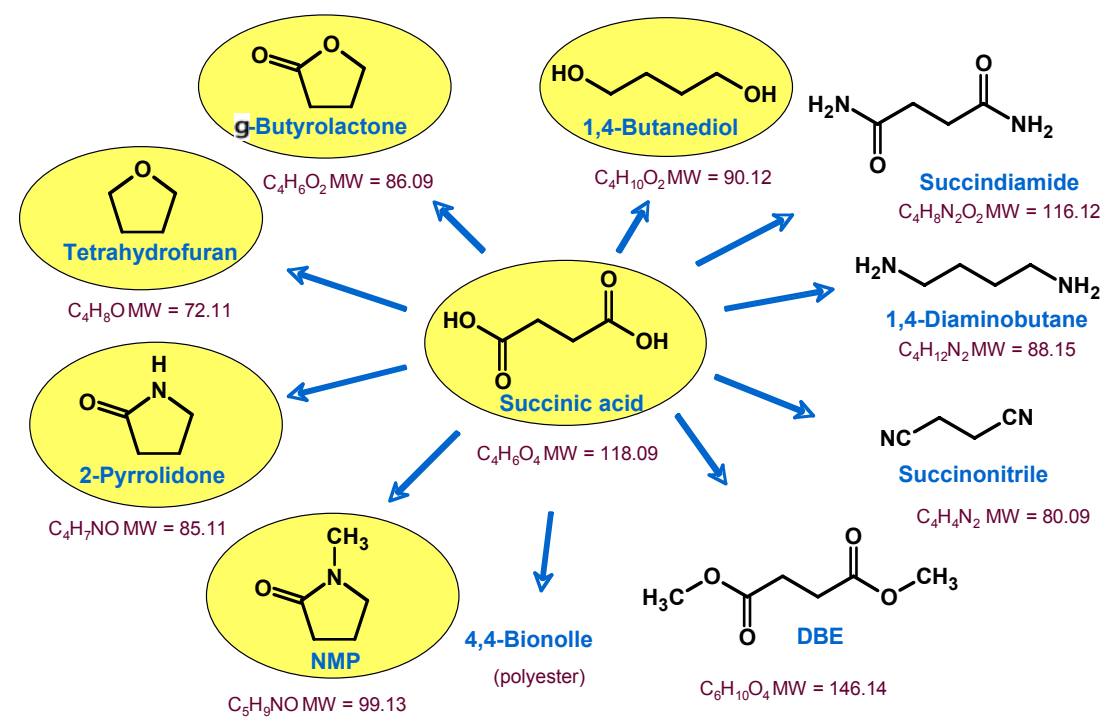

Figure 5 - Succinic Acid Chemistry to Derivatives 
The major technical hurdles for the development of succinic acid as a building block include the development of very low cost fermentation routes. There are currently two organisms under active development for the fermentation of sugars (both C6 and C5) to produce succinic acid. Based on the available information in the literature regarding these two organisms significant improvement in the fermentation is still required to be competitive with petrochemical routes. Figure 6 depicts a simplified PFD of glucose fermentation to succinic acid.

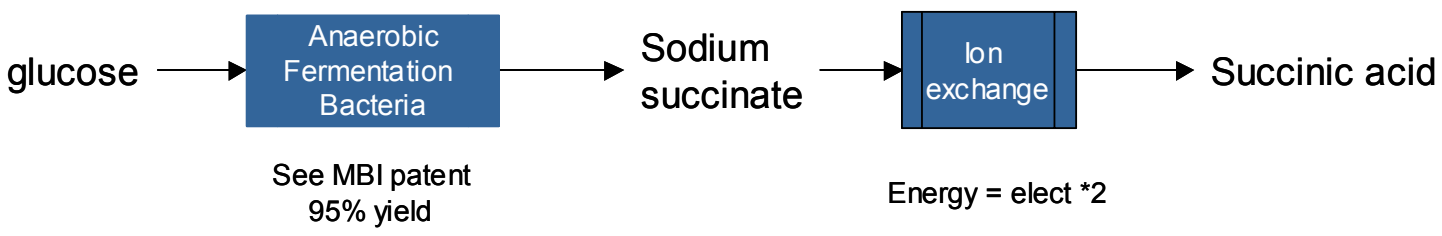

Figure 6 - Simplified PFD of Glucose Fermentation to Succinic Acid

The major elements of improvement in the fermentation include the following:

Productivity: Productivity improvements are required to reduce the capital and operating costs of the fermentation. A minimum productivity of $2.5 \mathrm{~g} / \mathrm{L} / \mathrm{hr}$ needs to be achieved in order for the process to economically competitive.

Nutrient Requirements: It is essential for commercial fermentations to be run using minimal nutrients. Expensive nutrient components such as yeast extract and biotin must be eliminated. The nutrient requirements should be limited to the use of corn steep liquor or equivalent.

Final Titer: Final titer is also important when considering overall process costs. This is not a showstopper but a high final titer will reduce overall separation and concentrating costs.

pH Considerations: In an ideal situation the fermentation would be run at low $\mathrm{pH}$, most preferably without requiring any neutralization. The cost of neutralization is not necessarily cost prohibitive, but the conversion of the salt to the free acid does add significant costs. If derivatives such as BDO, THF and GBL are going to be competitive from a cost perspective then low $\mathrm{pH}$ fermentation will be essential.

\subsubsection{Derivative Considerations}

A primary technology for use of succinic acid is selective reduction to give the well-known butanediol (BDO), tetrahydrofuran (THF) and gamma-butyrolactone (GBL) family. The hydrogenation/reduction chemistry for the conversion of succinic acid to BDO, THF and BGL is well known and is similar to the conversion of maleic anhydride to the same family of compounds. The only real technical consideration here is the development of catalysts that would not be affected by impurities in the fermentation. This is a significant challenge but would not necessarily be a high priority research item until the costs of the fermentation are substantially reduced. 
Pyrrolidinones are materials that can be derived from GBL, and address a large solvent market. Reaction of GBL with various amines leads to the production of materials such as pyrrolidinone and N-methylpyrrolidinone. Succinic acid can also be converted more directly to pyrrolidinones through the fermentative production of diammonium succinate. One advantage with the fermentation derived succinic acid is that the conversion of diammonium succinate to the pyrrolidones directly could offer a significant cost advantage. This would eliminate the need for low a low $\mathrm{pH}$ fermentation for the direct production of succinic acid.

Similar chemistry can be applied to transformations of malic and fumaric acid. Of particular interest is the ability to use selective reduction for the conversion of fumaric acid to succinic, and the use of malic acid in the production of substituted THF or NMP derivatives.

\subsubsection{Overall Outlook}

There is a significant market opportunity for the development of biobased products from the $\mathrm{C} 4$ building block diacids. The major challenges are primarily associated with reducing the overall cost of the fermentation. In order to competitive with petrochemicals derived products the fermentation cost needs to be at or below $\$ 0.25 /$ pound. This is a significant technical challenge and should be undertaken with a long-term perspective. When considered in aggregate, the diacid family offers access to a wide range of products that address a number of high volume chemical markets. 


\section{$9.2 \quad 2,5-F u r a n$ dicarboxylic acid (FDCA)}

\subsubsection{Pathways to Building Block from Sugars}

Table 13 -Pathways to Building Block From Sugars [ 2,5-Furan dicarboxylic Acid (FDCA)]

\begin{tabular}{|c|c|c|}
\hline Type of pathway & Technical Barriers & $\begin{array}{c}\text { Direct Uses of } \\
\text { Buflding Block }\end{array}$ \\
\hline $\begin{array}{c}\text { Chemical - Oxidative } \\
\text { dehydration of C6 } \\
\text { sugars }\end{array}$ & $\begin{array}{c}\text { Dehydration } \\
\text { Selective dehydrations without side reactions } \\
\text { Dehydration steps to anhydrides or lactones } \\
\text { New heterogeneous catalyst systems (solid } \\
\text { acid catalyst) to replace liquid catalysts } \\
\text { Oxidations }\end{array}$ & $\begin{array}{c}\text { PET analogs with } \\
\text { potentially new } \\
\text { properties (bottles, } \\
\text { films, containers) }\end{array}$ \\
\hline $\begin{array}{c}\text { Alcohols (ROH) to acids (RCOOH) } \\
\text { Avoiding exotic oxidants in favor of air, } \\
\text { oxygen, dilute hydrogen peroxide } \\
\text { Tolerance to inhibitory components of } \\
\text { biomass processing streams }\end{array}$ & \\
\hline $\begin{array}{c}\text { Biotransformation - } \\
\text { Possibly enzymatic } \\
\text { conversions }\end{array}$ & $\begin{array}{c}\text { Oxidation of aldehydes to acids and alcohols } \\
\text { to aldehydes }\end{array}$ & \\
\hline
\end{tabular}

\subsubsection{Primary Transformation Pathway(s) to Derivatives}

Table 14 - Family 1: Reduction [Primary Transformation Pathway(s) to Derivatives: 2,5Furan dicarboxylic Acid (FDCA)]

\begin{tabular}{|c|c|c|}
\hline $\begin{array}{l}\text { Derivative or } \\
\text { Derivative Family }\end{array}$ & Technical barriers & $\begin{array}{l}\text { Potential use of } \\
\text { derivatives }\end{array}$ \\
\hline Diols and Aminations & $\begin{array}{c}\text { Selective reduction of acids in presence of } \\
\text { alkenes. Direct reduction of carboxylic acids } \\
\text { to alcohols. } \\
\text { Knowledge of properties of polymer } \\
\text { derivatives }\end{array}$ & $\begin{array}{c}\text { New polyesters and } \\
\text { nylons with new } \\
\text { properties likely for } \\
\text { fiber applications }\end{array}$ \\
\hline $\begin{array}{c}\text { Levulinic and Succinic } \\
\text { Acids }\end{array}$ & Selective catalytic tools & $\begin{array}{c}\text { All uses of succinic } \\
\text { and levulinic }\end{array}$ \\
\hline
\end{tabular}


Table 15 - Family 2: Direct Polymerization [Primary Transformation Pathway(s) to Derivatives: 2,5-Furan dicarboxylic Acid (FDCA)]

\begin{tabular}{|c|c|l|}
\hline $\begin{array}{c}\text { Derivative or } \\
\text { Derivative Family }\end{array}$ & $\begin{array}{c}\text { Technical barriers } \\
\text { terephthalate analogs. }\end{array}$ & $\begin{array}{l}\text { Potential use of } \\
\text { derivatives }\end{array}$ \\
\hline Furanoic Polyamines & $\begin{array}{c}\text { Reactivity of monomer. } \\
\text { Controlling rates } \\
\text { Control of molecular weight \& properties }\end{array}$ & $\begin{array}{c}\text { Furanoic polyesters for } \\
\text { bottles, containers, } \\
\text { films, }\end{array}$ \\
& $\begin{array}{c}\text { Reactivity of monomer. } \\
\text { Controlling rates } \\
\text { Selective esterifications to control branching } \\
\text { Control of molecular weight \& properties }\end{array}$ & $\begin{array}{c}\text { Polyamide market for } \\
\text { use in new nylons }\end{array}$ \\
\hline
\end{tabular}

Building block: 2,5 - Furan dicarboxylic acid (FDCA)

$$
\begin{aligned}
& \text { Family } 1 \text { - Reduction } \\
& \text { Family } 2 \text { - Direct Polymerization }
\end{aligned}
$$

\subsubsection{Building Block Considerations}

Dehydration of the sugars available within the biorefinery can lead to a family of products, including dehydrosugars, furans, and levulinic acid. FDCA is a member of the furan family, and is formed by an oxidative dehydration of glucose. The process has been reported to proceed using oxygen, or electrochemistry. The conversion can also be carried out by oxidation of 5-hydroxymethylfurfural, which is an intermediate in the conversion of 6-carbon sugars into levulinic acid, another member of the top 10. Figure 7 describes some of the potential utility of FDCA.

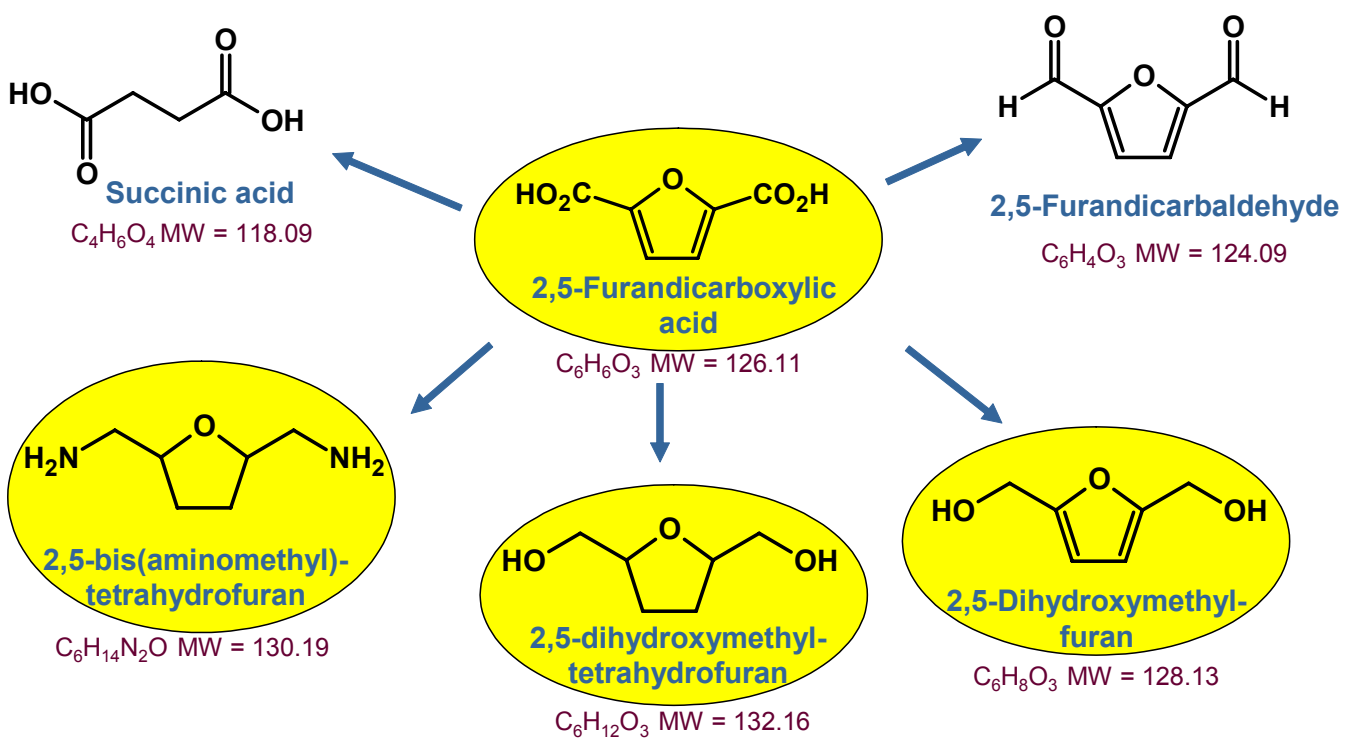

Figure 7 - Derivatives of FDCA 


\subsubsection{Derivative Considerations}

FDCA has a large potential as a replacement for terephthalic acid, a widely used component in various polyesters, such as polyethylene terephthalate (PET) and polybutyleneterephthalate (PBT). PET has a market size approaching 4 billion lb/yr, and PBT is almost a billion $\mathrm{lb} / \mathrm{yr}$. The market value of PET polymers varies depending on the application, but is in the range of $\$ 1.00-3.00 / \mathrm{lb}$ for uses as films and thermoplastic engineering polymers. The versatility of FDCA is also seen in the number of derivatives available via relatively simple chemical transformations. Selective reduction can lead to partially hydrogenated products, such as 2,5-dihydroxymethylfuran, and fully hydrogenated materials, such as 2,5-bis(hydroxymethyl)tetrahydrofuran. Both of these latter materials can serve as alcohol components in the production of new polyester, and their combination with FDCA would lead to a new family of completely biomass-derived products. Extension of these concepts to the production of new nylons, either through reaction of FDCA with diamines, or through the conversion of FDCA to 2,5-bis(aminomethyl)tetrahydrofuran could address a market of almost 9 billion $\mathrm{lb} / \mathrm{yr}$, with product values between $\$ 0.85$ and 2.20/lb, depending on the application. FDCA can also serve as a starting material for the production of succinic acid, whose utility is detailed elsewhere in this report.

The primary technical barriers to production and use of FDCA include development of effective and selective dehydration processes for sugars. The control of sugar dehydration could be a very powerful technology, leading to a wide range of additional, inexpensive building blocks, but it is not yet well understood. Currently, dehydration processes are generally nonselective, unless, immediately upon their formation, the unstable intermediate products can be transformed to more stable materials. Necessary R\&D will include development of selective dehydration systems and catalysts. FDCA formation will require development of cost effective and industrially viable oxidation technology that can operate in concert with the necessary dehydration processes.

A number of technical barriers also exist with regard to the use of FDCA (and related compounds) in the production of new polymers. Development and control of esterification reactions, and control of the reactivity of the FDCA monomer will be of great importance. Understanding the link between the discrete chemistry occurring during polymer formation, and how this chemistry is reflected in the properties of the resulting polymer will provide useful information for industrial partners seeking to convert this technology into marketplace products.

\subsubsection{Overall Outlook}

The utility of FDCA as a PET/PBT analog offers an important opportunity to address a high volume, high value chemical market. To achieve this opportunity, R\&D to develop selective oxidation and dehydration technology will need to be carried out. However, the return on investment might have applicability of interest to an important segment of the chemical industry. 


\subsection{3-Hydroxypropionic acid (3-HPA)}

9.3.1 Pathways to Building Block from Sugars

Table 16 - Pathways to Building Block from Sugars (3-HPA)

\begin{tabular}{|c|c|c|}
\hline Type of pathway & Technical Barriers & $\begin{array}{l}\text { Direct Uses of } \\
\text { Bullding Block }\end{array}$ \\
\hline \multicolumn{3}{|l|}{$\begin{array}{l}\text { Chemical - Unknown } \\
\text { or multistep, costly } \\
\text { process }\end{array}$} \\
\hline $\begin{array}{l}\text { Biotransformation- } \\
\text { Fermentation }\end{array}$ & $\begin{array}{c}\text { Being done by industry. Fermentation } \\
\text { pathway not known } \\
\text { General needs in fermentation } \\
\text { Improving microbial biocatalyst to 1) reduce } \\
\text { other acid coproducts, 2) increase yields and } \\
\text { productivities } \\
\text { Lower costs of recovery process to reduce } \\
\text { unwanted salts } \\
\text { Scale-up and system integration issues }\end{array}$ & None \\
\hline
\end{tabular}

9.3.2 Primary Transformation Pathway(s) to Derivatives

Table 17 - Family 1: Reductions [Primary Transformation Pathway(s) to Derivatives (3-HPA)

\begin{tabular}{|c|c|c|}
\hline $\begin{array}{c}\text { Derivative or } \\
\text { Derivative Family }\end{array}$ & Technical barriers & $\begin{array}{l}\text { Potential use of } \\
\text { derivatives }\end{array}$ \\
\hline 1,3 propane diol & $\begin{array}{c}\text { Selective direct reduction of carboxylic acids } \\
\text { Reduction at mild conditions - atmospheric } \\
\text { pressure, low T }\end{array}$ & $\begin{array}{c}\text { Tolerance to inhibitory elements or } \\
\text { components of biomass based feedstocks } \\
\text { robust catalysts and catalyst lifetimes }\end{array}$ \\
\hline
\end{tabular}

Table 18 - Family 2: Dehydration [Primary Transformation Pathway(s) to Derivatives (3-HPA)

\begin{tabular}{|c|c|c|}
\hline $\begin{array}{c}\text { Derivative or } \\
\text { Derivative Family }\end{array}$ & Technical barriers & $\begin{array}{l}\text { Potential use of } \\
\text { derivatives }\end{array}$ \\
\hline Acrylate family & $\begin{array}{c}\text { Selective dehydration without side reactions } \\
\text { (high value need for biomass) } \\
\text { New heterogeneous catalysts (i.e. solid acid } \\
\text { catalysts) to replace liquid catalysts and to } \\
\text { improve existing catalyst based systems }\end{array}$ & $\begin{array}{c}\text { Contact lenses, } \\
\text { diapers (Super } \\
\text { Absorbent Polymers } \\
\text { SAPs) }\end{array}$ \\
\hline
\end{tabular}

Building Block: 3-Hydroxypropionic acid (3-HPA)

Primary Derivatives:

Family 1: Reductions

Family 2: Dehydrations 
3-Hydroxypropionic acid is a C3 building block and has the potential to be a key building block for deriving both commodity and specialty chemicals. The basic chemistry of 3-HPA is not represented by a current petrochemically derived technology. The chemistry of 3-HPA to the primary families of derivatives is shown in Figure 9.

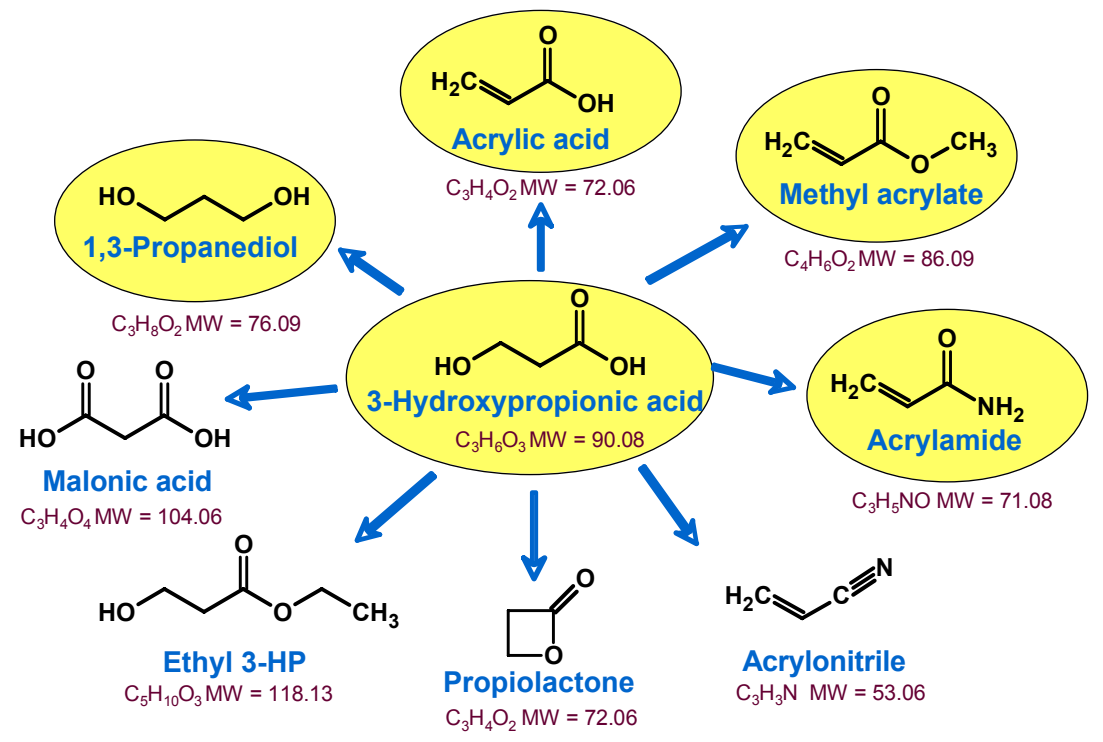

Figure 8 - Derivatives of 3-HPA

The major technical hurdles for the development of 3-HPA as a building block include the development of very low cost fermentation routes. Major technical considerations are the development of an organism with the appropriate pathways. In principle, the fermentation should be equivalent to lactic acid from a yield perspective. The major elements of improvement in the fermentation include the following considerations.

\subsubsection{Building Block Considerations}

Productivity: Productivity improvements are required to reduce the capital and operating costs of the fermentation. A minimum productivity of $2.5 \mathrm{~g} / \mathrm{Lhr}$. needs to be achieved in order to economically competitive.

Pathway Engineering: It will be necessary to engineer the appropriate pathway in an organism to produce 3-HPA. If successful the yield of the fermentation should be equivalent to lactic acid.

Nutrient Requirements: It is essential for commercial fermentations to be run using minimal nutrients. Expensive nutrient components such as yeast extract and biotin must be eliminated. The nutrient requirements should be limited to the use of corn steep liquor or equivalent if at all possible.

Final Titer: Final titer is also important when considering overall process costs. This is not a showstopper but a high final titer will reduce overall separation and concentrating costs. 
pH Considerations: In an ideal situation the fermentation could be run at low $\mathrm{pH}$, most preferably without requiring any neutralization. The cost of neutralization is not necessarily cost prohibitive, the conversion of the salt to the free acid does add significant costs. If derivatives such as BDO, THF and GBL are going to be competitive from a cost perspective then low $\mathrm{pH}$ fermentation will be essential.

\subsubsection{Derivative Considerations}

\section{Family 1: 1,3-PDO}

The hydrogenation/reduction chemistry for the conversion of 3-HPA to 1,3-PDO will require the development of new catalyst systems that are capable of the direct reduction of carboxylic acid groups to alcohols. A second option is to esterify the acid to an ester and reduce the ester. This may be technically easier but will add costs to the process. 1,3-PDO has been widely publicized by DuPont as a potential monomer for use in fibers for carpet. The new properties imparted by 1,3-PDO include better dye ability, and improved elasticity. Direct reduction of 3-HPA from a fermentation broth will require the development of robust catalysts that are not susceptible to fouling from impurities.

\section{Family 2: Acrylates}

The dehydration of 3-HPA to the family of acrylates including acrylic acid and acrylamide will require the development of new acid catalyst systems that afford high selectivity. In addition, there is the potential for polymerization and this must be avoided during the dehydration. One advantage for the production of acrylamide is that the starting material could be ammonium 3-HPA. Starting with ammonium 3-HPA would eliminate the need for low pH fermentation.

\subsubsection{Overall Outlook}

There is a significant market opportunity for the development of biobased products from the C3 building block 3-HPA. The major challenges include the development of a low cost fermentation and a family of catalysts for the conversion of 3-HPA to desired products. In order to be competitive with petrochemical routes to acrylates both the fermentation and catalysis must afford high yields.

\subsection{Aspartic acid}

\subsubsection{Pathways to Building Block}

Table 19 - Pathways to Building Block - Aspartic Acid

\begin{tabular}{|c|c|c|}
\hline Type of pathway & Technical Barriers & $\begin{array}{c}\text { Direct Uses of } \\
\text { Butlding Block }\end{array}$ \\
\hline $\begin{array}{c}\text { Chemical - Amination } \\
\text { of fumaric acid with } \\
\text { ammonia }\end{array}$ & Asymmetric aminations & $\begin{array}{c}\text { Salts for chelating } \\
\text { agent. Sweeteners }\end{array}$ \\
\hline
\end{tabular}




\begin{tabular}{|c|c|c|}
\hline Type of pathway & Technical Barriers & $\begin{array}{c}\text { Direct Uses of } \\
\text { Butlding Block }\end{array}$ \\
\hline $\begin{array}{c}\text { Biotransformation - } \\
\text { Conversion of } \\
\text { oxaloacetate in the } \\
\text { Krebs cycle can yield } \\
\text { aspartic acid either } \\
\text { fermentatively or via } \\
\text { enzymatic conversion }\end{array}$ & $\begin{array}{c}\text { Pathway engineering of biocatalytic organisms to } \\
\text { overproduce oxaloacetate without compromising } \\
\text { viability of organism }\end{array}$ & \\
& $\begin{array}{c}\text { Managing operating environment } \\
\text { Enzymatic oxidation of oxaloacetate } \\
\text { Need for low cost recovery } \\
\text { Low cost sugars }\end{array}$ & \\
\hline
\end{tabular}

\subsubsection{Primary Transformation Pathway(s) to Derivatives}

Table 20 - Family 1: Reductions [Primary Tansformation Pathway(s) to Derivatives - Aspartic Acid

\begin{tabular}{|c|c|c|}
\hline $\begin{array}{c}\text { Derivative or } \\
\text { Derivative Family }\end{array}$ & Technical barriers & $\begin{array}{c}\text { Potential use } \\
\text { of derivatives }\end{array}$ \\
\hline $\begin{array}{c}\text { Amine butanediol, } \\
\text { amine tetrahydrofuran, } \\
\text { amine (-butyrolactone }\end{array}$ & $\begin{array}{c}\text { Analogous to those for succinic, malic, and } \\
\text { fumaric transformations: } \\
\text { Selective reductions } \\
\text { Operation at mild conditions (atmospheric } \\
\text { pressure, low T, etc.) } \\
\text { Catalyst tolerance to inhibitory compounds } \\
\text { acceptable catalyst lifetimes }\end{array}$ & $\begin{array}{c}\text { Amino analogs of } \\
\text { C4 } 1,4 \text { dicarboxylic } \\
\text { acids }\end{array}$ \\
\hline
\end{tabular}

Table 21 -Family 2: Dehydration - [Primary Tansformation Pathway(s) to Derivatives Aspartic Acid]

\begin{tabular}{|c|c|c|}
\hline $\begin{array}{l}\text { Derivative or } \\
\text { Derivative Family }\end{array}$ & Technical barriers & $\begin{array}{c}\text { Potential use } \\
\text { of derivatives }\end{array}$ \\
\hline Aspartic anhydride & $\begin{array}{c}\text { Selective dehydrations without side reactions } \\
\text { New heterogeneous catalyst systems (solid acid } \\
\text { catalyst) to replace liquid catalyst systems }\end{array}$ & New area \\
\hline
\end{tabular}

Table 22 - Family 3: Direct Polymerization [Primary Tansformation Pathway(s) to Derivatives - Aspartic Acid

\begin{tabular}{|c|c|c|}
\hline $\begin{array}{l}\text { Derivative or } \\
\text { Derivative Family }\end{array}$ & Technical barriers & $\begin{array}{c}\text { Potential use } \\
\text { of derivatives }\end{array}$ \\
\hline Polyaspartic & $\begin{array}{c}\text { Selective esterifications to control branching } \\
\text { Control of molecular weight \& properties }\end{array}$ & New area \\
\hline
\end{tabular}




\section{Primary Derivatives:}

\section{Family 1: Selective Reductions}

Family 2: Dehydration to anhydrides

Family 3: Direct Polymerizations

Aspartic acid is a 4-carbon amino acid that is an essential part of metabolism among many species, including humans, for protein production. There are several configurations of aspartic acid produced; however, L-aspartic is by far the most common. L-aspartic acid is primarily used to produce aspartame, a synthetic sweetener. The chemistry of aspartic acid to the primary families of derivatives is shown in Figure 9.

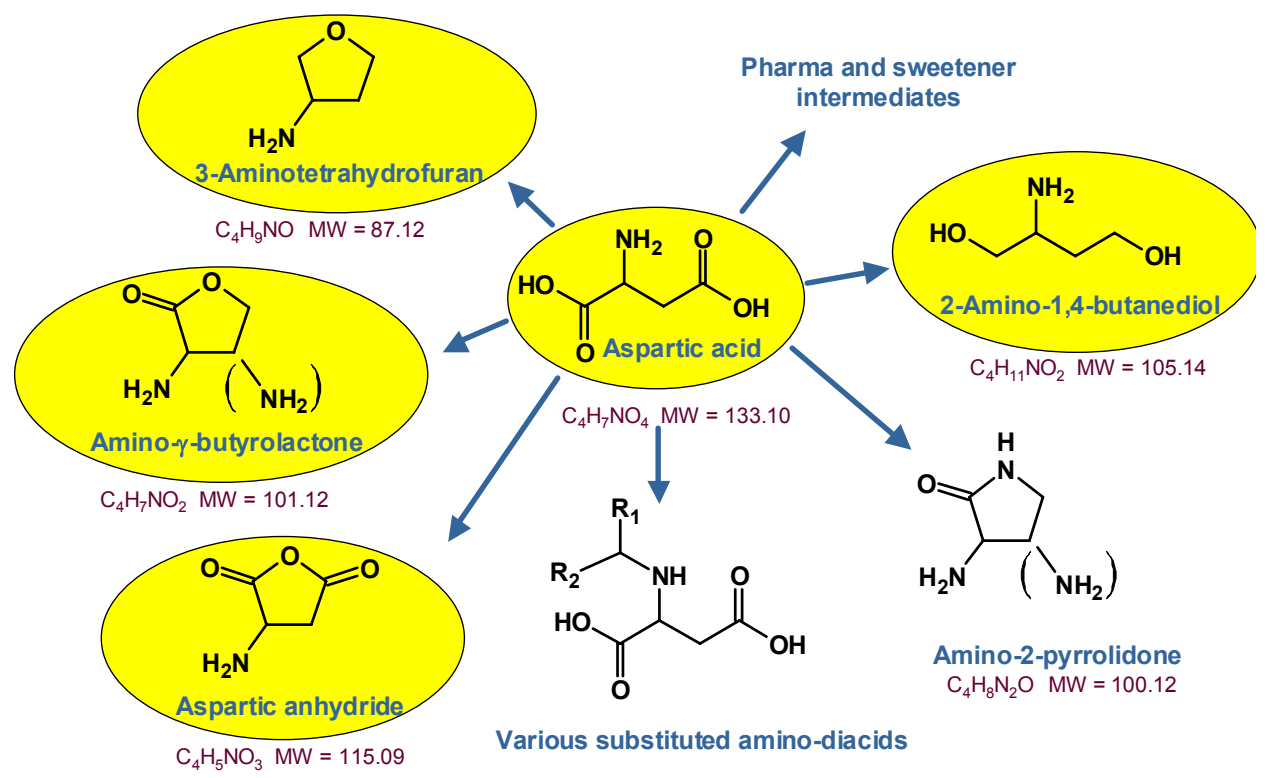

Figure 9 - Aspartic Acid Chemistry to Derivatives

There are 4 primary routes to producing L-aspartic acid: 1) chemical synthesis, 2) protein extraction, 3) fermentation, and 4) enzymatic conversion. The preferred method currently is the enzymatic route, reacting ammonia with fumaric acid, catalyzed by a lyase enzyme. The advantages to this pathway include high product concentration, high productivity, fewer byproducts, and ease of separation (crystallization).

The major technical hurdles for the development of aspartic acid as a building block involve developing a direct fermentation route (using sugar substrate) that is cost-competitive with the existing enzymatic conversion process. Direct fermentation routes are not costcompetitive yet, but the use of biotechnology holds promise to overcome this obstacle. A second strategy for reducing the cost of aspartic acid is to make improvements to the current technology. The primary focus of this effort would be to reduce the cost of fumaric acid, which is currently used as the feedstock for producing aspartic acid.

\subsubsection{Building Block Considerations}

High fermentation yields and product recovery are the two primary technical goals to strive for. A direct fermentation using sugar substrate could potentially be cheaper than fumaric 
acid and ammonia feedstocks if the production technical performance can be improved. Bayer AG also has a competing route using maleic anhydride that may be potentially cheaper. Producing fumaric acid at a lower cost could have a near term impact on reducing the cost of aspartic acid. This strategy would have the advantage of using existing capital and infrastructure.

Productivity: Productivity improvements are required to reduce the capital and operating costs of the fermentation. The existing enzyme route through fumaric acid achieves productivities which are satisfactory for specialty applications. But for commodity-scale applications further improvements in productivity will be required.

Separation/recovery costs: The cost of separating aspartic acid from the fermentation broth could be a potential showstopper. The competing enzymatic route with ammonia and fumaric has high product concentration and uses crystallization to easily separate the final product. However, crystallization can be an expensive processing step and fermentation broth separation techniques may be able to compete through research.

Final Titer: Final titer is very important when considering overall process costs. A high final titer will reduce overall separation and concentrating costs.

Nutrient Requirements: If low-cost nutrients can be used, the production economics of aspartic acid can be significantly reduced.

\subsubsection{Derivative Considerations}

\section{Family 1: Amino analogs of C4-dicarboxylic acids}

Selective reduction of the carboxylic acids of aspartic acid would produce analogs to current high volume chemicals such as 1,4-butanediol, tetrahydrofuran and gamma-butyrolactone. These analogs have the potential for large market polymer and solvent applications. The specific technology drivers are developing the ability to selectively reduce the carboxylic acids in the presence of amine groups. The ability to do this in high selectivity and under mild conditions could make the derivatives competitive with the analog C4 compounds.

\section{Family 2: Anhydrides}

The selective dehydration to form the anhydrides is generally considered to be a thermal process in the presence of an acid-based catalyst. Development of new catalysts that allow for selective dehydration without side reactions will be critical for low cost anhydride formation.

\section{Family 3: Direct polymerization to new polymers}

Synthesis of biodegradable specialty polymers - polyaspartic acid and polyaspartates (PAA) would be substitutes for polyacrylic acid and polycarboxylates. This synthesis is not expected to be difficult, but has not been undertaken. The polymerization would be analogous to polyglutamic acid that is a commercial process. 


\subsubsection{Overall Outlook}

Improved fermentation for the direct production of aspartic acid or improved fermentation for reducing the costs of fumaric acid will depend on the utilization of both genetic engineering and traditional strain improvement technology.

The L-aspartic market is expected to grow 2-3\% annually worldwide between now and 2006. New biodegradable specialty polymers (polyaspartic acid and polyaspartates) offer new potential markets as substitutes for polyacrylic acid and polycarboxylates. Applications may include detergents, water treatment systems, corrosion inhibition, and super-absorbent polymers. 


\section{$9.5 \quad$ Glucaric acid}

\subsubsection{Pathways to Building Block From Sugars}

Table 23 - Pathway to Building Block From Sugars [Glucaric Acid]

\begin{tabular}{|c|c|c|}
\hline Type of pathway & Technical Barriers & $\begin{array}{c}\text { Direct Uses of } \\
\text { Bullding Block }\end{array}$ \\
\hline $\begin{array}{c}\text { Chemical- One step } \\
\text { nitric acid oxidation of } \\
\text { starch or } \\
\begin{array}{c}\text { Catalytic oxidation of } \\
\text { starch with bleach } \\
\text { (basic) }\end{array}\end{array}$ & $\begin{array}{c}\text { Selective oxidation of alcohols (ROH) to } \\
\text { acids (RCOOH) } \\
\text { Avoiding exotic oxidants in favor of air, } \\
\text { oxygen, dilute hydrogen peroxide. } \\
\text { Lowering concentrations of oxidants } \\
\text { Development of heterogeneous catalyst } \\
\text { systems }\end{array}$ & $\begin{array}{c}\text { Tolerance to inhibitory elements of biomass } \\
\text { based feedstocks }\end{array}$ \\
\hline $\begin{array}{c}\text { Biotransformation- Not } \\
\text { known }\end{array}$ & & \\
\hline
\end{tabular}

9.5.2 Primary Transformation Pathway(s) to Derivatives

Table 24 - Family 1 - Dehydration [Primary Transformation Pathway(s) to Derivatives Glucaric Acid]

\begin{tabular}{|c|c|c|}
\hline $\begin{array}{c}\text { Derivative or } \\
\text { Derivative Family }\end{array}$ & Technical barriers & $\begin{array}{l}\text { Potential use of } \\
\text { derivatives }\end{array}$ \\
\hline Lactones & $\begin{array}{c}\text { Selective dehydration without side reactions } \\
\text { Dehydration to anhydrides or lactones } \\
\text { New heterogeneous catalysts (i.e. solid acid } \\
\text { catalysts) to replace liquid catalysts and to } \\
\text { improve existing catalyst based systems }\end{array}$ & \\
\hline
\end{tabular}

Table 25 - Amination and Direct Polymeriation [Primary Transformation Pathway(s) to Derivatives - Glucaric Acid]

\begin{tabular}{|c|c|c|}
\hline $\begin{array}{c}\text { Derivative or } \\
\text { Derivative Family }\end{array}$ & Technical barriers & $\begin{array}{l}\text { Potential use of } \\
\text { derivatives }\end{array}$ \\
\hline $\begin{array}{c}\text { Polyglucaric esters and } \\
\text { amides }\end{array}$ & $\begin{array}{c}\text { Manage rates } \\
\text { Selective esterifications to control branching } \\
\text { Control of molecular weight \& properties }\end{array}$ & $\begin{array}{c}\text { Nylons or different } \\
\text { properties (i.e., like } \\
\text { Kevlar vs. carpet fiber) }\end{array}$ \\
\hline
\end{tabular}


Building Block: Glucaric Acid

Family 1 - Dehydration

Family 2 - Direct Polymerization

\subsubsection{Building Block Considerations}

Glucaric acid is a member of a much larger family of materials known as oxidized sugars. These materials represent a significant market opportunity. For example, oxidation of glucose to glucanic acid (worldwide consumption, 92 million lb in 1998; F. Dubois, A. DeBoo, A. Kishi, Chemical Economics Handbook, "Chelating Agents", 515.5000, March 2000) can be carried out using chemical or biochemical catalysis in high yield.

In contrast, production of glucaric acid as a building block is more difficult. However, the value to the biorefinery of converting cheap glucose into glucaric acid arises from two features: 1) glucaric acid can serve as a starting point for the production of a wide range of products with applicability in high volume markets and 2) development of efficient processes for production of glucaric acid will also be applicable to efficient oxidation of other inexpensive sugars studied in this evaluation, such as xylose or arabinose. Glucaric can be produced from glucose by oxidation with nitric acid. Error! Reference source not found. summarizes the product and its derivative opportunities.

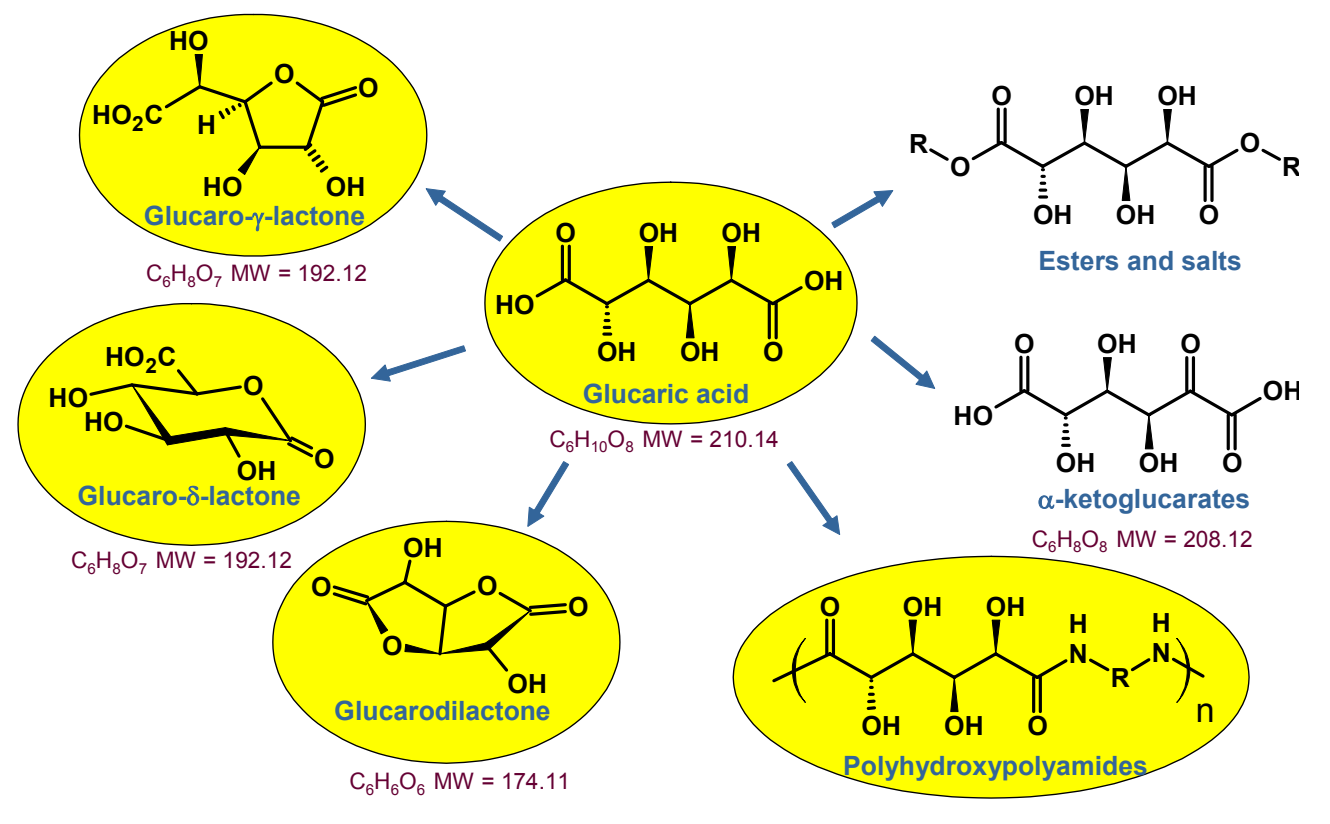

Figure 10- Derivatives of Glucaric Acid

\subsubsection{Derivative Considerations}

Ready availability of aldaric acids would form the basis of a new family of renewable building blocks derived from carbohydrates. A significant opportunity exists in the production of new nylons (polyhydroxypolyamides). The combination of cheap glucose with currently available diamines could address a market of over 9 billion $\mathrm{lb} / \mathrm{yr}$ with values between $\$ 0.85$ and $\$ 2.20 / \mathrm{lb}$, depending on application. Glucaric acid (and its esters) is also a potential starting 
material for new types of hyperbranched polyesters addressing markets of similar sizes to nylons with a similar value structure. Finally, glucaric acid could also address the very large detergent surfactant market, as it should exhibit useful chelating properties for cations. Simple chemical transformation will lead to $\alpha$-ketoglucarates, starting points for the production additional types of new polymeric materials. It is important to note that success with glucaric acid is not limited to the use of glucose alone. Rather, technology development for this material will be directly applicable to a wide range of other materials evaluated in this analysis, including xylose, arabinose, and glycerol. A very wide range of products and opportunities will be available from an investment in glucaric acid R\&D.

The technical barriers for this work include development of efficient and selective oxidation technology for glucose, and eliminating the need to use nitric acid as the oxidant. Recent work indicates that new catalytic processes using inexpensive oxidants may pave the way for high yield production of glucaric acid from glucose. Further technical barriers include development of selective methods for sugar dehydration to transform glucaric into sugar lactones, particularly glucaric dilactone, an analog of isosorbide, another compound included in this evaluation.

\subsubsection{Overall Outlook}

Selective oxidation of an inexpensive sugar or sugar source to a single compound is analogous to conversion of complex starting petrochemicals to single and much simpler building blocks. Success in development of glucaric acid production and new derivatives will have broad application to the sugar platform and will address high volume and high value markets. Technology specific to glucaric acid will also be applicable to the production of xylaric and arabinaric acids, two other compounds ranked highly within this evaluation, making this portion of the biorefinery R\&D effort significant. 


\subsection{Glutamic acid}

9.6.1 Pathways to Building Block From Sugars

Table 26 - Pathways to Building Block From Sugars [Glutamic Acid]

\begin{tabular}{|c|c|c|}
\hline Type of pathway & Technical Barriers & $\begin{array}{l}\text { Direct Uses of } \\
\text { Buflding Block }\end{array}$ \\
\hline Chemical- None & & \\
\hline $\begin{array}{l}\text { Biotransformation- } \\
\text { Fermentation product }\end{array}$ & $\begin{array}{c}\text { Improving microbial biocatalyst to 1) } \\
\text { reduce other acid coproducts, 2) } \\
\text { increase yields and productivities } \\
\text { Better control of operating } \\
\text { environment } \\
\text { Lower costs of recovery process to } \\
\text { reduce unwanted salts } \\
\text { Scale-up and system integration } \\
\text { issues }\end{array}$ & \\
\hline
\end{tabular}

9.6.2 Primary Transformation Pathway(s) to Derivatives

Table 27 - Family 1: Reductions [Primary Transformation Pathway(s) to Derivatives Glutamic Acid]

\begin{tabular}{|c|c|c|}
\hline $\begin{array}{c}\text { Derivative or Derivative } \\
\text { Family }\end{array}$ & Technical barriers & $\begin{array}{l}\text { Potential use of } \\
\text { derivatives }\end{array}$ \\
\hline $\begin{array}{c}\text { Diols (1,5-propanediol), } \\
\text { diacids (1,5-propanediacid), } \\
\text { aminodiol (5-amino, 1-butanol) }\end{array}$ & $\begin{array}{c}\text { Selective deamination, reduction and } \\
\text { reductive deamination } \\
\text { Reduction at mild conditions - } \\
\text { atmospheric pressure, low T } \\
\text { Managing acid salts }\end{array}$ & $\begin{array}{c}\text { Monomers for } \\
\text { polyesters and } \\
\text { polyamides. }\end{array}$ \\
& $\begin{array}{c}\text { Tolerance to inhibitory elements or } \\
\text { components of biomass based } \\
\text { feedstocks- robust catalysts }\end{array}$ & \\
\hline
\end{tabular}

Building Block: Glutamic Acid

Primary Derivatives:

Family 1: Hydrogenation/Reduction

Glutamic acid is a five-carbon amino acid and has the potential to be a novel building block for five carbon polymers. The building block and its derivatives have the potential to build similar polymers but with new functionality to derivatives of the petrochemicals derived from maleic anhydride. These polymers could include polyesters and polyamides. The chemistry of glutamic acid and the routes to the primary families of derivatives is shown in Figure 11. 


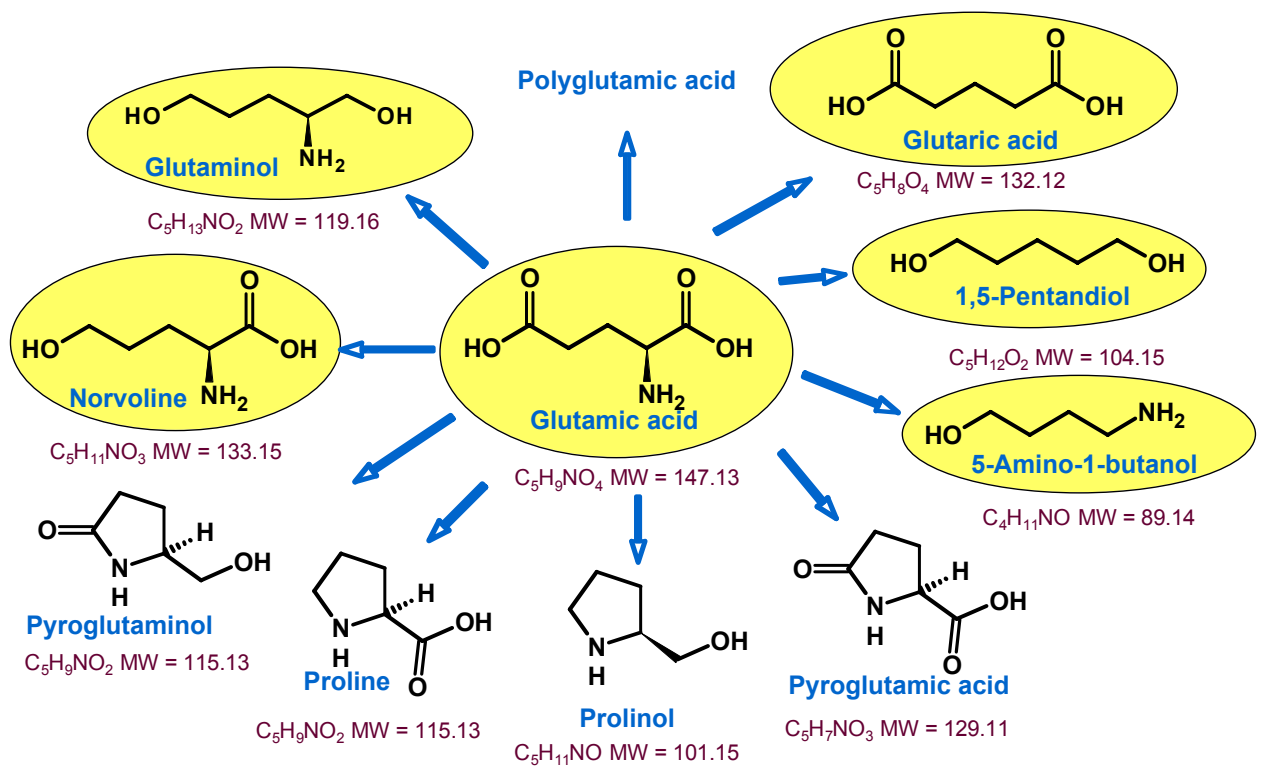

Figure 11 - Glutamic Acid and its Derivatives

The major technical hurdles for the development of glutamic acid as a building block include the development of very low cost fermentation routes. There are currently several fermentation routes for the production of sodium glutamate (MSG). These routes are all based on the production of the sodium salt. One of the major challenges for the development of a low cost fermentation is to develop an organism that can produce glutamic acid as the free acid. This would eliminate the need for neutralization and substantially reduce the costs of purification and conversion of the sodium salt to the free acid. Additional improvements in the fermentation would include increasing the productivity of the organism and improving final fermentation titer.

General considerations for production of the derivatives include the ability to do selective dehydrogenation (reduction) in the presence of other functionalities, specifically the conversion of the acid moieties to alcohols in the presence of amines. This will require the development of new heterogeneous catalyst systems that afford high selectivity, fast reaction rates and moderate operating conditions.

\subsubsection{Building Block Considerations}

Productivity: Productivity improvements are required to reduce the capital and operating costs of the fermentation. A minimum productivity of $2.5 \mathrm{~g} / \mathrm{Lhr}$ needs to be achieved in order to be economically competitive on a commodity scale.

Nutrient Requirements: It is essential for commercial fermentations to be run using minimal nutrients. Expensive nutrient components such as yeast extract and biotin must be eliminated. The nutrient requirements should be limited to the use of corn steep liquor or equivalent if possible. 
Final Titer: Final titer is also important when considering overall process costs. This is not a showstopper but a high final titer will reduce overall separation and concentrating costs.

pH Considerations: Ideally, the fermentation could be run at low $\mathrm{pH}$, most preferably without requiring any neutralization. The cost of neutralization is not necessarily cost prohibitive, but the conversion of the salt to the free acid does add significant costs. If derivatives are going to be competitive from a cost perspective then low $\mathrm{pH}$ fermentation will be essential.

\subsubsection{Derivative Considerations}

\section{Family 1: Glutaminol, 5-amino-1-butanol, 1,5-pentanediol, norvoline}

The hydrogenation/reduction chemistry for the conversion of glutamic acid to the analogs of BDO, THF and BGL needs substantial development. The chemistry for doing selective reductions is not well understood, particularly in aqueous media. The technical challenge will be to develop new catalyst systems to obtain high yields of desired products and limit side reactions involving the other functionalities such as the amine. An additional consideration is the development of catalysts that would not be affected by impurities in the fermentation. This is a significant challenge and should be considered early in the development cycle since commercial fermentations for glutamic acid are available.

\subsubsection{Overall Outlook}

There is a significant market opportunity for the development of biobased products from the C5 building block glutamic acid. The major challenges are primarily associated with reducing the overall cost of the fermentation. In order to be competitive with products derived from petrochemicals, the fermentation cost needs to be at or below $\$ 0.25 /$ pound. This is a significant technical challenge but has the potential to be obtained in the midterm since there is substantial experience working with the organism for glutamic acid. 


\section{$9.7 \quad$ Itaconic acid}

\subsubsection{Pathways to Building Blocks from Sugars}

Table 28 - Pathways to Building Block from Sugars [Itaconic Acid]

\begin{tabular}{|c|c|c|}
\hline Type of pathway & Technical Barriers & $\begin{array}{c}\text { Direct Uses of } \\
\text { Buflding Block }\end{array}$ \\
\hline $\begin{array}{c}\text { Chemical- Multistep. Not likely } \\
\text { a viable option }\end{array}$ & $\begin{array}{c}\text { Costly synthesis. Reducing number of } \\
\text { steps }\end{array}$ & $\begin{array}{c}\text { Copolymers with } \\
\text { styrene-butadiene } \\
\text { polymers }\end{array}$ \\
\hline Biotransformation- & $\begin{array}{c}\text { Improving microbial biocatalyst to 1) } \\
\text { reduce other acid coproducts, 2) } \\
\text { increase yields and productivities } \\
\text { Better control of operating } \\
\text { environment }\end{array}$ & $\begin{array}{c}\text { Copolymer in styrene } \\
\text { butadiene polymers } \\
\text { (provides dye } \\
\text { receptivity for fibers); } \\
\text { Nitrile latex }\end{array}$ \\
& Lower costs of recovery process \\
& Scale-up and system integration & \\
\hline
\end{tabular}

\subsubsection{Primary Transformation Pathway(s) to Derivatives}

Table 29 - Family 1: Reductions [ Primary Transformation Pathway(s) to Derivatives Itaconic Acid]

\begin{tabular}{|c|c|c|}
\hline $\begin{array}{c}\text { Derivative or Derivative } \\
\text { Family }\end{array}$ & Technical barriers & $\begin{array}{l}\text { Potential use of } \\
\text { derivatives }\end{array}$ \\
\hline $\begin{array}{c}\text { Methyl butanediol, } \\
\text { family }\end{array}$ & $\begin{array}{c}\text { Selective reduction of specific } \\
\text { functionalities } \\
\text { Reduction at mild conditions - } \\
\text { atmospheric pressure, low T } \\
\text { Tolerance to inhibitory elements or } \\
\text { components of biomass based } \\
\text { feedstocks- robust catalysts }\end{array}$ & $\begin{array}{c}\text { May confer new useful } \\
\text { properties for the } \\
\text { BDO, GBL, and THF } \\
\text { family of polymers }\end{array}$ \\
\hline Pyrrolidinones & $\begin{array}{c}\text { Same as above including amination } \\
\text { issues }\end{array}$ & $\begin{array}{c}\text { Solvents and polymer } \\
\text { precursor }\end{array}$ \\
\hline
\end{tabular}

Table 30 - Family 2: Direct Polymerization [ Primary Transformation Pathway(s) to Derivatives - Itaconic Acid]

\begin{tabular}{|c|c|c|}
\hline $\begin{array}{c}\text { Derivative or Derivative } \\
\text { Family }\end{array}$ & Technical barriers & $\begin{array}{c}\text { Potential use } \\
\text { of derivatives }\end{array}$ \\
\hline Polyitaconic & $\begin{array}{c}\text { Manage rates } \\
\text { Selective esterifications to control } \\
\text { branching } \\
\text { Control of molecular weight \& properties }\end{array}$ & $\begin{array}{c}\text { New polymer } \\
\text { opportunity }\end{array}$ \\
\hline
\end{tabular}


Building Block: Itaconic Acid

Primary Derivatives:

Family 1: Reduction

Family 2: Direct Polymerization

\subsubsection{Building Block Considerations}

Itaconic acid is a C5 dicarboxylic acid, also known as methyl succinic acid and has the potential to be a key building block for deriving both commodity and specialty chemicals. The basic chemistry of itaconic acid is similar to that of the petrochemicals derived maleic acid/anhydride. The chemistry of itaconic acid to the primary families of derivatives is shown in Figure 12.

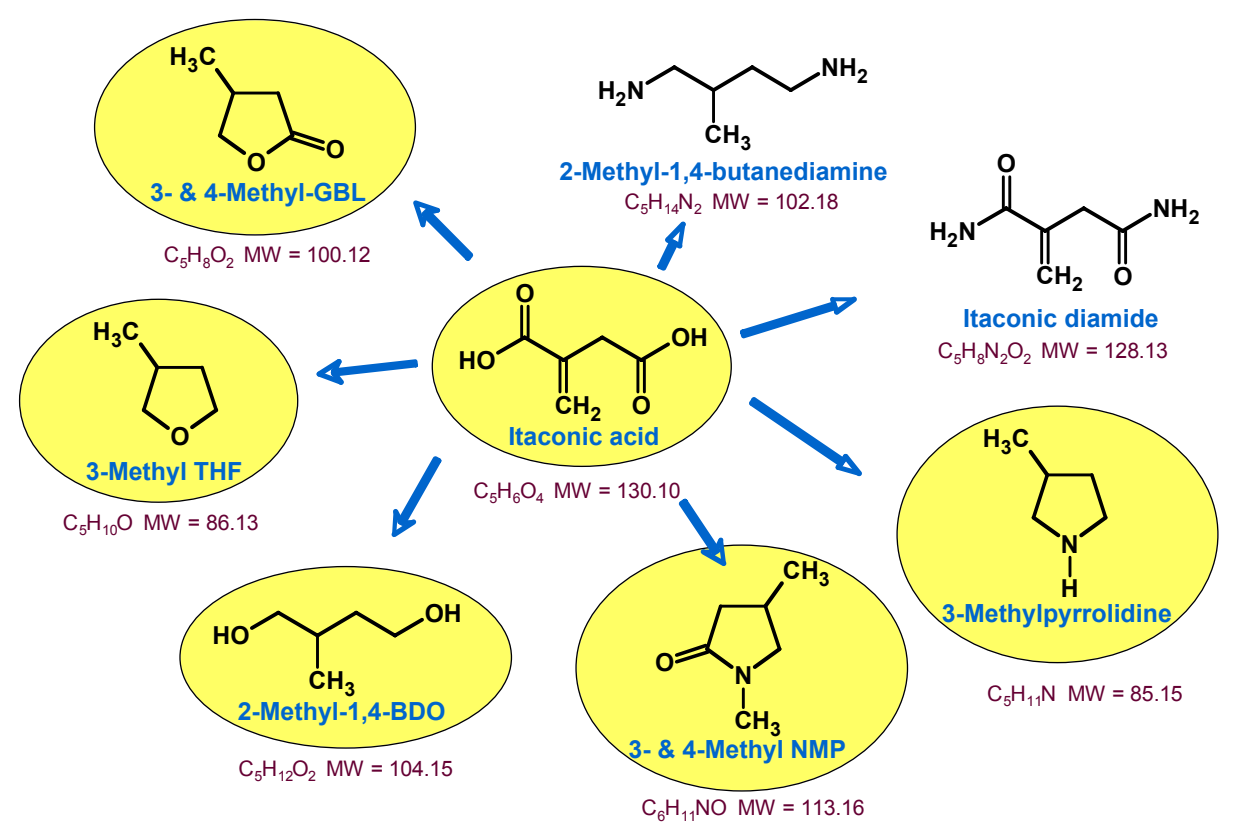

Figure 12- Itaconic Acid Chemistry to Derivatives

Itaconic acid is currently produced via fungal fermentation and is used primarily as a specialty monomer. The major applications include the use as a copolymer with acrylic acid and in styrene-butadiene systems. The major technical hurdles for the development of itaconic acid as a building block for commodity chemicals include the development of very low cost fermentation routes. The primary elements of improved fermentation include increasing the fermentation rate, improving the final titer and potentially increasing the yield from sugar. There could also be some cost advantages associated with an organism that could utilize both $\mathrm{C} 5$ and $\mathrm{C} 6$ sugars.

Productivity: Productivity improvements are required to reduce the capital and operating costs of the fermentation. A minimum productivity of $2.5 \mathrm{~g} / \mathrm{Lhr}$ needs to be achieved in order to economically competitive. 
Nutrient Requirements: It is essential for commercial fermentations to be run using minimal nutrients. Expensive nutrient components such as yeast extract and biotin must be eliminated. The nutrient requirements should be limited to the use of corn steep liquor or equivalent if at all possible.

Final Titer: Final titer is also important when considering overall process costs. This is not a showstopper but a high final titer will reduce overall separation and concentrating costs.

pH Considerations: Ideally, fermentation could be run at low $\mathrm{pH}$, most preferably without requiring any neutralization. The cost of neutralization is not necessarily cost prohibitive, the conversion of the salt to the free acid does add significant costs. If derivatives such as 2methyl-1,4-BDO, 3-methyl-THF, 3- or 4-GBL, and 2-methyl-1,4-butanediamine are going to be competitive from a cost perspective then low $\mathrm{pH}$ fermentation will be essential.

\subsubsection{Derivative Considerations}

\section{Family 1: 2-Methyl-1,4-BDO, 3-Methyl THF, 3-\&4-GBL, 2-Methyl-1,4-butanediamine}

The hydrogenation/reduction chemistry for the conversion of itaconic acid to 2-methyl-1,4BDO, 3-methyl THF, 3- and 4-GBL, and 2-methyl-1,4-butanediamine is not well known but should be similar to that of the hydrogenation chemistry associated with the production of $\mathrm{BDO}$, THF and GBL from maleic anhydride. One technical consideration here is the development of catalysts that would not be affected by impurities in the fermentation.

\section{Family 1: Pyrrolidones}

The conversion of itaconic acid to pyrrolidones could follow the same chemistry associated with the conversion of GBL to pyrrolidones. One advantage with the fermentation-derived succinic acid is that the conversion of diammonium itaconate to the pyrrolidones directly could offer a significant cost advantage. This would eliminate the need for low $\mathrm{pH}$ fermentation for the direct production of itaconic acid.

\section{Family 2: Direct Polymerization}

The potential for direct polymerization would need to be investigated. The similarities of polyitaconic properties to known polymers would need to be ascertained in order to evaluate its use as a polymer. Its novel functionalities make it a potential raw material for polyene type polymers (polyvinylitaconic with side chains).

\subsubsection{Overall Outlook}

There is a significant market opportunity for the development of biobased products from the C5 building block itaconic acid. The major challenges are primarily associated with reducing the overall cost of the fermentation. In order to be competitive with petrochemical-derived products the fermentation cost needs to be at or below $\$ 0.25 /$ pound. This is a significant technical challenge and should be undertaken with a long-term perspective. 


\section{$9.8 \quad$ Levulinic acid}

\subsubsection{Pathways to Building Block From Sugars}

Table 31 - Pathways to Building Block From Sugars [Levulinic Acid]

\begin{tabular}{|c|c|c|}
\hline Type of pathway & Technical Barriers & $\begin{array}{c}\text { Direct Uses of } \\
\text { Buflding Block }\end{array}$ \\
\hline $\begin{array}{c}\text { Chemical - One step, acid } \\
\text { catalyzed dehydration and } \\
\text { decomposition of cellulosics } \\
\text { and sugars }\end{array}$ & $\begin{array}{c}\text { Selective dehydration without side } \\
\text { reactions (high value need for biomass) } \\
\text { New heterogeneous catalysts (i.e., solid } \\
\text { acid catalysts) to replace liquid catalysts } \\
\text { and to improve existing catalyst based } \\
\text { systems }\end{array}$ & $\begin{array}{c}\text { system } \\
\text { Biotransformation- None }\end{array}$ \\
\hline
\end{tabular}

\subsubsection{Primary Transformation Pathway(s) to Derivatives}

Table 32 - Family 1: Reductions [Primary Transformation Pathways(s) to Derivatives Levulinic Acid]

\begin{tabular}{|c|c|c|}
\hline $\begin{array}{c}\text { Derivative or } \\
\text { Derivative Family }\end{array}$ & Technical barriers & $\begin{array}{c}\text { Potential use of } \\
\text { derivatives }\end{array}$ \\
\hline $\begin{array}{c}\text { Methyl tetrahydrofuran, }(\gamma- \\
\text { butyrolactone (some of this } \\
\text { technology is already } \\
\text { patented) }\end{array}$ & $\begin{array}{c}\text { Selective reduction of diacids to produce } \\
\text { alcohols, lactones and furans } \\
\text { Reduction at mild conditions - pressure, } \\
\text { low T }\end{array}$ & $\begin{array}{c}\text { Fuel oxygenates, } \\
\text { solvents }\end{array}$ \\
& $\begin{array}{c}\text { Tolerance to inhibitory elements or } \\
\text { components of biomass based } \\
\text { feedstocks (sugar streams) - robust } \\
\text { catalysts }\end{array}$ & \\
\hline
\end{tabular}

Table 33 - Family 2: Oxidations [Primary Transformation Pathways(s) to Derivatives Levulinic Acid]

\begin{tabular}{|c|c|c|}
\hline $\begin{array}{c}\text { Derivative or } \\
\text { Derivative Family }\end{array}$ & Technical barriers & $\begin{array}{l}\text { Potential use of } \\
\text { derivatives }\end{array}$ \\
\hline Acetic-acrylic succinic acids & $\begin{array}{c}\text { Selective oxidation of alcohols (ROH) to } \\
\text { acids (RCOOH) } \\
\text { Avoiding exotic oxidants in favor of air, } \\
\text { oxygen, dilute hydrogen peroxide. } \\
\text { Lowering concentrations of oxidants } \\
\text { required (safety issue) } \\
\text { Tolerance to inhibitory elements of } \\
\text { biomass based feedstocks (sugar } \\
\text { streams) }\end{array}$ & $\begin{array}{c}\text { Copolymerization with } \\
\text { other moners for } \\
\text { propenty }\end{array}$ \\
\hline
\end{tabular}




\begin{tabular}{|l|l|l|}
\hline $\begin{array}{l}\text { Derivative or } \\
\text { Derivative Family }\end{array}$ & $\begin{array}{l}\text { Pechnical barriers } \\
\text { derivatives }\end{array}$ \\
\hline & $\begin{array}{c}\text { Facile and selective conversion of } \\
\text { aldehydes to acids and alcohols to } \\
\text { aldehydes } \\
\text { Enzymatic oxidation requires cofactors }\end{array}$ & \\
\hline
\end{tabular}

Table 34 - Family 3: Condensation [Primary Transformation Pathways(s) to Derivatives Levulinic Acid]

\begin{tabular}{|c|c|c|}
\hline $\begin{array}{c}\text { Derivative or } \\
\text { Derivative Family }\end{array}$ & Technical barriers & $\begin{array}{l}\text { Potential use of } \\
\text { derivatives }\end{array}$ \\
\hline Diphenolic acid & $\begin{array}{c}\text { Meplacement for } \\
\text { Control of molecular weight \& properties } \\
\text { Control of polymerization processes } \\
\text { bisphenol A used in } \\
\text { polycarbonate } \\
\text { synthesis }\end{array}$ \\
\hline
\end{tabular}

Building block: Levulinic acid (LA)

- Family 1 - Reductions

- Family 2 - Oxidations

- Family 3 - Condensations

\subsubsection{Building Block Considerations}

LA is a product formed by treatment of 6-carbon sugar carbohydrates from starch or lignocellulosics with acid. Five carbon sugars derived from hemicelluloses (viz. xylose, arabinose) can also be converted to LA by addition of a reduction step subsequent to acid treatment. Thus, LA could serve as a valuable building block available from almost all sugars manufactured in the biorefinery. LA is one of the more recognized building blocks available from carbohydrates (and has attracted interest from a number of large chemical industry firms), and for that reason, has frequently been suggested as a starting material for a wide number of compounds. Figure 13 summarizes some possible derivatives of LA. 


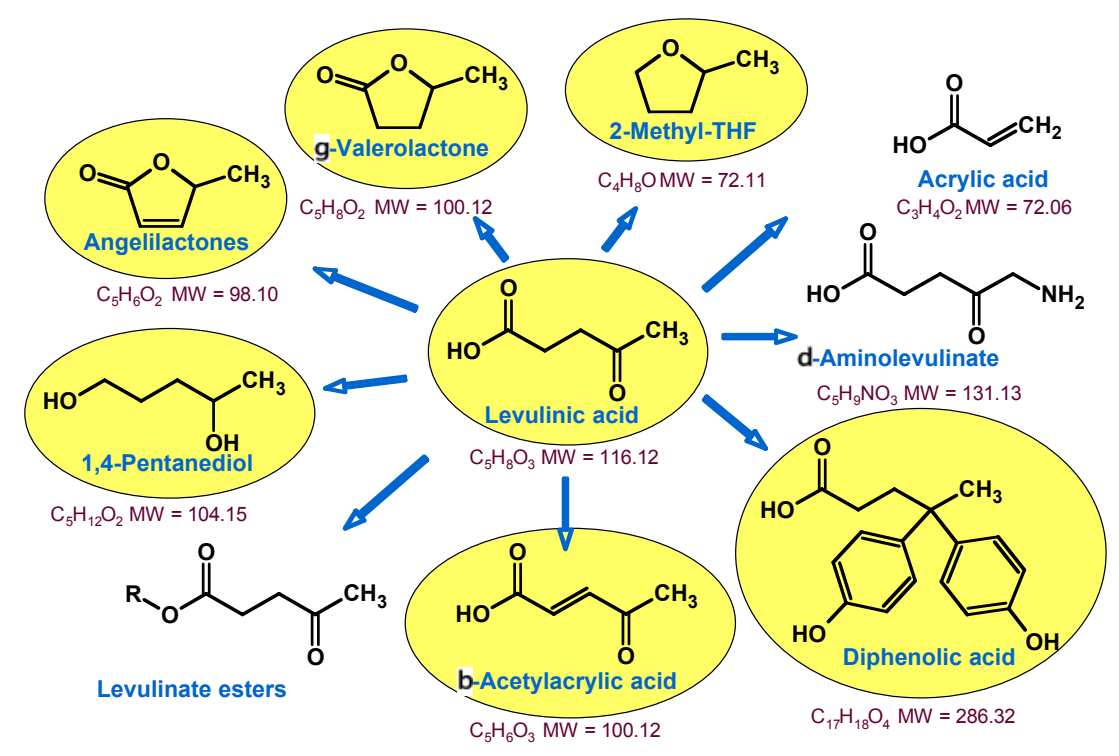

Figure 13-Derivatives of Levulinic Aid

\subsubsection{Derivative considerations}

The family of compounds available from LA is quite broad, and addresses a number of large volume chemical markets. Conversion of LA to methyltetrahydrofuran and various levulinate esters addresses fuel markets as gasoline and biodiesel additives, respectively. Deltaaminolevulinic acid is a herbicide, and targets a market of $200-300$ million $\mathrm{lb} / \mathrm{yr}$ at a projected cost of $\$ 2.00-3.00 / \mathrm{lb}$. An intermediate in the production of $\delta$-aminolevulinic acid is $\beta$-acetylacrylic acid. This material could be used in the production of new acrylate polymers, addressing a market of 2.3 billion $\mathrm{lb} / \mathrm{yr}$ with values of about $\$ 1.30 / \mathrm{lb}$. Diphenolic acid is of particular interest because it can serve as a replacement for bisphenol $\mathrm{A}$ in the production of polycarbonates. The polycarbonate resin market is almost 4 billion $\mathrm{lb} / \mathrm{yr}$, with product values of about $\$ 2.40 / \mathrm{lb}$. New technology also suggests that LA could be used for production of acrylic acid via oxidative processes. LA is also a potential starting material for production of succinic acid, whose applicability is described elsewhere in this report. Production of LAderived lactones offers the opportunity to enter a large solvent market, as these materials could be converted into analogs of $\mathrm{N}$-methylpyrrolidinone. Complete reduction of LA leads to 1,4-pentanediol, which could be used for production of new polyesters.

The technical barriers for this building block include improvement of the process for LA production itself. However, this conversion has been studied, and the LA yield is around $70 \%$. Determination of the value of increasing this yield through more selective dehydration processes would be useful, and an effort in developing new catalysts to facilitate this conversion could be of use. Greater impact could be realized by focusing effort on conversion of LA to various derivatives. Of particular interest are processes to facilitate selective oxidation of LA to succinic and acrylic acid, focusing on the use of simple oxidants such as oxygen or peroxide. Selective reduction of LA to the corresponding lactones and methyltetrahydrofuran will improve access to large volume fuel markets. Finally, development 
of diphenolic acid as a bisphenol A replacement, and investigation of the properties of the resulting polymers will provide a body of information to potential industrial partners interested in using the technology for the development of new products.

\subsubsection{Overall Outlook}

LA offers one of the larger families of potential industrial derivatives among the compounds included in the top 10 . Its low cost and ready availability from both 5-carbon and 6-carbon sugars suggests that it could be a building block of central importance within the biorefinery. R\&D will be necessary, especially to determine which of the many potential derivatives offer the best opportunities for partnering with industry. 


\section{$9.9 \quad 3-H y d r o x y b u t y r o l a c t o n e$}

\subsubsection{Pathways to Building Block From Sugars}

Table 35 - Pathways to Building Block from Sugars [Pathways to Building Block From Sugars - 3-Hydroxybutyrolactone]

\begin{tabular}{|c|c|c|}
\hline Type of pathway & Technical Barriers & $\begin{array}{c}\text { Direct Uses of } \\
\text { Butlling Block }\end{array}$ \\
\hline $\begin{array}{c}\text { Chemical- One step } \\
\text { Oxidative degradation } \\
\text { of starch (hydrogen } \\
\text { peroxide) }\end{array}$ & $\begin{array}{c}\text { Avoiding exotic oxidants in favor of air, } \\
\text { oxygen, dilute hydrogen peroxide. } \\
\text { Lowering concentrations of oxidants required } \\
\text { (safety issue) } \\
\text { Tolerance to inhibitory elements of biomass } \\
\text { based feedstocks } \\
\text { Ability to use wider range of lignocellulosics } \\
\text { for synthesis }\end{array}$ & $\begin{array}{c}\text { Intermediate for high } \\
\text { value pharma } \\
\text { compounds }\end{array}$ \\
\hline $\begin{array}{c}\text { Biotransformation- Not } \\
\text { likely }\end{array}$ & & \\
\hline
\end{tabular}

\subsubsection{Primary Transformation Pathway(s) to Derivatives}

Table 36 - Family 1: Reductions [Primary Transformation Pathway(s) to Derivatives - 3Hydroxybutyrolactone]

\begin{tabular}{|c|c|c|}
\hline $\begin{array}{c}\text { Derivative or } \\
\text { Derivative Family }\end{array}$ & $\begin{array}{c}\text { Technical barriers } \\
\text { pyrrolidones }\end{array}$ & $\begin{array}{c}\text { Potential use } \\
\text { of derivatives }\end{array}$ \\
\hline $\begin{array}{c}\text { Furans. Analogs of } \\
\text { Reduction at mild conditions - atmospheric } \\
\text { pressure, low T } \\
\text { helective reduction of aldehydes (RCHO) in } \\
\text { presence of alcohols (ROH) } \\
\text { Managing acid salts }\end{array}$ & Solvents \\
& $\begin{array}{c}\text { Selective reduction of specific functionalities, i.e. } \\
\text { Tolerance to inhibitory elements or components of } \\
\text { biomass based feedstocks (sugar streams) - } \\
\text { robust catalysts }\end{array}$ & \\
\hline
\end{tabular}


Table 37 - Family 2: Direct Polymerization [Pimary Transformation Pathway(s) to Derivatives - 3-Hydroxybutyrolactone]

\begin{tabular}{|c|c|c|}
\hline $\begin{array}{c}\text { Derivative or } \\
\text { Derivative Family }\end{array}$ & Technical barriers & $\begin{array}{l}\text { Potential use } \\
\text { of derivatives }\end{array}$ \\
\hline $\begin{array}{c}\text { Amino analogs to } \\
\text { tetrahydrofuran }\end{array}$ & $\begin{array}{c}\text { Manage rates } \\
\text { Selective esterifications to control branching } \\
\text { Control of molecular weight \& properties }\end{array}$ & $\begin{array}{c}\text { Amino analogs to } \\
\text { lycra fibers }\end{array}$ \\
\hline
\end{tabular}

Building Block: 3-Hydroxybutryolactone

- Family 1 - Reduction

- Family 2 - Direct Polymerization

\subsubsection{Building Block Considerations}

3-Hydroxybutyrolactone (3-HBL) is a cyclic C4 compound produced via chemical transformations. Production via fermentation routes is not likely. Chemical synthesis of this compound involves multiple steps and thus, is considered "messy" and/or difficult. One possible route to the building block starts with malic acid (2-hydroxysuccinic). Malic acid can be cyclized to form hydroxysuccinic anhydride, which, via reduction, gives the hydroxybutryolactone. Malic acid is currently produced from fumaric or maleic acid, both derived from maleic anhydride, which in turn is produced from vapor-phase oxidation of hydrocarbons (particularly butane). The conversion from fumaric to malic is done using fermentation. Thus, if biotechnology advances could lead to malic acid production from sugars, a more cost-effective pathway can be envisioned. Perhaps a direct bioconversion from sugar all the way to $3-\mathrm{HBL}$ may be possible as well. Thus, the major technical hurdles for the development of $3-\mathrm{HBL}$ as a building block include the development of lower cost fermentation routes.

\subsubsection{Derivative Considerations}

Ring opening reactions can produce hydroxy analogs of succinic acid as potential derivatives. Other potential derivatives include gamma-butenyl-lactone (via dehydration) and acrylate-lactone (via esterification). The chemistry of 3-HBL to the primary families of derivatives is shown in Figure 14. 


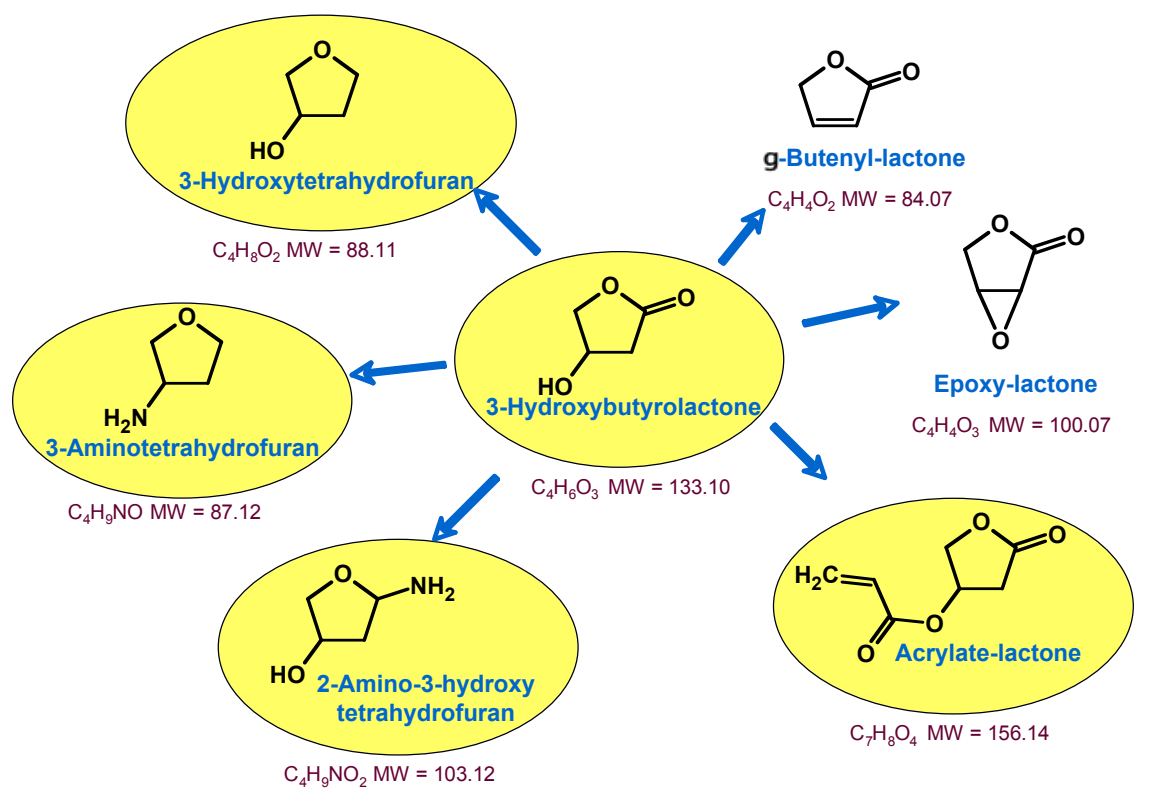

Figure 14 - 3-HBL Chemistry to Derivatives

Dehydration of 3-HBL can yield gamma-butenyl-lactone, and esterification can yield acrylatelactone. Potential uses for such derivatives may include new polymers. 3-HBL is currently used in pharmaceutical production.

\subsubsection{Overall Outlook}

The research and market opportunities for 3-hydroxybutyrolactone come from its potential to create new derivative compounds. Since it is produced as a specialty chemical for fairly high value uses, little attention has been paid to producing it as a commodity chemical intermediate and all the attendant issues with such development. This would be a challenging product to develop, but one that has some exciting opportunities. Engineering analyses to better define the metrics needed to achieve cost efficient production of this molecule would be required. 


\subsection{Glycerol}

\subsubsection{Pathways to Building Block}

Table 38 - Pathways to Building Block [Glycerol]

\begin{tabular}{|c|c|c|}
\hline Type of pathway & Technical Barriers & $\begin{array}{c}\text { Direct Uses of Bullding } \\
\text { Block }\end{array}$ \\
\hline $\begin{array}{c}\text { Transesterification of } \\
\text { oils }\end{array}$ & Few if any & $\begin{array}{c}\text { It is consumed in products } \\
\text { such as personal/oral care } \\
\text { products, drugs / } \\
\text { pharmaceuticals, } \\
\text { foods/beverages, and } \\
\text { polyether polyols (for } \\
\text { polyurethane). }\end{array}$ \\
\hline $\begin{array}{c}\text { Biotransformation - } \\
\text { Enzymatic } \\
\text { transesterification }\end{array}$ & $\begin{array}{c}\text { New, robust enzymes active in } \\
\text { methanol/water solutions, at costs } \\
\text { comparable to chemical esterification }\end{array}$ & Same \\
\hline
\end{tabular}

\subsubsection{Primary Transformation Pathway(s) to Derivatives}

Table 39 -Family 1: Oxidation [Primary Transformation Pathway(s) to Derivatives [Glycerol]

\begin{tabular}{|c|c|c|}
\hline $\begin{array}{c}\text { Derivative or } \\
\text { Derivative Family }\end{array}$ & Technical barriers & $\begin{array}{l}\text { Potential use of } \\
\text { derivatives }\end{array}$ \\
\hline $\begin{array}{c}\text { PLA Analogs, Glyceric } \\
\text { Acid }\end{array}$ & $\begin{array}{c}\text { Alcohols }(\mathrm{ROH}) \text { to acids }(\mathrm{RCOOH}) \\
\text { Avoiding exotic oxidants in favor of air, } \\
\text { oxygen, hydrogen peroxide } \\
\text { Tolerance to inhibitory components of } \\
\text { biomass processing streams } \\
\text { Oxidation of aldehydes to acids and alcohols } \\
\text { to aldehydes }\end{array}$ & $\begin{array}{c}\text { PLA with better } \\
\text { polymeric properties } \\
\text { Polyester fibers with } \\
\text { new properties }\end{array}$ \\
\hline
\end{tabular}

Table 40 - Family 2: Bond Breaking (Hydrogenolysis) [Primary Transformation Pathway(s) to Derivatives [Glycerol]

\begin{tabular}{|c|c|c|}
\hline $\begin{array}{c}\text { Derivative or } \\
\text { Derivative Family }\end{array}$ & $\begin{array}{c}\text { Technical barriers } \\
\text { Propylene glycol }\end{array}$ & $\begin{array}{l}\text { Potential use of } \\
\text { derivatives }\end{array}$ \\
\hline $\begin{array}{c}\text { Specificity for C-C \& C-O bonds } \\
\text { Increasing rates }\end{array}$ & $\begin{array}{c}\text { Antifreeze, humectant, } \\
\text { etc. }\end{array}$ \\
\hline 1,3-propanediol & Same as above & Sorona fiber \\
\hline
\end{tabular}


Family 3: Direct Polymerization

Table 41 - Family 3: Direct Polymerization [Primary Transformation Pathway(s) to Derivatives [Glycerol]

\begin{tabular}{|c|c|c|}
\hline $\begin{array}{c}\text { Derivative or } \\
\text { Derivative Family }\end{array}$ & Technical barriers & $\begin{array}{l}\text { Potential use of } \\
\text { derivatives }\end{array}$ \\
\hline $\begin{array}{c}\text { Branched polyesters } \\
\text { and polyols }\end{array}$ & $\begin{array}{c}\text { Manage rates } \\
\text { Selective esterifications to control } \\
\text { branching } \\
\text { Control of molecular weight \& } \\
\text { properties }\end{array}$ & $\begin{array}{c}\text { Unsaturated Polyurethane } \\
\text { Resins for use in insulation }\end{array}$ \\
\hline
\end{tabular}

Building block: Glycerol

- Family 1: Oxidation

- Family 2: Bond breaking (hydrogenolysis)

- Family 3: Direct polymerization

\subsubsection{Building Block Considerations}

Glycerol holds the potential of being an extremely versatile building block within the biorefinery. Glycerol is currently a well-recognized item of commerce with an annual world production of $500-750 \times 10^{3}$ tonnes. In 1945, the work of Leffingwell described over 1500 different uses for glycerol. ${ }^{2}$ The United States is one of the world's largest suppliers and consumers of refined glycerol. Glycerol and various simple derivatives of glycerol (such as glycerol triacetate, glycerol stearate, and glycerol oleate) are currently produced by the chemical industry at companies such as Uniqema, Procter and Gamble, and Stepan. ${ }^{3}$ Glycerol is produced in two forms: natural glycerol, as a byproduct of the oleochemical and biodiesel industries, and synthetic glycerol, from propylene. Approximately $75 \%$ of the U.S. supply of glycerol is derived from natural sources, and the remaining $25 \%$ is produced synthetically. Nearly all crude glycerol is refined before its ultimate end use.

Although many uses have been developed for glycerol, most product markets are currently small and fragmented, reflecting glycerol's relatively high price of $\$ 0.60-0.90 / \mathrm{lb}$. However, development of a biodiesel market could have a huge impact on the availability and use of glycerol. Since glycerol is a key coproduct of biodiesel manufacture, increasing use of biodiesel will lead to much greater glycerol availability and lower cost. The lowest price that crude glycerol could fall to is $\$ 0.05 / \mathrm{lb}$, because at that value steam reforming to hydrogen, animal feed, and other values will create large markets for crude glycerol. Glycerol prices could fall to $\$ 0.20 / \mathrm{lb}$ which is the industry average cost for refining glycerol today although crude, unrefined glycerol, glycerin, may be available for a lower cost ${ }^{3}$. If prices drop into the $\$ 0.20$ - $\$ 0.50 / \mathrm{lb}$ range, glycerol can become a major building block for the biorefinery. Small increases in fatty acid consumption for fuels and products can increase world glycerol production significantly. If the United States displaced $2 \%$ of the on-road diesel with biodiesel by 2012, almost 800 million pounds of new glycerol supplies would be produced. ${ }^{4}$ Figure 15 describes how glycerol could be used as a building block for the production of a family of derivatives.

\footnotetext{
2 Leffingwell, G.; Lesser, M. Merck Index, $11^{\text {th }}$ edition, p. 705 (1945)

3 Glycerol refining costs for industry provided by Proctor \& Gamble, July 17, 2003

4. Tyson, K. Shaine, Oil Platform Analysis: A Scoping Study for Biorefineries, NREL Technical Report (2004), in press.
} 


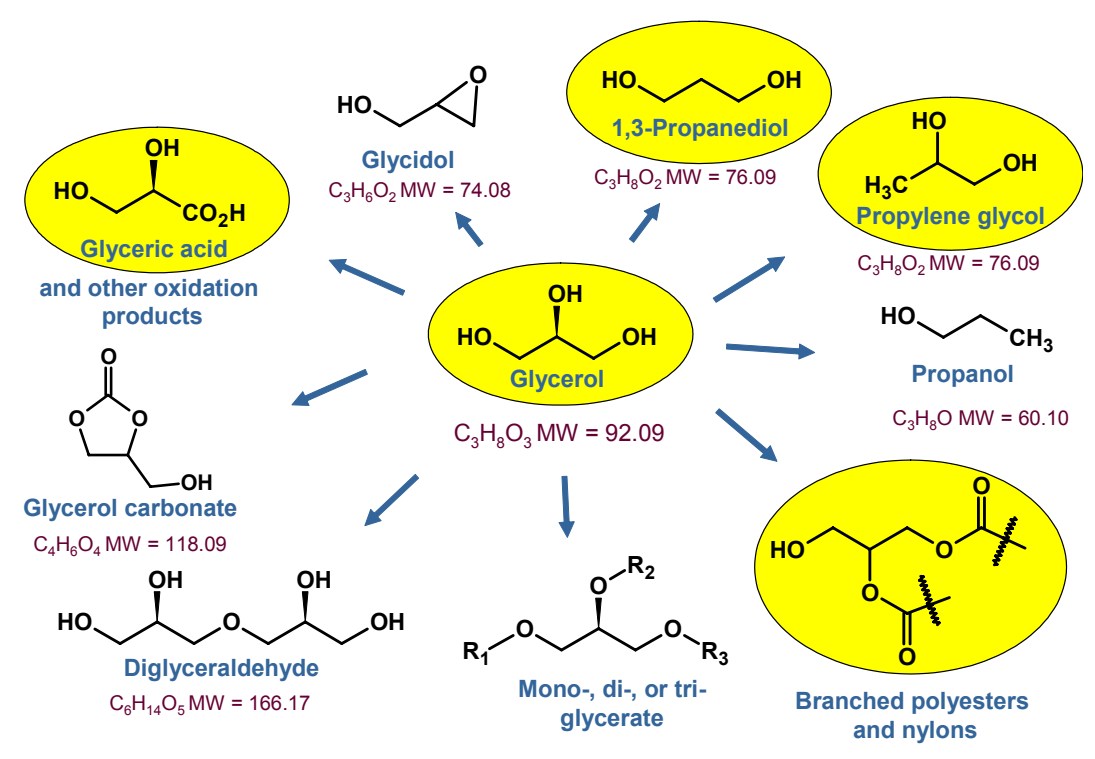

Figure 15 - Derivatives of Glycerol

\subsubsection{Derivative Considerations}

Historically, the cost of glycerol has meant that it was either used directly, or subjected to very simple structural modifications. Current derivatives include glycerol triacetate, glycerol esters (stearate, oleate), produced through chemical catalysis. At lower projected costs, there is a tremendous potential to develop a variety of new processes and product lines from glycerol, taking advantage of its unique structure and properties. As glycerol is a nontoxic, edible, biodegradable compound, it will provide important environmental benefits to the new platform products. Lower cost glycerol could open significant markets in polymers, ethers, and other compounds. From a technical standpoint, glycerol's multifunctional structure can be exploited by several different means, as shown by the potential glycerol product family in Figure 16. It is important to note that technology developed for glycerol would have broad crosscutting applications throughout the biorefinery. Since glycerol is structurally analogous to sugars, conversion processes developed for glycerol would also be applicable to inexpensive glucose, xylose, etc., greatly increasing the diversity of the biorefinery.

Selective oxidation of glycerol leads to a very broad family of derivatives that would serve as new chemical intermediates, or as components of new branched polyesters or nylons. These products would address very large chemical markets. Targeted polyesters have markets of 2-3 billion $\mathrm{lb} / \mathrm{yr}$, at values between $\$ 1.00-3.50 / \mathrm{lb}$, while nylons are a 9 billion $\mathrm{lb} / \mathrm{yr}$ market with values between $\$ 0.85-2.20 / \mathrm{lb}$, depending on use. Technical barriers for production of these materials include the need to develop selective catalytic oxidation technology that can operate on a polyfunctional molecule such as glycerol. The processes will also need to use simple oxidants, such as oxygen or air, to carry out the required transformations.

New bond breaking (hydrogenolysis) technology will lead to the formation of a number of valuable intermediates. Propylene glycol (PG) and 1,3-propanediol (PDO) are promising potential derivatives that could be produced from glycerol by development of appropriate catalytic systems. PDO can be produced through aerobic fermentation, however, a direct 
route from glucose to PDO (Dupont) is likely to be more cost effective. The conversion to PG would be via chemical catalysis. With the capacity to produce 1.5 billion Ib/yr of PG in the US, PG offers a huge potential market for glycerol. A key barrier for this transformation is to make it cost competitive with the current petroleum route. Again, an important technical barrier is the need to develop selective catalysts to carry out these transformations, specifically, catalysts that can differentiate between $\mathrm{C}-\mathrm{C}$ and $\mathrm{C}-\mathrm{O}$ bonds.

\subsubsection{Overall Outlook}

Glycerol offers a very large number of opportunities for chemical production, and with the expected drop in cost, could become one of the more important building blocks for the biorefinery. Given its potential, a preliminary economic screening of the glycerol potential has been carried out as part of the evaluation for the oils platform. This information is shown in Table 42. This evaluation could help to screen some of the many possibilities for glycerol. 
Table 42- Preliminary Economic Screening of the Glycerol Potential ${ }^{5}$

\begin{tabular}{|c|c|c|c|c|c|c|}
\hline Product & Current market size (lb) & $\begin{array}{l}\text { Estimated raw } \\
\text { material cost } \\
\text { from glycerol } \\
(\$ / l b)\end{array}$ & $\begin{array}{l}\text { Estimated raw material } \\
\text { cost for commercial } \\
\text { material }(\$ / l b)\end{array}$ & $\begin{array}{l}\text { Comparative commercial } \\
\text { product cost }(\$ / l b)\end{array}$ & $\begin{array}{c}\text { CEH } \\
\text { Source }\end{array}$ & Opportunity \\
\hline \multicolumn{7}{|l|}{ New polyesters } \\
\hline $\begin{array}{c}\text { Thermoplastic engineering } \\
\text { polyesters }\end{array}$ & $924 \times 10^{6}(\mathrm{PBT}) ; 152 \times 10^{6}(\mathrm{PET})$ & $0.29-0.34$ & $\begin{array}{c}0.379 \text { (PET) } \\
0.59 \text { (PBT) }\end{array}$ & $1.00-1.40(2002)$ & 695.4020 & +++++ \\
\hline Polyester film & $2209 \times 10^{6}$ & $0.29-0.34$ & 0.379 (PET) & $1.05-3.50(2001)$ & 580.1170 & +++++ \\
\hline Polyester polyols & $1276 \times 10^{6}$ & $0.29-0.34$ & $\begin{array}{l}0.88 \text { (aliphatic) } \\
0.34 \text { (aromatic) }\end{array}$ & $\begin{array}{c}0.65-0.70 \text { (foams) } \\
0.35-0.55 \text { (aromatic } \\
\text { foams) } \\
1.10-1.30 \text { (nonfoam) } \\
{[2001]}\end{array}$ & 688.2000 & +++ \\
\hline Polyester fibers & $35864 \times 10^{6}$ & $0.29-0.34$ & 0.37 (PET) & $\begin{array}{c}0.63(1999) \\
0.90-1.02(1996)\end{array}$ & 541.9000 & ++ \\
\hline $\begin{array}{c}\text { Unsaturated polyester } \\
\text { resins }\end{array}$ & $3896 \times 10^{6}$ & $\begin{array}{l}\text { Formulation } \\
\text { R\&D needed }\end{array}$ & & $0.55-1.50(2001)$ & 580.1200 & +++ \\
\hline COPE elastomers & $152 \times 10^{6}(2000)$ & $1.20-1.62$ & $1.35-1.75$ & $3.15-3.62$ & 525.8200 & ++++ \\
\hline $\begin{array}{l}\text { Polyurethane foams } \\
\text { Polyurethane elastomers } \\
\text { Alkyd resins and coatings }\end{array}$ & $\begin{array}{l}8661 \times 10^{6} \\
1276 \times 10^{6}\end{array}$ & $\begin{array}{l}0.29-0.34 \\
0.29-0.34\end{array}$ & 1.06 & $\begin{array}{l}0.22-0.33 \\
1.85-4.72\end{array}$ & $\begin{array}{l}580.1600 \\
525.6600\end{array}$ & $\begin{array}{c}+ \\
++++\end{array}$ \\
\hline Resins & $1575 \times 10^{6}(2000)$ & 0.35 & 0.53 & $0.75-1.35$ & 592.6000 & ++++ \\
\hline Coatings & $4108 \times 10^{6}(2000)$ & 0.35 & 0.53 & $1.22-2.60$ & 592.6000 & +++++ \\
\hline $\begin{array}{l}\text { Glycerol oxidation } \\
\text { products }\end{array}$ & $\begin{array}{l}\text { New market; projected initial uses } \\
\text { in polymer markets above, and as } \\
\text { chemical intermediates }\end{array}$ & $0.30-0.45$ & & & & +++++ \\
\hline
\end{tabular}

$55^{5}$ Leffingwell, G.; Lesser, M. Merck Index, 11 th edition, p. 705 (1945).

${ }^{5}$ Uniqema - http://www.uniqema.com/tech/index.htm

Stepan - http://www.stepan.com/aboutstepan/about.asp

Procter and Gamble - http://www.pg.com/frameset fs.jhtml?frameURL=http $\% 3 \mathrm{~A} / /$ www.pgchemicals.com 
Table 43- Preliminary Economic Screening of the Glycerol Potential (Continued)

\begin{tabular}{|c|c|c|c|c|c|c|}
\hline Product & Current market size (lb) & $\begin{array}{l}\text { Estimated raw } \\
\text { material cost } \\
\text { from glycerol } \\
(\$ / l b)\end{array}$ & $\begin{array}{c}\text { Estimated raw material } \\
\text { cost for commercial } \\
\text { material }(\$ / l b)\end{array}$ & $\begin{array}{c}\text { Comparative commercial } \\
\text { product cost }(\$ / l b)\end{array}$ & $\begin{array}{c}\text { CEH } \\
\text { Source }\end{array}$ & Opportunity \\
\hline New nylons & $9028 \times 10^{6}$ & $0.73-0.87$ & $0.96-1.02$ & $\begin{array}{l}1.25-1.70 \text { (carpet) } \\
2.15-2.20 \text { (textile) } \\
0.85-0.12 \text { (staple) }\end{array}$ & 541.7000 & ++++ \\
\hline $\begin{array}{l}\text { PLA analogs } \\
\text { Surfactants }\end{array}$ & $\begin{array}{c}308 \times 10^{6} \text { for PLA } \\
10721 \times 10^{6}\end{array}$ & $\begin{array}{l}0.36-0.51 \\
\text { Formulation } \\
\text { R\&D needed }\end{array}$ & New products & $\begin{array}{l}0.75-1.00 \text { for PLA } \\
\text { Wide range of costs }\end{array}$ & $\begin{array}{l}670.5000 \\
583.8000\end{array}$ & $\begin{array}{l}++++ \\
+++?\end{array}$ \\
\hline $\begin{array}{c}\text { Acrylic acid } \\
\text { Glycerol carbonate }\end{array}$ & $\begin{array}{c}7596 \times 10^{6} \\
\text { Unknown; propylene carbonate is } \\
\text { about } 21 \times 10^{6} \mathrm{lb} / \mathrm{yr}\end{array}$ & $\begin{array}{l}0.26-0.44 \\
0.20-0.35\end{array}$ & $\begin{array}{c}\sim 0.12 \\
0.84-0.91 \text { for dimethyl } \\
\text { carbonate }\end{array}$ & $\begin{array}{c}0.87 \\
0.50-0.60 \text { for dimethyl } \\
\text { carbonate from India }\end{array}$ & 606.4000 & $\begin{array}{c}++ \\
++++\end{array}$ \\
\hline
\end{tabular}

Key: $+++++=$ good $;++++=$ intermediate to good $;+++=$ intermediate $;++=$ poor to intermediate; $+=$ poor 


\subsection{Sorbitol (Alcohol Sugar of Glucose)}

9.11.1 Pathways to Building Block

Table 44 -Pathways to Building Block [Sorbitol]

\begin{tabular}{|c|c|c|}
\hline Type of pathway & Technical Barriers & $\begin{array}{c}\text { Direct Uses of } \\
\text { Bullding Block }\end{array}$ \\
\hline $\begin{array}{c}\text { Chemical - Hydrogenation of } \\
\text { glucose }\end{array}$ & $\begin{array}{c}99.7 \% \text { yield, few if any technical } \\
\text { barriers }\end{array}$ & \\
\hline Biotransformation - None & & \\
\hline
\end{tabular}

9.11.2 Primary Transformation Pathway(s) to Derivatives

Table 45 - Family 1: Dehydration [Primary Transformation Pathway(s) to Derivatives Sorbitol]

\begin{tabular}{|c|c|c|}
\hline $\begin{array}{l}\text { Derivative or Derivative } \\
\text { Family }\end{array}$ & Technical barriers & $\begin{array}{c}\text { Potential use of } \\
\text { derivatives }\end{array}$ \\
\hline Isosorbide, anhydrosugars & $\begin{array}{c}\text { Selective dehydrations without side } \\
\text { reactions }\end{array}$ & $\begin{array}{c}\text { PET like polymers such } \\
\text { as Polyethylene } \\
\text { isosorbide } \\
\text { terephthalates (bottles, in } \\
\text { use for hot-fill) } \\
\text { lactones }\end{array}$ \\
& $\begin{array}{c}\text { New heterogeneous catalyst } \\
\text { systems (solid acid catalyst) to } \\
\text { replace liquid catalyst systems }\end{array}$ & \\
\hline
\end{tabular}

Table 46 - Family 2: Bond Cleavage (hydrogenolysis) [Primary Transformation Pathway(s) to Derivatives - Sorbitol]

\begin{tabular}{|c|c|c|}
\hline $\begin{array}{l}\text { Derivative or Derivative } \\
\text { Family }\end{array}$ & $\begin{array}{c}\text { Technical barriers } \\
\text { Propylene glycol, lactic acid }\end{array}$ & $\begin{array}{c}\text { Specificity for C-C \& C-O bonds } \\
\text { Increasing rates } \\
\text { Tolerance to catalyst poisons } \\
\text { (biomass sugar streams) }\end{array}$ \\
\hline
\end{tabular}


Table 47 - Family 3: Direct Polymerization [Primary Transformation Pathway(s) to Derivatives - Sorbitol]

\begin{tabular}{|c|c|c|}
\hline $\begin{array}{l}\text { Derivative or Derivative } \\
\text { Family }\end{array}$ & Technical barriers & $\begin{array}{l}\text { Potential use of } \\
\text { derivatives }\end{array}$ \\
\hline Branched polysaccharides & $\begin{array}{c}\text { Selective esterifications to control } \\
\text { branching } \\
\text { Control of molecular weight \& } \\
\text { properties }\end{array}$ & $\begin{array}{c}\text { Water soluble polymers } \\
\text { (water treatment,etc), } \\
\text { new polymer } \\
\text { applications }\end{array}$ \\
\hline
\end{tabular}

Building Block: Sorbitol

Primary Derivatives:

- Family 1: Dehydration

- Family 2: Bond cleavage (hydrogenolysis)

- Family 3: Direct Polymerization

Sorbitol is the hydrogenation product of glucose. The production of sorbitol is practiced commercially by several companies and has a current production volume on the order of 200 million pounds annually. All of the commercial processes are based on batch technology and the use of Raney nickel as the catalyst. The major reason for using batch technology is to ensure complete conversion of the glucose. This is an important requirement because the majority of the applications for sorbitol are in the food industry and there are very strict requirements for the amount of reducing sugars in the sorbitol product.

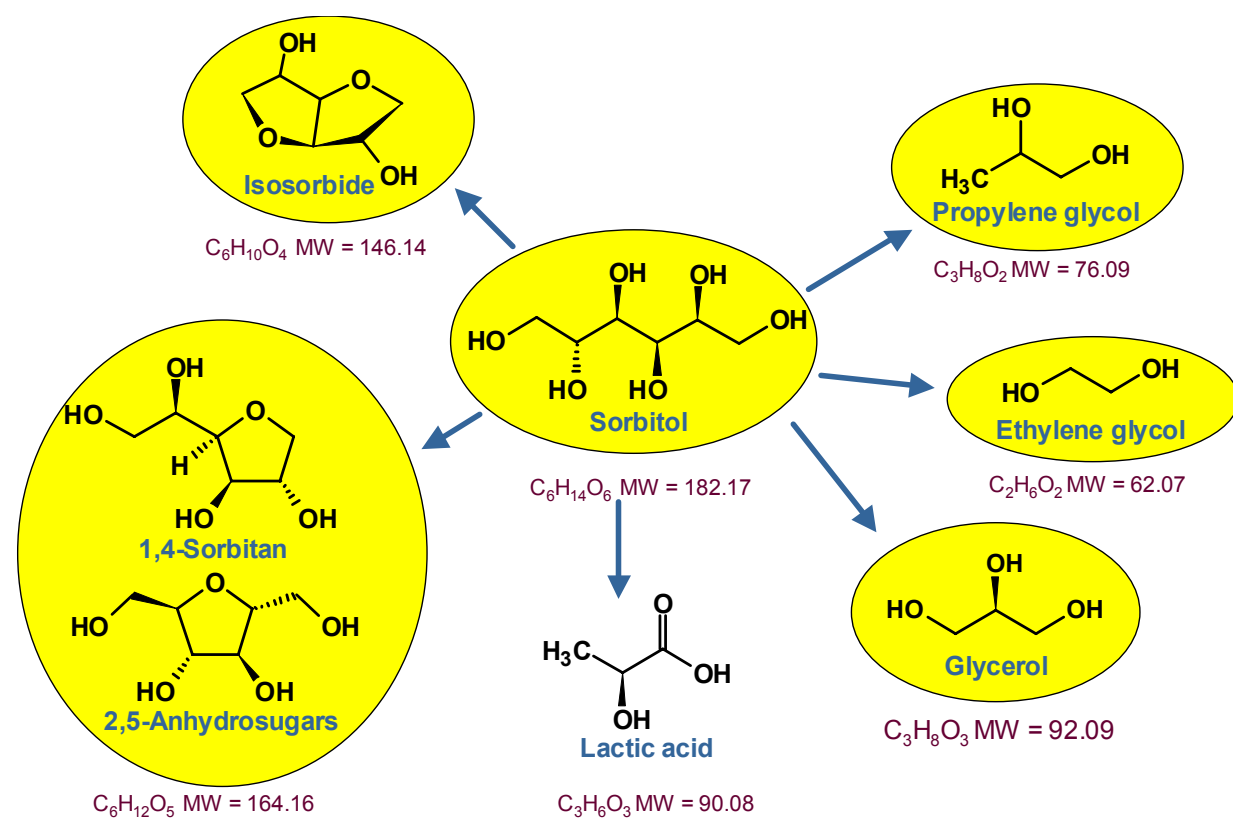

Figure 16 - Sorbitol Chemistry to Derivatives

The use of sorbitol as a building block for derivatives essentially requires no technical development. The only change would be the conversion of glucose to sorbitol in a 
continuous process instead of a batch process. Engelhard has demonstrated that the continuous production of sorbitol from glucose can be done continuously using a ruthenium on carbon catalyst. The yields demonstrated were near 99 percent with very high weight hourly space velocity. This would make sorbitol a very inexpensive feedstock for producing derivatives.

Inexpensive sorbitol affords the potential for the production of isosorbide at low costs. Isosorbide has been demonstrated to be a very effective monomer for raising the glass transition temperature of polymers. The major applications are as a copolymer with PET for the use in bottle production. These applications include ridged bottles as well as the ability to use plastic to replace glass in hot fill applications.

\subsubsection{Building Block Considerations}

As was described above there are virtually no building block considerations for sorbitol with the exception of the actual demonstration of a continuous process. Because the hydrogenation of glucose to sorbitol is so straight forward, it is not anticipated that there would be any difficulties in the scale up.

\subsubsection{Derivative Considerations}

\section{Family 1: Isosorbide}

The challenge in producing isosorbide from sorbitol is the development of process conditions and dehydration catalysts that afford high yield of isosorbide. The best reported yields are around $76 \%$. In order to increase the use of isosorbide, increased yields to $90 \%$ would be desirable. This not only reduces the production cost but also reduces the recovery and purification costs.

\section{Family 2: Glycols}

The conversion of sorbitol to glycols, namely propylene glycol is based on the hydrogenolysis of sorbitol. The major difficulty is producing propylene glycol in high yields. The best results in the literature show only about 35 pounds of PG from 100 pounds of sorbitol. In order to be commercially viable, this yield needs to be near 60 pounds per 100 pounds of sorbitol. New catalyst systems that afford high yield of PG are needed for commercial success.

\section{Family 3: Direct polymerization}

Copolymerization with other glycols in the unsaturated polyester resin market would be a major opportunity. Other direct polymerizations would yield polyesters that would need to be evaluated for properties and compared with other polyesters.

\subsubsection{Overall Outlook}

Sorbitol has the potential to be an outstanding building block for commodity chemicals. The conversion of sorbitol to isosorbide affords the opportunity for a high value monomer intermediate for several commercial applications. The conversion of sorbitol to glycols affords the opportunity to utilize a renewable resource for the production of a large-scale commodity chemical. 


\subsection{Xylitol/arabinitol (Sugar alcohols from xylose and arabinose)}

\subsubsection{Pathways to Building Block From Sugars}

Table 48 - Pathways to Building Block From Sugars [ Xylitol/arabinitol]

\begin{tabular}{|c|c|c|}
\hline Type of pathway & Technical Barriers & $\begin{array}{c}\text { Direct Uses of } \\
\text { Bullding Block }\end{array}$ \\
\hline $\begin{array}{c}\text { Chemical- Hydrogenation of } \\
\text { sugars or extraction from } \\
\text { biomass pretreatment } \\
\text { processes. }\end{array}$ & $\begin{array}{c}\text { Very few if any. Commercial } \\
\text { processes }\end{array}$ & $\begin{array}{c}\text { Non-nutritive } \\
\text { sweeteners, } \\
\text { anhydrosugars, } \\
\text { unsaturated polyester } \\
\text { resins (UPRs) }\end{array}$ \\
\hline $\begin{array}{c}\text { Biotransformation- Result of } \\
\text { pretreatment stream for } \\
\text { lignocellulosic processing }\end{array}$ & Separation from other sugars & \\
\hline
\end{tabular}

\subsubsection{Primary Transformation Pathway(s) to Derivatives}

Table 49 - Family 1: Oxidations [Primary Transformation Pathway(s) to Derivatives Xylitol/arabinitol]

\begin{tabular}{|c|c|c|}
\hline $\begin{array}{l}\text { Derivative or Derivative } \\
\text { Family }\end{array}$ & Technical barriers & $\begin{array}{l}\text { Potential use of } \\
\text { derivatives }\end{array}$ \\
\hline $\begin{array}{c}\text { Xylaric and Xylonic acids } \\
\text { Arabonic acid and Arabinoic } \\
\text { acid } \\
\text { Xylaric and Xylonic acids } \\
\text { Arabonic acid and Arabinoic } \\
\text { acid }\end{array}$ & $\begin{array}{c}\text { Selective oxidation of alcohols (ROH) } \\
\text { to acids (RCOOH) } \\
\text { Avoiding exotic oxidants in favor of air, } \\
\text { oxygen, dilute hydrogen peroxide. } \\
\text { Lowering concentrations of oxidants } \\
\text { required (safety issue) } \\
\text { Tolerance to inhibitory elements of } \\
\text { biomass based feedstocks (sugar } \\
\text { streams) } \\
\text { Facile and selective conversion of } \\
\text { aldehydes to acids and alcohols to } \\
\text { aldehydes } \\
\text { Enzymatic oxidation requires } \\
\text { cofactors }\end{array}$ & New uses \\
\hline
\end{tabular}


Table 50 - Family 2: Bond Cleavage (hydrogenolysis) [Primary Transformation Pathway(s) to Derivatives - Xylitol/arabinitol]

\begin{tabular}{|c|c|c|}
\hline $\begin{array}{c}\text { Derivative or Derivative } \\
\text { Family }\end{array}$ & Technical barriers & $\begin{array}{l}\text { Potential use of } \\
\text { derivatives }\end{array}$ \\
\hline $\begin{array}{c}\text { Polyols (propylene and } \\
\text { ethylene glycols) } \\
\text { Lactic acid }\end{array}$ & $\begin{array}{c}\text { Specificity among C-O and C-C bonds } \\
\text { Increasing rates } \\
\text { Tolerance to catalyst poisons } \\
\text { (biomass processing streams and } \\
\text { purity) }\end{array}$ & Antifreeze, UPRs, \\
\hline
\end{tabular}

Table 51 - Family 2: Direct Polymerization [Primary Transformation Pathway(s) to Derivatives - Xylitol/arabinitol]

\begin{tabular}{|c|c|c|}
\hline $\begin{array}{c}\text { Derivative or Derivative } \\
\text { Family }\end{array}$ & Technical barriers & $\begin{array}{l}\text { Potential use of } \\
\text { derivatives }\end{array}$ \\
\hline $\begin{array}{c}\text { Xylitol, xylaric, xlyonic } \\
\text { polyesters and nylons } \\
\text { Same sequence for arabinitol }\end{array}$ & $\begin{array}{c}\text { Manage rates } \\
\text { Selective esterifications to control } \\
\text { branching } \\
\text { Control of molecular weight \& } \\
\text { properties }\end{array}$ & $\begin{array}{c}\text { Newportunities } \\
\text { oppor }\end{array}$ \\
\hline
\end{tabular}

Building Block: Xylitol/Arabinitol

Primary Derivatives:

Family 1: Oxidation

Family 2: Bond cleavage (Hydrogenolysis)

Family 3: Direct polymerization

Xylitol and arabinitol are hydrogenation products from the corresponding sugars xylose and arabinose. There is limited commercial production of xylitol and no commercial production of arabinitol. Xylitol is used as a non-nutritive sweetener. The technology required to convert the five carbon sugars xylose and arabinose to xylitol and arabinitol can be modeled based on the conversion of glucose to sorbitol. The hydrogenation of the five carbon sugars to the sugar alcohols occurs with one of many active hydrogenation catalysts such as nickel, ruthenium and rhodium. There is no major technical barrier associated with the production of the five-carbon sugar alcohols xylitol and arabinitol.

The production of xylitol for use as a building block for derivatives essentially requires no technical development. Based on the related chemistry of sorbitol production from glucose it is expected that the conversion of xylose to xylitol would be expected in the $99 \%$ yield range. Engelhard has demonstrated that the continuous production of sorbitol from glucose can be done continuously using a ruthenium on carbon catalyst. The yields demonstrated were near 99 percent with very high weight hourly space velocity and should be consistent for xylitol production. If the xylose feedstock is inexpensive then the production of xylitol could be done for very low cost. 


\subsubsection{Building Block Considerations}

As was described above there are virtually no building block considerations for xylitol with the exception of the actual demonstration of a continuous process. Because the hydrogenation of glucose to sorbitol is so straight forward, it is not anticipated that there would be any difficulties for the production of xylitol from xylose and the only need would be in the demonstration of scale up.

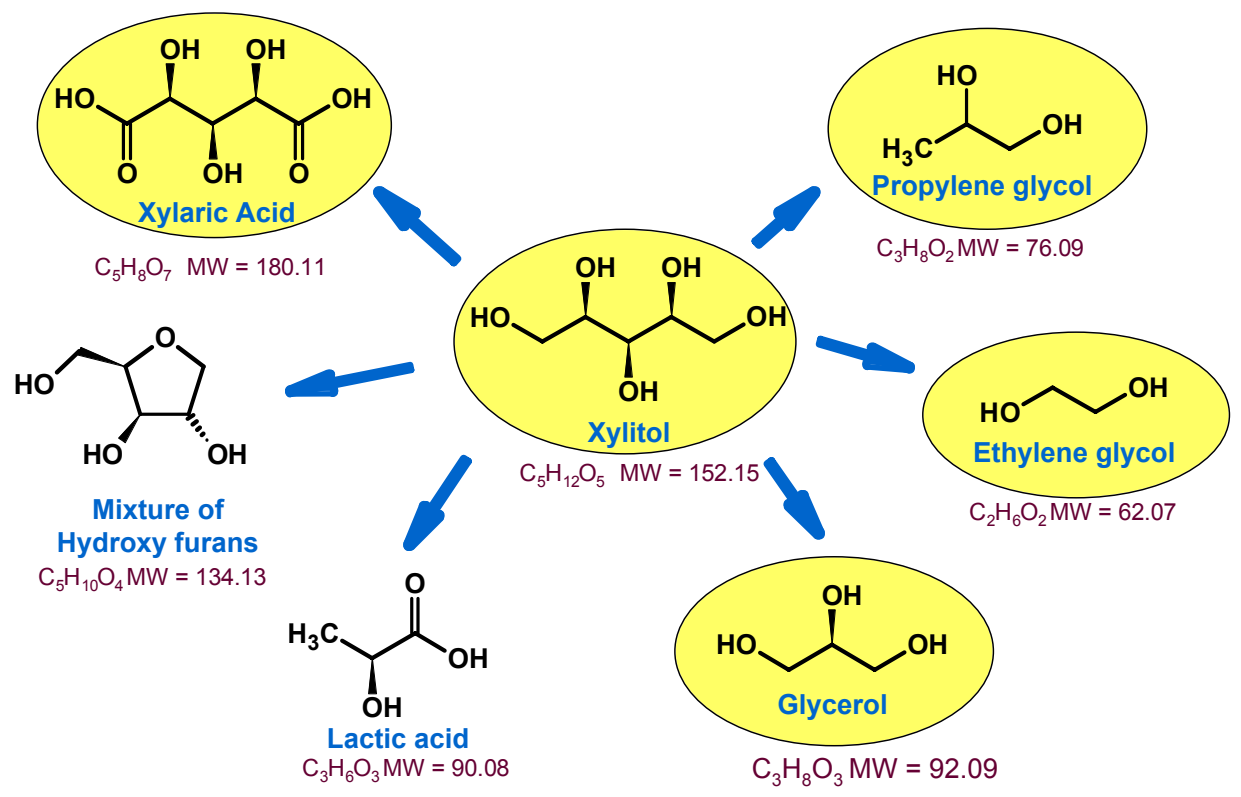

Figure 17 - Chemistry to Derivatives of Xylitol and Arabinitol

\subsubsection{Derivative Considerations}

\section{Family 1: Xylaric Acid}

Xylaric acid requires the selective oxidation of xylitol. The oxidation chemistry has been demonstrated for the oxidation of sorbitol to glucaric acid but with low efficiency. Yields for this reaction are reported at about $60 \%$, which is not a showstopper but the separation of glucaric acid from the product mixture is problematic. New catalysts need to be developed that afford high yields of xylaric acid. In addition, it will be essential to develop the process in a manner that affords the use of oxygen as the oxidizing agent instead of oxidants like nitric acid, or peracetic acid. It is anticipated that the overall yields will need to be $90 \%$ or greater for an economic process to be consider for commercial deployment.

\section{Family 2: Glycols}

The conversion of xylitol to glycols, namely propylene glycol and ethylene glycol is based on hydrogenolysis. It has been demonstrated that reasonably good yields (80\%) of ethylene glycol and propylene glycol can be achieved from xylitol. Improvement in the yields to greater than $90 \%$ would further improve the economics. The current challenge is finding a 
low cost xylose sugar stream. One interesting concept may be to develop a process from mixed sugars that include xylose, arabinose and glucose for the conversion to propylene glycol as the primary product and ethylene glycol as the secondary product. This scenario could potentially afford a low cost route to glycols. The economics of this need to be demonstrated by some additional detailed modeling.

\section{Family 3: Direct polymerization}

Copolymerization with other glycols for the unsaturated polyester resin market would be one of the major opportunities. Other direct polymerizations would yield polyesters that would need to be evaluated for properties and compared with other polyesters. However, polymers with five carbon subunits possibly provide properties that are different from even numbered polymers.

\subsubsection{Overall Outlook}

C5 sugars such as xylose and arabinose have the potential to be an outstanding building block for commodity chemicals. One challenge will be getting a relatively clean feed stream of these sugars. The conversion of these sugars to the sugar alcohol and subsequent conversion to glycols has been demonstrated and could be a first generation process for the production of propylene glycol and ethylene glycol. 


\section{Catalog of Potential Chemicals and Materials from Biomass}

As described above, the report started with a group of over 300 potential compounds that could be made from biomass. The final version of this report will contain a URL for a searchable database of these compounds. 


\section{Bibliography}

\section{References Used to Develop Catalog for Potential Biobased Products}

Aggressive Growth in the Use of Bio-derived Energy and Products in the United States by 2010. Final Report and Data Volume, Arthur D. Little, October, 2001.

Alternative Feedstocks Program Technical and Economic Assessment: Thermal/Chemical and Bioprocessing Components. Prepared for DOE's Office of Industrial Technologies, J. Bozell and R. Landucci, Editors, NREL 1993.

Biobased Products. Prepared for the Fifth Biomass Conference of the Americas by M. Paster and T. Carole. September, 2001 (personal communication).

Chemical Economics Handbook, Stanford Research Institute International, Palo Alto, CA, 2002

Industrial Bioprocessing Alert. An electronic newsletter published regularly by Technical Insights Alert. Copyright 2003, Frost \& Sullivan, San Antonio, TX 78229. ISSN 1056-7194.

Industrial Utilization of Renewable Resources: An Introduction. H.J. Szmant. Technomic Publishing Company, Inc., Lancaster, Pennsylvania, 1986.

Process Economics Program Yearbook, 2002, Volume 3E. SRI Consulting, Menlo Park, California (contains process economics for 934 routes to produce 534 chemicals in the United States, Germany and Japan).

Production of Organic Chemicals via Bioconversion: A Review of the Potential. Prepared for the US DOE's Idaho Operations Office. S. A. Leeper, T.E. Ward, and G. F Andrews. EGG2645, July 1991.

The Bioproducts Industry: Today and Tomorrow. Prepared for DOE's Office of the Biomass Program by Energetics, Incorporated. M. Paster, J. Pellegrino and T. Carole. July, 2003 http://www.bioproducts-bioenergy.gov/default.asp.

\section{References for Assigning Chemical and Biochemical Pathways}

Ashford's Dictionary of Industrial Chemicals. $2^{\text {nd }}$ Edition. Wavelength Publications, Ltd., London, England. 2001 (8,360 entries with 7,970 structured diagrams).

Chemical Economics Handbook, Stanford Research Institute International, Palo Alto, CA, 2002 
Industrial Organic Chemistry. Klaus Weissermel and Hans-Jurgen Arpe, $3^{\text {rd }}$ Edition, VCH Publishers, NY (Wiley company) 1997.

The Merck Index: An Encyclopedia of Chemicals and Drugs. Merck \& Co., Inc. Rahway, NJ.

Kirk-Othmer Encyclopedia of Chemical Technology (online). Copyright ${ }^{\circledR} 2003$ by John Wiley \& Sons, Inc.

Ullmann's Encyclopedia of Industrial Chemistry (online). Copyright ${ }^{\circledR} 2003$ by Wiley-VCH Verlag GmbH \& Co. KgaA.

New Biocatalysts: Essential Tools for a Sustainable $21^{\text {st }}$ Century Chemical Industry. W. Scouten and G. Petersen. Copies available from W. Scouten at wscouten@utsa.edu and G. Petersen at gene Petersen@nrel.gov 


\section{REPORT DOCUMENTATION PAGE}

Form Approved

OMB NO. 0704-0188

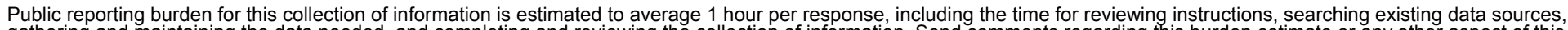

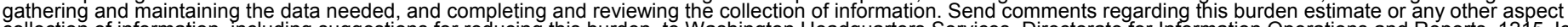

collection of information, including suggestions for reducing this burden, to Washington Headquarters Services, Directorate for Information Operations and Reports

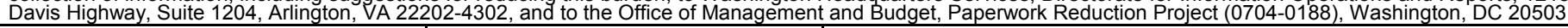
1. AGENCY USE ONLY (Leave blank)
2. REPORT DATE
3. REPORT TYPE AND DATES COVERED
Technical Report

4. TITLE AND SUBTITLE

Top Value Added Chemicals from Biomass: Volume 1-Results of Screening for Potential Candidates from Sugars and Synthesis Gas

6. $\operatorname{AUTHOR}(\mathrm{S})$

Todd Werpy and Gene Petersen, editors

7. PERFORMING ORGANIZATION NAME(S) AND ADDRESS(ES)

National Renewable Energy Laboratory

1617 Cole Blvd.

Golden, CO 80401-3393

5. FUNDING NUMBERS

BBC3.0110

9. SPONSORING/MONITORING AGENCY NAME(S) AND ADDRESS(ES)

National Renewable Energy Laboratory

1617 Cole Blvd.

Golden, CO 80401-3393

8. PERFORMING ORGANIZATION REPORT NUMBER

NREL/TP-510-35523

10. SPONSORING/MONITORING AGENCY REPORT NUMBER

DOE/GO-102004-1992

11. SUPPLEMENTARY NOTES

12a. DISTRIBUTION/AVAILABILITY STATEMENT

12b. DISTRIBUTION CODE

13. ABSTRACT (Maximum 200 words)

This report identifies twelve building block chemicals that can be produced from sugars via biological or chemical conversions. The twelve building blocks can be subsequently converted to a number of high-value bio-based chemicals or materials. Building block chemicals, as considered for this analysis, are molecules with multiple functional groups that possess the potential to be transformed into new families of useful molecules. The twelve sugar-based building blocks are 1,4-diacids (succinic, fumaric and malic), 2,5-furan dicarboxylic acid, 3-hydroxy propionic acid, aspartic acid, glucaric acid, glutamic acid, itaconic acid, levulinic acid, 3hydroxybutyrolactone, glycerol, sorbitol, and xylitol/arabinitol.

14. SUBJECT TERMS

15. NUMBER OF PAGES

biofuels; ethanol; fuels; chemicals; platform chemicals; syngas; synthesis gas; sugars; gasification; biomass; bioproducts; biorefineries

16. PRICE CODE

17. SECURITY CLASSIFICATION OF REPORT

Unclassified
18. SECURITY CLASSIFICATION OF THIS PAGE

Unclassified
19. SECURITY CLASSIFICATION OF ABSTRACT Unclassified
20. LIMITATION OF ABSTRACT

UL 


\section{A Strong Energy Portfolio for a Strong America}

Energy efficiency and clean, renewable energy will mean a stronger economy, a cleaner environment, and greater energy independence for America. Working with a wide array of state, community, industry, and university partners, the U.S. Department of Energy's Office of Energy Efficiency and Renewable Energy invests in a diverse portfolio of energy technologies.

For more information contact:

EERE Information Center

1-877-EERE-INF (1-877-337-3463)

www.eere.energy.go

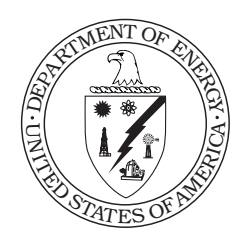

Produced for the U.S. Department of Energy (DOE)

by the National Renewable Energy Laboratory

a DOE national Laboratory

DOE/GO-102004-1992

August 2004

Printed with a renewable-source ink on paper containing at least $50 \%$ wastepaper,

including $20 \%$ postconsumer waste 